NIST GCR-99-779

\title{
Commercialization and Business Planning Guide for the Post-Award Period
}

Designed Especially for the Technology Entrepreneur

prepared for The Advanced Technology Program

National Institute of Standards and Technology

Technology Administration United States Department of Commerce

written by

Jenny C. Servo, Ph.D.

(716) 264-0510

(c) Dawnbreaker Press

September 1998 
Book design, figures, and tables by Jenny C. Servo, Ph.D.

Graphic design by Linda S. Sherman Design, Inc.

Previous Copyrights Knock their Socks Off: Making Winning Presentations to Investors (1993); Business Planning for Scientists and Engineers (1995) and Indicators of Commercial Potential (1996) by Dawnbreaker Press.

The authors have granted the U.S. Department of Commerce the right to publish this document for government purposes. No part of this book may be reproduced by anyone else, in any form, or by any means without express written consent of the author. 


\section{ACKNOWLEDGMENTS}

I would like to thank Rosalie Ruegg, Richard Spivack, and Robert Sienkiewicz for making it possible to develop this book. In particular, I would like to thank Rosalie for her vision, trust, and patience during the completion of this project. I would like to express my gratitude to Jeanne Powell for providing editorial insights during the final stages of the project. I would also like to thank the Principal Investigators of the ATP as well as SBIR and EM-funded companies with which we have worked. Your questions have led to the development of a book which I hope will be of unique assistance. 


\section{About the Advanced Technology Program (ATP)}

Started in 1990, the Advanced Technology Program (ATP) is a unique partnership between U.S. industry and government - one that is designed to advance the nation's competitiveness. ATP invests in industrial projects that, although highrisk, have the potential of yielding high payoffs for the nation. The program is industry-driven, with all projects envisioned, planned, and carried out by U.S. businesses. Both small and large companies, individually or as members of a joint venture, are eligible to participate in the program.

Companies become involved with the Advanced Technology Program through announced competitions. All competitions are open to single-company applicants (small, medium, and large firms), as well as to joint ventures. A rigorous peer-review process is used to evaluate proposals against publicly announced selection criteria. Awards are made for proposals that score high on technical, business, and national economic merit. From 1994 through 1998, most of ATP's funding was applied to focused program areas. Focused Program Competitions channeled support to a technology cluster of related projects. These clusters included:

D Adaptive Learning Systems

- Catalysis \& Biocatalysis Technologies

- Component-based Software

- Digital Data Storage

- Digital Video in Information Networks

- Information Infrastructure for Healthcare

- Manufacturing Composite Structures

- Materials Processing for Heavy Metals

- Microelectronics Manufacturing Infrastructure

- Motor Vehicle Manufacturing Technology

- Photonics Manufacturing

- Premium Power

- Selective-Membrane Platforms

- Technologies for the Integration of Manufacturing Applications

- Tissue Engineering

- Tools for DNA Diagnostics

- Vapor Compression Refrigeration Technology 
In each year from 1990 through 1998, ATP also held a General Competition; these annual competitions were open to all technologies. ATP is currently experimenting with alternative forms of competition.

ATP awards vary in size. Awards to individual companies are limited to $\$ 2$ million for a three-year period, and are limited to covering direct research and development costs only. Fortune $\mathbf{5 0 0}$ companies, or the equivalent, must provide at least 60 percent of total project costs. Irrespective of the size of the company, single applicants must cover their own indirect costs. This helps to assure their commitment and encourages faster commercialization. Awards to joint ventures can cover a period of up to five years. Joint ventures often take the form of a supplier chain, acting as a virtual corporation for purposes of this project. Joint ventures must provide more than $50 \%$ of the resources required to complete the project. Again, this is to assure a high level of commitment on the part of award recipients.

Historically, small businesses have fared well in this program. Of the 352 single applicant awards made between 1990 and 1998, 146 were made to small businesses. Of the 119 joint ventures funded during this same period, 39 were led by small businesses.

ATP funding is for research, not product development. As a result, companies whose ATP funding is ending must locate other sources of funds in order to make their technologies commercially successful. The objective of this guide is to assist ATP awardees during this post-award period. Our aim is to help companies deepen and refine their business plans, as well as attract funding to continue with the development and commercialization of their technologies. 


\section{SECTION 1}

BASIC CONCEPTS

\section{Table} of Contents - - A Financing Primer

- Commercialization Strategies

- Complex Strategies for Rich

Technology Platforms

- Licensing

- Teaming for Success

- Equity Investments

SECTION 2

PRESENTING YOUR OPPORTUNITIES

TO EQUITY INVESTORS

SECTION 3

THE WORKBOOK 


\section{Section 1}

\section{BAS I C CONCEPTS Meeting the Challenge}

A Financing Primer

Commercialization Strategies

Complex Strategies for Rich

Technology Platforms

Licensing

Teaming for Success

Equity Investments 


\section{Meeting the Challenge}

PRELUDE

WHAT MAKES THIS BOOK UNIQUE?

INTENDED AUDIENCE

CONCLUSION 


\section{Prelude}

The ATP Commercialization and Business Planning Guide for the Post-Award Period is a combination text and workbook, with one objective-to increase the likelihood of commercialization success by companies which receive funding through NIST's Advanced Technology Program (ATP). Meeting this objective is a tall order-and one which a book cannot accomplish on its own. To be of value, ATP awardees should use the Guide frequently. Pick it up when you first receive notification that you have won an ATP award, and continue to use it until your program is complete. "Using" the book doesn't imply merely dusting it off now and then for casual reading, but instead means working through the activities found in the workbook. The activities take time to complete and are intended to create cognitive dissonance. In other words, they are designed to help the technology entrepreneur develop new business habits—and part with misconceptions.

Most of you will need help "staying the course." I recommend that you seek assistance from members of your Board, staff, advisors, state service providers, and consultants. As long as the assistance is timely, affordable, motivating, and the result of solid experience, it does not matter who provides it. Advisors can help you with the sometimes-difficult task of putting these workbook activities on the front burner while at the same time keeping you focused on the demands of your core business. Advisors can also help ensure that that the quality of the work you accomplish is appropriate to the task with which you are faced.

\section{What Makes this Book Unique?}

During the past several years I have had the opportunity to view dozens of ATP-funded companies from various perspectives and to compare them with firms that receive funding through other Federal programs. It appears that ATPfunded firms face some unique problems and issues that arise as a consequence of the revolutionary nature of the technologies often funded by the Advanced Technology Program.

The ATP program is intended to promote U.S. competitiveness by supporting high-risk R\&D in technology areas where there is substantial potential for enhancing U.S. economic growth. ATP awards vary in size, are multi-year, require a funding match, and can be made to single companies or joint ventures, including

This book is intended for use ONLY during the postATP-award period. Be sure to refer to ATP documents for guidelines on proposal preparation. Do not use this book for that purpose.

Seek the involvement of an experienced, motivating mentor. A mentor can be a state service provider or a consultant. Or, you can find a mentor among:

- your Board of Directors

- your staff

- your Board of Advisors

ATP gathers feedback on business and economic developments from awardees on a quarterly basis, through the ATP Business Reporting System. 
UNIQUE ISSUES:

- many suitors for "hot" technology

- more complex commercialization strategies required

- rich technology platform makes focus a challenge

- more sophisticated planning

- more rapid learning curve both large and small firms. ATP succeeds in attracting firms that work in advanced technology areas. As a result, ATP awardees often have unique needs. For example:

D Some of the technologies funded by ATP are "hot." Therefore, once an ATP award is announced, a small company may suddenly find itself flooded with inquiries and suitors. On the surface, this would appear to be an enviable situation. However, there is a downside: the company is suddenly thrust into the position of having to make quick, far-reaching decisions about partners, commercialization strategies, and valuation.

D A related problem is that many small, innovative companies do not yet have the basis for understanding how much money or effort it truly takes to bring a product to market. As a result, they either avoid or rush into arrangements, without understanding the full implication of their actions.

- Technologies funded by ATP frequently affect multiple industries. As a consequence, an ATP awardee needs to contemplate the implementation of a far more complex "constellation of strategies" to exploit his/her company's particular technology. Again, this requires the awardee to think quickly-and strategically-across diverse industries. This is difficult for even the most skilled businessmen and businesswomen to do. Once a multi-faceted strategy has been mapped out, the awardee must wisely select the initial focal point of his/her efforts. When confronted with many options, it is easy to inadvertently squander precious time, energy, and resources.

D Perhaps as a consequence of the problems faced by awardees early on, many ATP-funded start-up companies engage in private placements as a means of financing early-stage growth. Different financing options require different types of documentation. Often there is confusion about the differences in style and purpose of business plans used externally with debt and equity financing, and the prospectus and private placement memoranda used with Initial Public Offerings (IPOs) and private placements.

D The prospect of rapid growth requires that a company's founder spend more time planning, and that he or she remain focused, so as to steer the course of a rapidly moving enterprise. From a human resource perspective, rapid expansion is much like an uncontrolled chemical reaction: highly unpredictable. Growth, therefore, requires a mixture of diplomacy, vision, energy, and flexibility on the part of the founder. 
Companies that receive ATP funding appear to face a sharper and more rapid learning curve than other companies do. As a consequence, the Guide places a special emphasis on the special issues raised above, at the same time that it attempts to provide some of the fundamental business knowledge that any technology entrepreneur must master. Throughout the Guide, reference is made to unique considerations in biotechnology, information technologies, and other advanced fields.

This ATP Guide is divided into three sections. Section 1 contains seven chapters and provides the reader with a cognitive framework in which various commercialization issues can be considered. Section 2 is a tutorial that describes how to make a winning presentation to equity investors and/or potential strategic allies. Section 3 is a workbook of activities which can be completed selectively by the ATP awardee.

Section 1 opens with this prelude. Following this introductory chapter, it provides a Primer to Financing Options, intended to introduce the reader to the domain of available options. A simple typology of commercialization strategies is presented in Chapter 3. With the framework in place, the reader is then introduced in Chapter 4 to the complexities posed by having a rich technology platform. In such situations one must consider the myriad of ways in which to best exploit the technology. The result is a constellation of strategies which may be applied to various upstream and downstream applications. Finally, Chapters 5 - 7 provide a more in-depth treatment of three financing options.

Section 2 provides a sample presentation to equity investors. It is divided into four parts: Company/Technology/Product, Market Assessment, Goals and Objectives, and Challenges/Requirements/Opportunities.

Once the reader understands the financing options available, he or she needs to prepare to meet the demands of the following tasks: (1) select the best strategy; (2) convey the opportunity to others; (3) understand the value of an opportunity as well as the expenses associated with its commercialization; (4) make a logical case for investment by a strategic ally/investor; (5) engage in successful negotiations with appropriate partners or investors; and (6) successfully guide the growth of his or her firm. For most small companies, success in these endeavors requires increased business acumen. Section 3 of the Guide is designed to sharpen these business skills.

\section{Intended Audience}

This book was written expressly for both ATP awardees and their advisors. It is directed at the technology entrepreneur. Much of the advanced information contained in Section 1, while new for many ATP awardees, should constitute the

This book was written for both ATP awardees and their advisors to use during the post-ATP-award period. However, other companies will also find the materials useful. 
Lack of knowledge, traditional biases, an overwhelming amount of work, and high expectations are often a deadly combination. knowledge and experience base of a skilled advisor. Thus, Section 1 is designed to impart both basic and more advanced information to awardees, with respect to funding and partnering options.

Section 2 provides guidance on a method for succinctly representing an awardee's opportunity in an oral presentation to private sector investors.

Section 3 has a different objective. It outlines a variety of activities which the ATP awardees can address on their own. At the same time, the awardee's advisor can selectively recommend activities from Section 3 once he or she has determined the weak points in an ATP firm's preparation.

The reason for including a workbook in this Guide merits more than passing mention. When confronted with inquiries from potential investors and allies, pressures to grow rapidly, and the need to make quick and profound judgments, an entrepreneur may be inclined to turn such responsibilities over to a consultant. This is not the appropriate course of action, however. A technology entrepreneur MUST be actively involved with all such decisions. Just as a product concept evolves and changes over time, so, too, must the business acumen of the technology entrepreneur. Failure to expand one's understanding of the business will sooner or later have profound - and usually negative-consequences for the company. Such consequences include: (1) pursuing less promising product concepts; (2) missing the market window of opportunity; (3) making poor hiring decisions; (4) picking the wrong partners; (5) harboring unrealistic expectations; (6) overextending one's finances; (7) being blindsided by a competitor's actions; and (8) failing to negotiate a win-win relationship with investors and partners. Although preparation is not an antidote to all of these problems, one stands a far better chance of responding appropriately if well prepared.

The solution to these problems is not merely a function of money. Without preparation, money is insufficient. Why am I so convinced that money is not enough? In the mid-1980's, I worked as a consultant to a Fortune 500 company with an "intrapreneuring" program. One of my roles was to assess the training needs of these intrapreneurs and to outline some of the problems of the fledgling ventures-a unique opportunity.

The premise behind the intrapreneuring experiments of the 1980's was the belief that if one could combine entrepreneurial vision and zeal with the resources of a large company, success could more readily be realized. Therefore, technology entrepreneurs from within a company-intrapreneurs-were sent to skunk works or corporate incubators and provided with whatever resources they required. Unfortunately, the expectations-at least for this company's intrapreneuring program-were not realized. While there were many reasons, the key seemed to be the failure of the technology entrepreneurs to adequately increase their business acumen. Lack of new knowledge and traditional biases, combined with an overwhelming amount of work and high expectations, is a deadly combination.

$M E E T I N G$ T HE C H A L L N GE

(c) DAWNBREAKER PRESS, 1998 
The good news is that most scientists and engineers can learn the business skills needed to be successful. But training must be flexible, experienced professionals must provide it, and it must offer a structure that makes the designated activities a priority. We have used this approach with hundreds of technology entrepreneurs and have demonstrated its effectiveness.

\section{How to Use This Book}

The objective of this workbook is to provide you, the ATP awardee, with a way of increasing your business know-how at a speed commensurate with the challenges ahead. New information that results from the workbook activities should be synthesized and compiled into a set of useful documents, all of which become part of your commercialization toolkit. Recognizing that it is always difficult to add planning to

Commercialization Toolkit ${ }^{T m}$

- Strategic plan

- Licensing package

- Business plan

- Presentation materials

\section{When to Use This Book}

In this workbook, several assumptions have been made regarding when you will require certain information and tools. Starting with a proposed schedule should provide you with a clear idea of how to proceed. All companies and situations differ, however, and the proposed schedule may not meet your exact needs. If this is the case, make appropriate adjustments.

The figure on the next page provides an overview as to when certain documents and activities should be completed. It is important to note that this book is intended for use by ATP firms during the post-ATP-award period. During the preparation of an ATP proposal, companies are expected to include a preliminary business plan with their proposal. Be sure to consult ONLY ATP proposal preparation documents for guidelines on how to produce that plan. Do NOT use the Guide for that purpose. The Guide is intended for use ONLY in the post-award period-that is, during the period following the announcement that a company has received an ATP award. The purpose of this guide is to help ATP awardees to "flesh-out" and enhance commercialization planning activities initiated at an earlier time.

Most importantly, planning requires commitment. Unless you decide to commit the time and resources required for thoughtful planning, you might be caught off guard when opportunities and challenges present themselves. 
Suggested schedule for completing various activities.
FIGURE II-2:

SCHEDULE FOR DEVELOPING A COMMERCIALIZATION TOOLKIT

READ

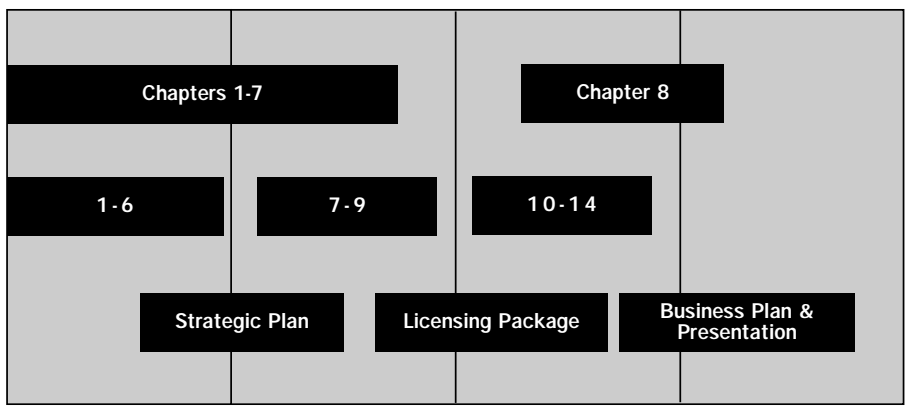

Announcement Start

6 months

12 months

TIME LINE

\section{Conclusion}

The purpose of the ATP Commercialization and Business Planning Guide is to provide assistance to new ATP awardees. The book is divided into three sections:

- Section 1 offers an overview of financing options, with detailed information on licensing, corporate partnering, and equity investment.

- Section 2 provides guidance on how to make a winning presentation to potential equity investors, strategic allies, and/or potential licensees.

- Section 3 is a workbook to be used by the technology entrepreneur on his or her own or with the guidance of an experienced advisor to develop specific components of a business plan.

For maximum benefit, you are urged to seek the involvement of an experienced and motivating mentor or advisor. Working together through the various workbook activities, you can synthesize and incorporate the material into a variety of documents-documents that will become part of your Commercialization Toolkit ${ }^{\mathrm{TM}}$. Suggested outlines for the various documents that you are likely to need in the commercialization of your technology are included at the end of various chapters in Section 1. These include:

D A strategic plan

- A licensing package

- A business plan

- Presentation materials

The quotation on the following page is fictitious but offers insights into the types of challenges and changes that are commonly experienced when commercializing a rich technology platform. 


\section{One Company's Perspective}

When TechWest applied for ATP funds, we were already a going concern with equity investment from two private individuals. We sought ATP funding as a means to develop novel methods of production which would allow us to meet perceived market need for our product.

Upon receiving the ATP award, our immediate challenge was to raise the additional funding required to meet our overall business objectives. This took most of my time, but we were successful in realizing our short-term financing goals.

Three years have elapsed since first receiving our ATP award. During this time, my focus has shifted from inside management to customer-focused activities. I have added staff to handle more of the day-to-day operations. This shift in role was easier for me than for some founders, as my background is more on the business, as opposed to the scientific, side.

Customer interaction was vital to our company's growth and surfaced new opportunities which ultimately resulted in a shift away from our initial product concept to a new focus. TechWest has always been open to investigating new commercialization strategies which would result in the creation of greater value.

As a consequence of this new focus, many changes were required in our firm. The biggest challenge was changing the culture of the company. We had to shift from being a relatively small, scientific, low-volume operation to a production-oriented, ongoing business. This required a change in emphasis from R\&D to engineering. Some personnel could not make this shift and are no longer with the company. This required management action and decisions.

Currently, we also outsource some significant work, and are extremely careful about protecting our technological base while outsourcing. Outsourcing, by the way, was not a part of our original intent.

To date, approximately $\$ 20$ million of private sector financing has been invested in the firm, from two sources: our initial private investors, who made multiple rounds of financing, and a customer who made a minority equity investment. My advice for other ATP firms: be persistent in seeking financing — do not take "no" for an answer. Have an active and interested Board. Don't be reluctant to change focus when you can justify that another direction presents a better business opportunity, and be prepared to make the necessary cultural shifts. 


\section{A Financing Primer}

AdVANCED ORGANIZER

AN EXPENSIVE ENDEAVOR

WHAT DO YOU WANT TO BE

WHEN YOU GROW UP?

SWEAT EQUITY

SCIENCE-FOR-HIRE

DEBT FINANCING

EQUITY FINANCING

AVAILABILITY OF EQUITY

FINANCING

STAGES OF EQUITY FINANCING

WHAT DO EQUITY INVESTORS

LOOK FOR?

WHAT DO EQUITY INVESTORS

WANT IN RETURN?

CONCLUSION 


\section{Advanced Organizer ${ }^{1}$}

The purpose of this chapter is to introduce the five broad areas of financing available to technology entrepreneurs seeking to capitalize the growth of their firm: sweat equity, publicly-funded R\&D programs, debt, equity, and profit. Not all forms of financing are available to companies at the same time. Debt financing becomes available when the company has sufficient collateral. Equity investments become increasingly available as technology and market risks are decreased. From a financing perspective, the most difficult time for technology entrepreneurs is during the early R\&D phase, when the private sector is loathe to make investments. Sweat equity and R\&D partnerships enable such companies to develop new technology and position them to involve private sector capital once R\&D risk has been decreased.

\section{An Expensive Endeavor}

Commercialization is an expensive endeavor, and advanced technology firms have a voracious appetite for money. As a result, technology entrepreneurs must thoroughly familiarize themselves with different funding mechanisms. The scientist shouldn't approach financing by asking, "which type of funding do I prefer?" but instead should assume that at different points in the life cycle of their business they may need to use different types of financing to nurture and sustain their business. The questions to consider are as follows:

(1) How do the available financing methods vary as a function of the stage of technology/product development?

(2) In what sequence should different financing options be considered?

(3) How can various financing options be kept available as commitments to other creditors increase?

(4) How do personal goals and aspirations interact with the available alternatives?

Why should financing methods be considered prior to the development of a business plan? The reason is simple: financing is a key variable in shaping the planning process. It plays a part in every strategic consideration one makes.

In this chapter we will briefly introduce alternative methods of financing.

ATP awardees will have already made certain choices regarding financing strategies. This chapter pinpoints your location on the financing roadmap, while Chapters 3-6 provide detailed insight into strategies you may wish to pursue.

${ }^{1}$ This chapter is an updated version of Chapter 13 from Business Planning for Scientists and Engineers. 
Without federally funded

$R \& D$ programs, many small advanced technology programs would not survive. Private sector investors prefer to wait until technology and market risks are reduced before investing their funds.
Generally speaking, there are five broad categories of financing that may be used to capitalize a firm: sweat equity, publicly funded R\&D programs, debt, equity, and profit. The order of the list reflects the general sequence in which start-ups tend to utilize them. Larger firms use the last five financing categories selectively.

Each of these broad categories will be discussed briefly, and then elaborated upon later in this chapter.

FIGURE 2-1: METHODS FOR FINANCING THE SMALL HIGH-TECH FIRM

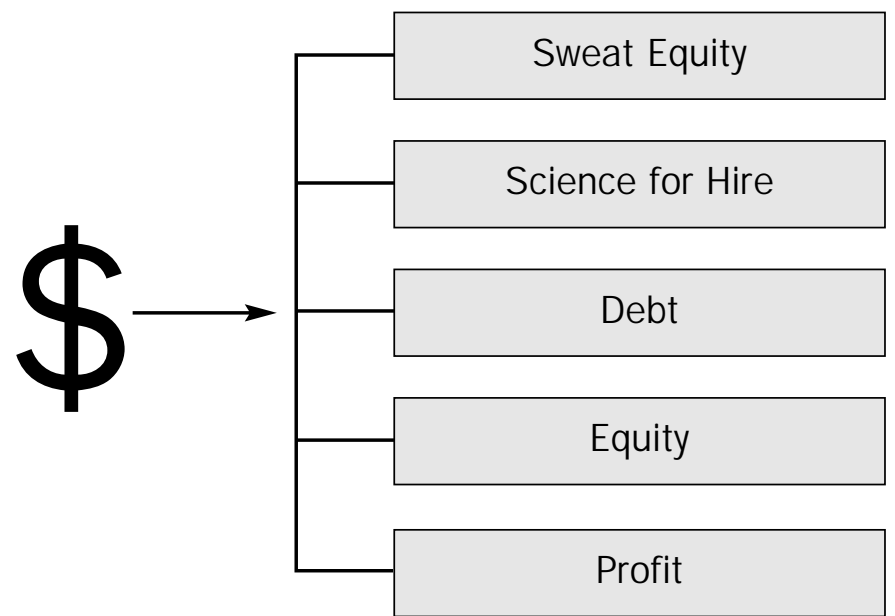

The term "sweat equity" implies the use of uncompensated time and the lending of one's own resources to nourish the business during its earliest phases. Periodically, when cash flow wanes, it is not uncommon for the founders of a company to delay compensation for their work until a later time. Thus, the use of sweat equity is a method that many technology entrepreneurs use to give birth to their business as well as sustain it during periods of financial difficulty.

Many technology entrepreneurs support the preliminary development of a technology through participation in publicly funded R\&D programs. Public funding sources include state programs and Federal arrangements such as the SBIR program and the ATP. A variety of contractual arrangements are available through Federal mission agencies, as well as through state programs, often aligned with Federal initiatives.

Debt financing refers to the borrowing of money with the promise of full repayment of the principal with interest. A variety of vehicles can be used for debt financing, including secured and unsecured loans, promissory notes, bonds, leases, supplier credit, and other debentures. Debt gives its owner the right to be repaid the investment with interest irrespective of the success or failure of the business venture. Debt financing can be considered when an individual or a company has sufficient collateral. 
Equity financing is speculative in nature, as the financier is not guaranteed repayment of the money invested. This is high-risk capital and therefore commands subordinate to debt financing. hefty compensation-compensation that is commensurate with the degree of risk taken. Vehicles used for equity financing include the receipt of stock through the investment of venture capital, business angels, and investment bankers. The return on an equity investment is dependent upon the success of the business. One reaps a large financial reward if the company is successful and no reward if the company fails. Equity financing is subordinate to debt financing, which means that in the case of bankruptcy, debt financing arrangements must be honored before any payment to equity investors may be made. Business angels are recognized as providing the most lenient terms and for making smaller equity investments than entities in the smaller, institutional investor market.

When making decisions regarding the capitalization of a firm with debt or equity, many things need to be considered. The preliminary choice of debt or equity has IRS implications, as taxation is handled differently with these two methods of financing. Interest paid on the repayment of a debt is tax deductible. However, dividends paid on equity investment must be paid with after-tax dollars. This debt-equity decision also raises control issues. For example, the most common evidence of an equity investment is the issuance of common stock. The owners of common stock have voting rights that give them a say in the management of your company. Debt can also be changed to equity. A good discussion of these two methods of capitalization can be found in A Desk Book for Setting Up a Closely Held Corporation, by Robert Hess (1985).

As a company grows and becomes successful, profit is accumulated-profit that can be used to fund various business needs and decrease reliance on external sources of capital.

\section{What Do You Want to be When You Grow Up?}

Exactly which sources of financing are available to a firm become clear after reflecting on a company's vision. Three prototypical visions exist (Hisrich \& Peters, 1989), as follows:

D The life-style firm

- The high-potential venture

- The foundation company 
TABLE 2 - 1: DIFFERENT VISIONS FOR THE FUTURE

\begin{tabular}{|l|c|c|c|c|}
\hline & Revenue & \#Employees & Purpose & Private/ Public \\
\hline Life-Style & $\$ 2$ million & $30-40$ & support owners & Private \\
\hline Foundation & $\$ 10-30$ million & $40-400$ & start new industry & Private \\
\hline High-P otential & $\$ 20-30$ million & 500 & growth \& value & Go public \\
\hline
\end{tabular}

Although it is important to recognize if yours is a lifestyle company, it is not recommended that you label your company as such when talking with external audiences.

Different visions:

- Life-style company

- Foundation company

- High-potential venture
If your intent is to develop a company that will remain fairly small, allow you to pursue your technical interests, and support you and a few others, yours is aptly described as a life-style company. Such a company sees itself as having revenues of \$2-3 million within five years and employing 30-40 people at the most. Such a company is NOT of interest to the venture capital or investment banker community, as their purpose in making an investment is to realize a large return through involvement with fast growth companies. You may find local business angels to be amenable to small investments, however, if you have a good business plan and a good team. Life-style firms are best served by pursuing licensing arrangements, strategic alliances, debt financing, and growth from reinvestment of profit.

At the other extreme are high-potential ventures. Such firms envision revenues in excess of \$20-30 million in five to seven years, and anticipate going public as a means of cashing out and creating value for their investors. A company founder who selects this path must anticipate that he or she will be stretched to the limits of their capabilities; will need to involve a multi-disciplinary team early in the company's life; will need to become facile with different financing options; and will need to master coalition building. As if that is not enough, technology entrepreneurs who aspire to create a high-potential venture must also recognize that that they may have to step aside when the company goes public if they are unable or unwilling to redirect energies to investor relations upon becoming a public firm.

If you are looking to be an industry leader and to grow a company hard and fast, then you are developing a high-potential venture. All forms of financing will be open to you at different points in the development of your company. The Advanced Technology Program funds companies with a bold vision for growth and impact.

The foundation company lies somewhere between these two extremes. The founder has both the technology and the desire to be an industry leader, yet wants to grow the company in a less meteoric fashion. The technology entrepreneur is not attached to having the firm remain small, and sees the company developing 
capabilities in all business functions, as is appropriate. The management team is often more conservative with respect to its involvement of equity investors, and chooses to have the company remain privately held. The desire to remain privately held differentiates the high-potential ventures from the foundation companies.

A more detailed treatment of the five major categories for financing a business follows.

\section{Sweat Equity}

The first type of financing commonly used by any entrepreneur is sweat equity. How the issue of sweat equity is handled depends upon your vision for the future. If your goal is to develop a high-potential venture, be forewarned that equity investors putting cash on the line will not be impressed by your investment of time and passion. As far as equity investors are concerned, if you have little capital invested in your company, you are not heavily committed. Because your financial commitment may be represented in the form of collateral as well as cash, keep good records on the equipment, real estate, and other hard assets that can be counted as collateral applied to this endeavor.

If you defer compensation during periods of poor cash flow, be sure to keep good records regarding the cash owed to you by the corporation and have formal agreements with the company regarding terms of repayment. In addition, talk with your accountant about what is involved with converting debt to equity in the event that you wish to change the terms of repayment (Blechman and Levinson, 1991).

Another important factor to be attentive to when using sweat equity is the question of how to handle intellectual property developed with your own resources prior to forming your company. If you have clear title to such intangible assets, and if they provide the foundation for your firm, formalize the relationship of those assets with your company. This can be done either by licensing rights to your firm or by selling the intellectual property to the firm. A useful resource to consult for ideas is Write Your Own Business Contracts (Barrett, 1990).

Sweat equity is invested not only by founders but also sometimes by service providers. It is not uncommon for founders to seek the assistance of service providers on a speculative basis. When cash is lean, entrepreneurs often seek patent attorneys, market research firms, business consultants, and other recruits to the management team who are willing to become involved "on spec" (speculation). It is important that you keep in mind that such service providers are taking a big risk and are, therefore, likely to ask for a substantial return. Be sure to have contractual arrangements with every party who becomes involved with your company in this fashion. Be aware that, if you give away a substantial portion of your company at the outset, you will have little to bargain with later on when more cash is needed. Be

At the "possibility" stage, a young company requires the passion and enthusiasm of the founder and a few others involved in the firm. These individuals form a special relationship as a result of their strong personal commitment.

Protect your intellectual property rights.

Owner's equity refers to the initial capitalization of a company by one or more founders. 
FIGURE 2 - 2: ROADMAP OF FINANCING OPTIONS

\section{Most ATP}

awardees are at

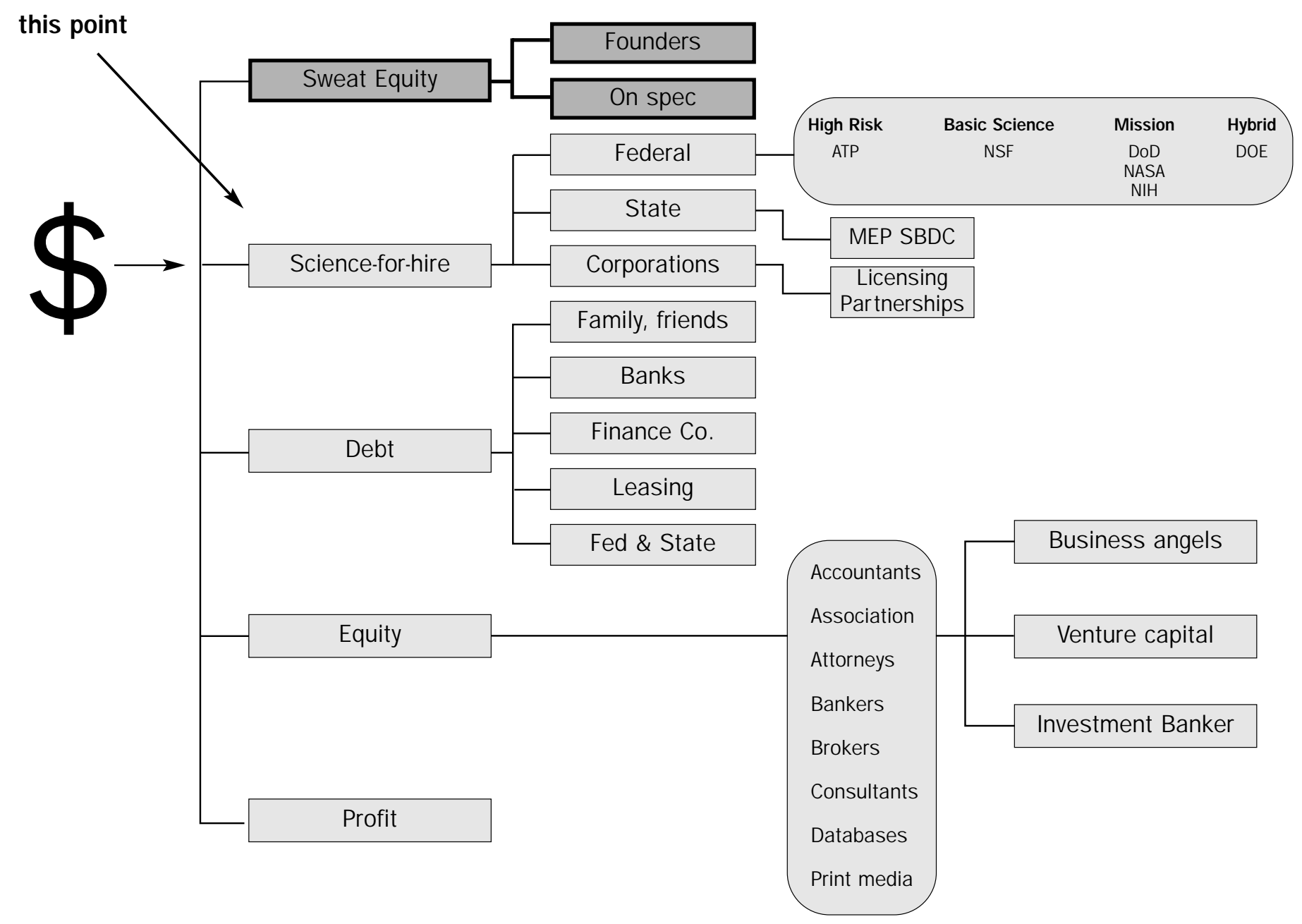




\section{R\&D Partnerships}

A financing mechanism sought by many advanced technology firms is a Research and Development partnership. Such arrangements allow the entrepreneur to develop intellectual property that can be commercialized through his/her company while working with other organizations. In various ways, Federal, state, and private sources provide such opportunities. The Advanced Technology Program (ATP) is unique in sharing the costs of high-risk technology that result in general economic growth. The Small Business Innovation Research Program (SBIR) provides funding to small businesses with innovative technologies that can solve problems of specific interest to the Federal government. Many of the mission agencies-including the National Aeronautics and Space Administration (NASA), the Department of Defense (DoD), the Department of Energy (DoE), and the National Institutes of Health (NIH) - also contract with technology firms to develop products and services the Agencies wish to buy. The National Science Foundation (NSF), in contrast, has historically focused on making grants to academic institutions for basic research.

FIGURE 2 - 3: RESEARCH AND DEVELOPMENT PARTNERSHIPS

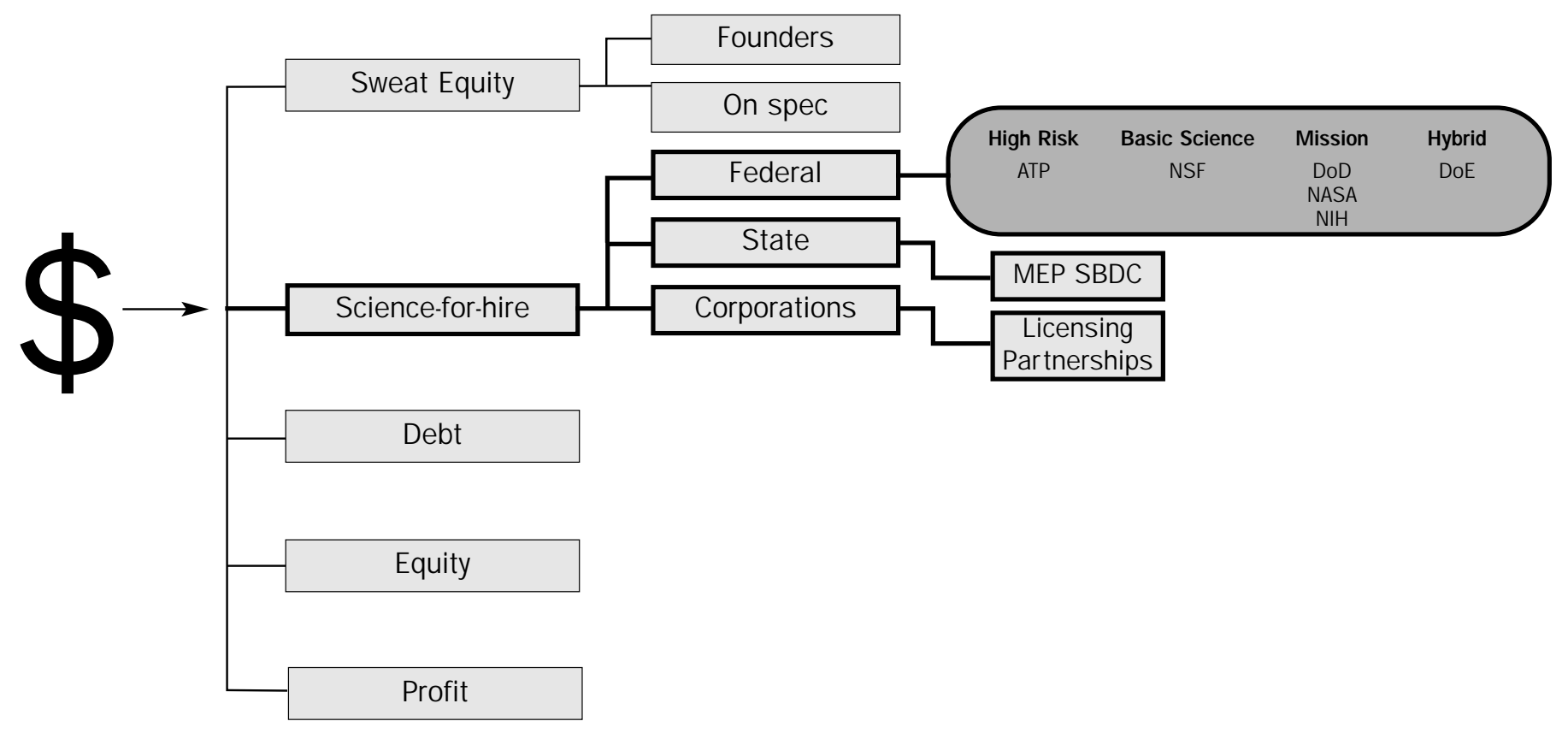


The various $R \& D$ partnership programs conducted by the Federal government and buttressed by state programs provide an excellent and essential bridge between the sweat and owner's equity invested by the founders, and the private sector investments made by lending institutions and equity investors.
Most federally funded R\&D programs allow the entrepreneur to retain rights to the intellectual property created while performing the work funded in whole or in part by the Agency. It is the right to retain ownership that provides incentives for the entrepreneur and provides small businesses with the opportunity to commercialize. The government typically receives a non-exclusive license to the technology for government purposes.

Many states also support federal initiatives through services offered by Manufacturing Extension Programs or Small Business Development Centers.

Another source of funding for Research and Development partnerships is large corporations. The development and exploitation of a rich technology platform require considerable resources, and Federal Research and Development programs will likely only take an awardee part way through the R\&D process. In most cases, the technology entrepreneur must team with other entities in order to commercialize the technology. Licensing and Research and Development partnerships provide excellent opportunities for small companies to extend their effectiveness in bringing technology to market. Licensing will be discussed in detail in Chapter 5, and Research and Development partnerships will be explored in Chapter 6.

Research and Development partnerships can be extremely advantageous to small advanced technology firms, especially if the entrepreneur views this work as an opportunity to develop intellectual property that can be used as the foundation for his or her business. With such arrangements, the money does not have to be repaid, nor equity parted with. If performing Research and Development for or in partnership with, the Federal government, the government will receive a nonexclusive license for government purposes on intellectual property created. However, you will retain all other rights.

\section{Debt Financing}

While an R\&D Partnership method of capitalization can be highly beneficial, it will only take you so far. At various times in the evolution of your firm, you will need to consider debt financing. As mentioned earlier, debt financing gives its owner (the lender) the right to be repaid the investment with interest irrespective of the success or failure of your business.

When should you consider such financing?

D when you need assistance with cash flow while performing on Research and Development contracts;

D when you need working capital and you wish to retain as much equity as possible in your firm;

D when making large purchases of equipment, buildings, or real estate;

D when planning acquisitions; or

D when you wish to refinance existing debt 
There are various debt instruments and various organizations from which you can seek debt financing. Typical debt instruments include:

- Promissory notes

- Secured \& unsecured loans

- Lines of credit

- Factoring

Debt financing can be obtained from family and friends, banks, finance companies, leasing companies, brokerage houses, mutual funds, and state and Federal government agencies. In most instances a short-term loan is considered to be less than one year in duration, whereas a long-term loan is usually one made over a period of one to five years.

FIGURE 2-4: SOURCES OF DEBT FINANCING

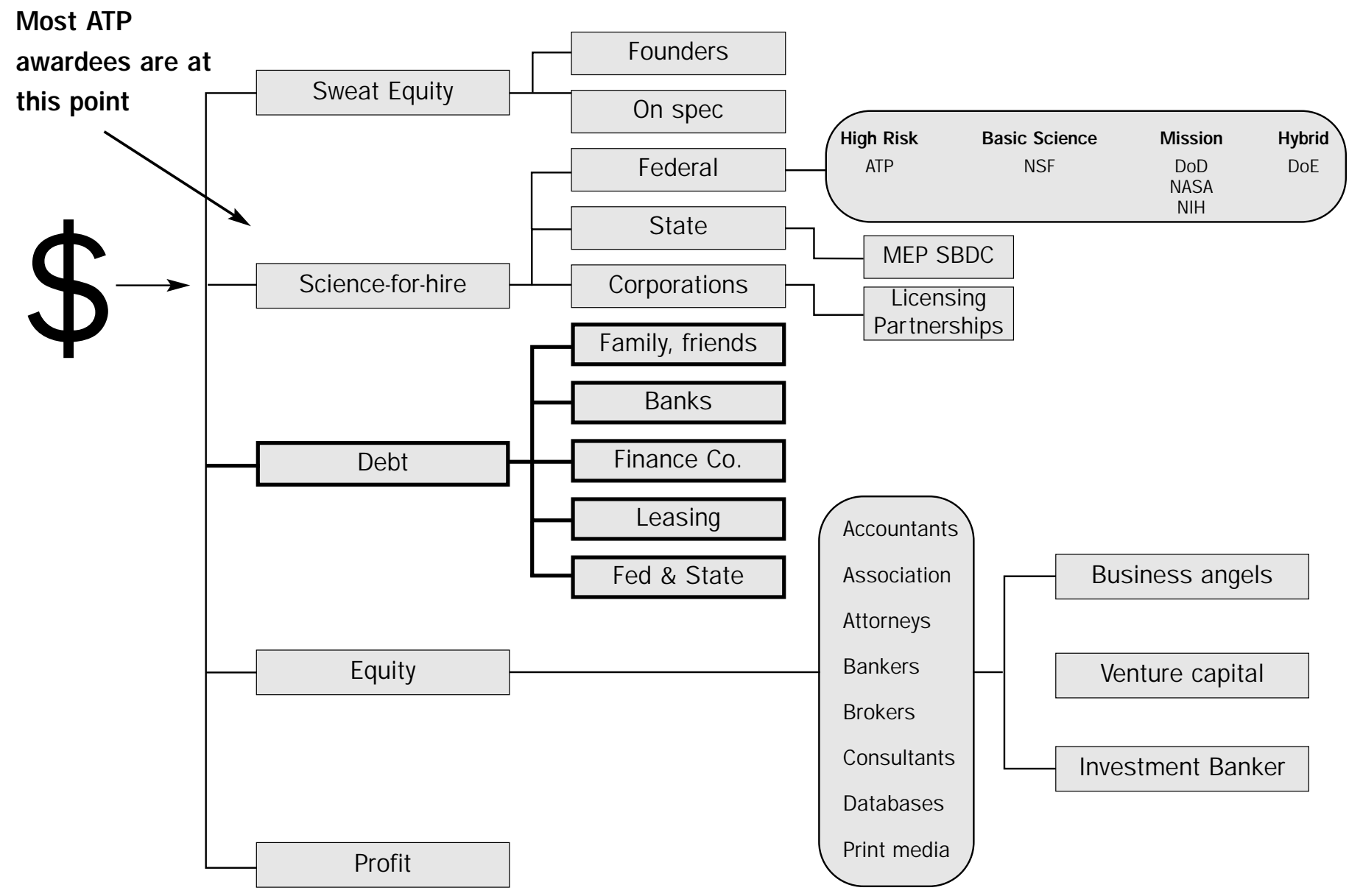




\section{Borrowing from Friends and Family}

When borrowing from family and friends, both you and they take a risk. Important relationships may be damaged if you fail to honor your debt. Also, such lenders may assume that they own part of your business and try to act as equity investors meddling in the daily activities of your firm. Such problems can be avoided, however. In a brief article entitled "How to Borrow from Family and Friends" (Inc, July 1995), one entrepreneur describes how he successfully used this source of financing during the first year of his start-up. He first formalized the relationship with each lender by drafting Promissory Notes due within a specified time period. An option was added to each Note allowing him to roll the loan over as necessary; in addition, an interest rate was agreed to. The entrepreneur's intent was to view these loans as short-term and shift to bank debt within a year. He did this successfully while maintaining good relationships with all involved.

Another important item to note is that the IRS may examine such arrangements to see if they are truly debt or equity financing. Be sure to discuss this matter with your accountant and consult Hess's book for ideas. A good Promissory Note should clearly indicate the name of the person to whom debt is owed, the maturity date, who is obligated to pay the debt, the interest due, the right to enforce payment, and the status of the debt relative to other forms of financing.

\section{Borrowing from Banks}

Banks are becoming more interested in attracting and retaining small businesses as clients. This is because many large businesses are going elsewhere to meet their capitalization needs, since it is easier for them to obtain equity capital and funds from institutional debt markets. However, the problem for banks is that there is also a good deal of competition for small business from commercial finance and assetbased-lending firms, leasing companies, brokerage houses, mutual funds, and microenterprise lending institutions. (Small business is defined by banks as companies with revenues less than $\$ 5,000,000$.)

Once your company has developed sufficient history, you may wish to approach commercial banks again for a loan or a line of credit for your business. Most resources indicate that in order to make this an option, you should develop a relationship with your banker. You need to educate your banker regarding your business, your business plan, and your annual sales projections. Personal credibility develops trust.

As was mentioned earlier, there are many sources that one can approach for debt financing besides banks. In all cases, before approaching a lender, one should take stock of the assets that they have and try to match these assets with the appropriate type of lender to approach. An excellent discussion of how to proceed with 
this is found in Guerrilla Financing: Alternative Techniques to Finance Any Small Business, by Blechman and Levinson (1991). Most lenders require collateral for loans, that is, something that can be sold to reimburse them for their loan if you default. One form of collateral that is interesting to explore is receivables.

\section{Receivable-Lending Institutions and Factors}

When a company has a receivable, such as a contract, back order, purchase order, or work in progress, it can consider approaching a receivable-lending institution or a "factor" (see explanation of factors, below) for financing. A receivable-lending institution is often a division of a commercial bank that uses receivables as collateral in providing a loan. The money is usually provided as a line of credit for up to 60 days. The amount advanced is a percentage of the receivable and varies with the size of the invoice. Interest rates on such arrangements are typically higher than on traditional secured loans (Garner et al., 1994).

A closely related form of debt financing to cover short-term needs for working capital is a revolving line of credit. Working capital loans of this nature are usually short term (less than a year) and can be secured or unsecured. If the company is in the start-up mode, the founders may need to pledge the use of personal assets for collateral. Unsecured loans are a possibility for companies with outstanding credit histories.

Start-up companies will again have a tough time here, as such institutions will look at the financial history of your company and the creditworthiness of your receivables. Certainly, if you are using a contract with the Federal Government as a receivable, the customer is creditworthy. However, if you are a brand new start-up, your company will not have any financial history.

Another source that can be approached with receivables is an entity referred to as a factor. Finance companies often serve as factors. They operate in a very different fashion than banks. According to Blechman and Levinson, start-ups and companies with poor credit would find greater receptivity from a factor than they might from a receivable-lending institution. The fees charged by factors vary and can be hefty. Finance companies do not have the same regulations placed upon them as banks, and thus are willing to take somewhat more risk than a bank. For a good discussion of the pros and cons of factoring and receivable-lending institutions, consult Guerrilla Financing by Blechman and Levinson and the Ernst \& Young Guide to Financing for Growth by Garner et al. 


\section{Leasing}

Before making a decision to purchase equipment, land, buildings, or any other tangible asset, consider leasing. This will require that you talk with your accountant about the pros and cons of such decisions, including the impact leasing will have on your balance sheet. Why your balance sheet? Scientists use calibration devices all the time, and so do investors. All sources of capitalization look at the health of your business by examining financial ratios that are based on either your Balance Sheet and/or your Income \& Expense Statement.

The Balance Sheet is a snapshot of your business at a specific point in time. It is the only financial record in which you will see the phrases "assets" (A), "liabilities" (L), and "shareholder equity" (E). A formula is applied to demonstrate the relationships among these items:

\section{Assets = Liabilities + Shareholder's Equity}

Tangible assets include items such as Cash, Accounts Receivable, Loans to Stockholders, Land, Equipment, Real Estate, and Pre-Paid Expenses. Liabilities include items such as Accounts Payable, Loans from Stockholders, Retainers, and Advances. The decision to purchase or lease a tangible item affects whether or not it is considered an asset on your balance sheet and will affect the ratios or measuring devices that investors examine. Leasing is referred to as "off-balance-sheet" financing, because it does not appear as an asset on the balance sheet, and because only the payments that become due show as a liability. Therefore, if you know that you are going to need a loan, you will want to make your balance sheet look as good as possible. A good accountant can advise you how the lease/buy decision will affect your balance sheet.

There are, of course, other more obvious reasons to lease: (1) if you want to avoid a large cash outlay, (2) if you don't wish to purchase equipment which may become obsolete, or (3) if your production volumes favor leasing over buying, or vice versa.

In a lease scenario, the entity providing the lease is referred to as the lessor of the property. The entity obtaining the lease is referred to as the lessee. There are two broad categories of leases: traditional and modified. Other types of leasing arrangements-referred to as venture leases, master leasing real estate, sale and leaseback financing-are discussed in detail in the texts by Garner and Blechman \& Levinson referenced previously. 


\section{Supplier Credit}

You may not consider it debt financing, but companies with good credit ratings benefit from the 15- to 30-day terms their suppliers provide at $0 \%$ interest. If you can speed up the rate at which your customers pay you, you can minimize the need for other interest-bearing loans to pay your suppliers. You can speed up the rate at which your receivables are paid by billing at the time services are rendered (instead of waiting till a specific time each month) or by providing customers with an incentive to pay quickly. Other good money management techniques include requesting progress payments and up-front mobilization fees.

\section{Federal and State Programs}

A wide variety of programs provide debt financing to small businesses at both the Federal and State levels. The incentive is always new job creation. Companies with 500 or fewer employees (the SBA's definition of a small business) are important drivers of the economy. Information on these programs is available from your local Small Business Administration office, an SBDC (Small Business Development Center), or your local Chamber of Commerce.

\section{Equity Financing}

The phrase "equity financing" refers to a class of investments that share a number of common features. First, from the investor's perspective, equity financing is speculative. With all forms of equity investments, no guarantees exist that investors will be repaid. Realizing a return on such an investment is dependent upon the success of your business. An investor reaps a large financial reward if your company is successful and no reward if your company fails. For this reason, equity investors command hefty compensation commensurate with their risk.

Another feature that equity investors share is ownership in your business. Equity implies the exchange of stock in return for money-as it is through ownership that the investor will profit from the success of your firm. For this reason, founders must decide if they are willing to share the control, as well as the risks and rewards of their company.

Sources of equity investments include professional venture capitalists (sometimes referred to as traditional or institutional investors and venture funds), business angels (also referred to as the nontraditional or informal investment community), and investment bankers. Common vehicles utilized by this community for raising funds and/or cashing out include Private Placements and Initial Public Offerings (IPOs). The Securities Exchange Commission (SEC) as a means of 
More detailed information on equity financing can be found in Chapter 7. protecting unqualified investors from unscrupulous entrepreneurs regulates both of these activities. As an aside, the SEC considers qualified or accredited investors to include:

D Company officers and directors

- Individuals with an annual income of over $\$ 200,000$ annually

D Individuals whose net worth is over $\$ 1$ million

- Broker/dealers

- A wide range of financial institutions are also considered accredited or qualified investors (See The Entrepreneur's Guide to Going Public by James Arkebauer for more details)

A modified version of the model we have been developing is depicted below. It shows the primary sources of equity investments and the wide range of intermediaries that often serve as a buffer between entrepreneurs and equity investors. This community, more than any other, relies heavily on the use of intermediaries. Although one can also go directly to equity investors, the recommendation of a trusted intermediary is often beneficial.

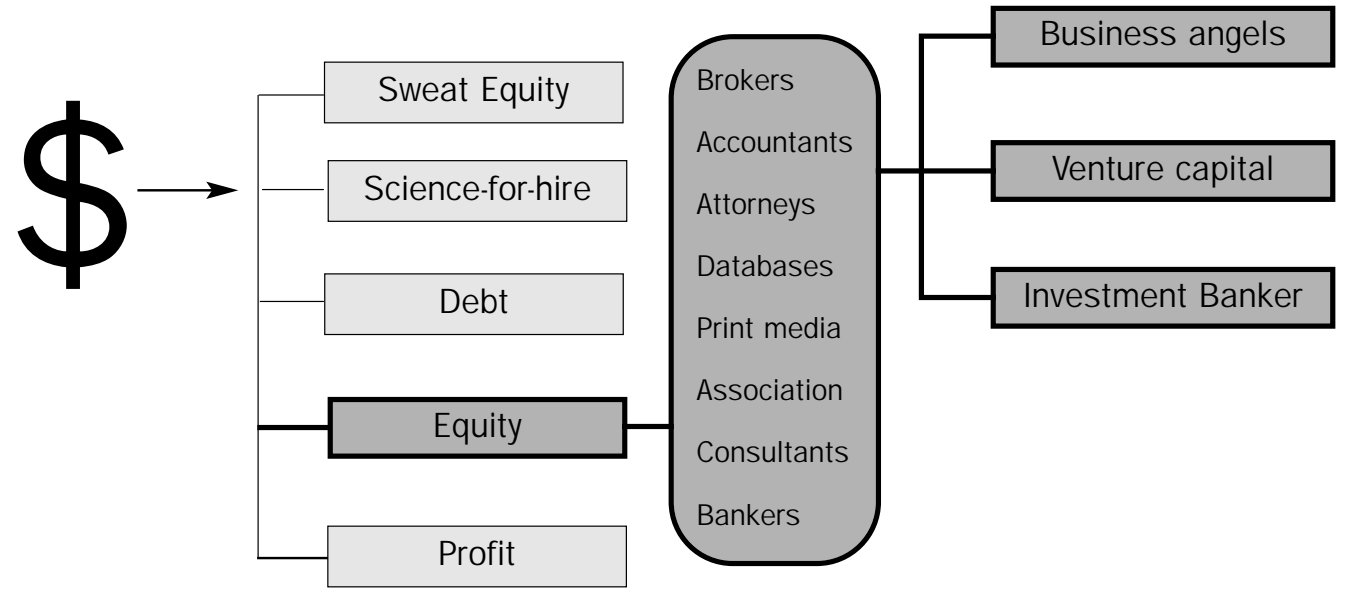

\section{Availability of Equity Financing}

The availability of equity financing from business angels, venture capitalists, and investment bankers varies widely. Although one hears frequently about the venture capital (VC) community, the business angel market is considerably larger. 


\section{Business Angels}

Business angels are typically self-made individuals with large net worth. This group includes medical professionals, lawyers, accountants, successful entrepreneurs and middle managers looking to move out of large corporations. The transactions of angels are unregulated, so it is hard to determine the actual size of this risk-capital pool. Some have estimated this to be a $\$ 50$ billion-per-year capital pool, and others estimate it to be considerably higher. There is wide agreement, however, that this pool provides the largest source of financing for start-ups in the country. It is estimated that angels have backed between 50,000 and 100,000 companies and that $29 \%$ of angel funding has been provided at the seed stage (Wetzel, 1989;

Hughes, 1989).

\section{Institutional Venture Capital}

By comparison, the size of the venture capital market is smaller and varies tremendously from year to year. For example, the total amount of venture capital committed in 1980 was $\$ 661$ million. In 1996 it reached a high of $\$ 11.6$ billion. According to the Wall Street Journal (August 1998), 1998 could be the best year ever. The highest investments have been in communications, computers, software, and biotech.

Clear geographic patterns exist in venture capital investments. In 1997, a total of $\$ 8.5$ billion was invested in the internet, and a sizable part of that was invested in Silicon Valley. In the second quarter 1998, one-third of all venture capital investments was made in Silicon Valley ( $\$ 1.25$ billion, in 224 companies). New England came in second with $\$ 379.5$ million invested in 86 companies, and the Southeast region received $\$ 348.2$ million, invested in 73 companies.

Historically, the venture capital (VC) market has been far more conservative than the business angel community. A significant difference between angels and institutional venture capitalists is that business angels invest their own money, whereas VCs invest other people's money-primarily from pension funds. With this level of fiduciary responsibility, VCs have historically been more conservative in their investments than angels have been.

Figure 2-6 provides an overview of the industries in which the venture capital community invested during the first quarter of 1998. During that quarter, the total value of investments made was approximately $\$ 3$ billion.

One-third of venture capital funding went to Silicon Valley and nearly $48 \%$ to software and information services.

-Source: Boston Globe, August 16, 1998 
FIGURE 2 - 6: VENTURE CAPITAL INVESTMENTS BY INDUSTRY ( 1 ST QUARTER， 1998 )

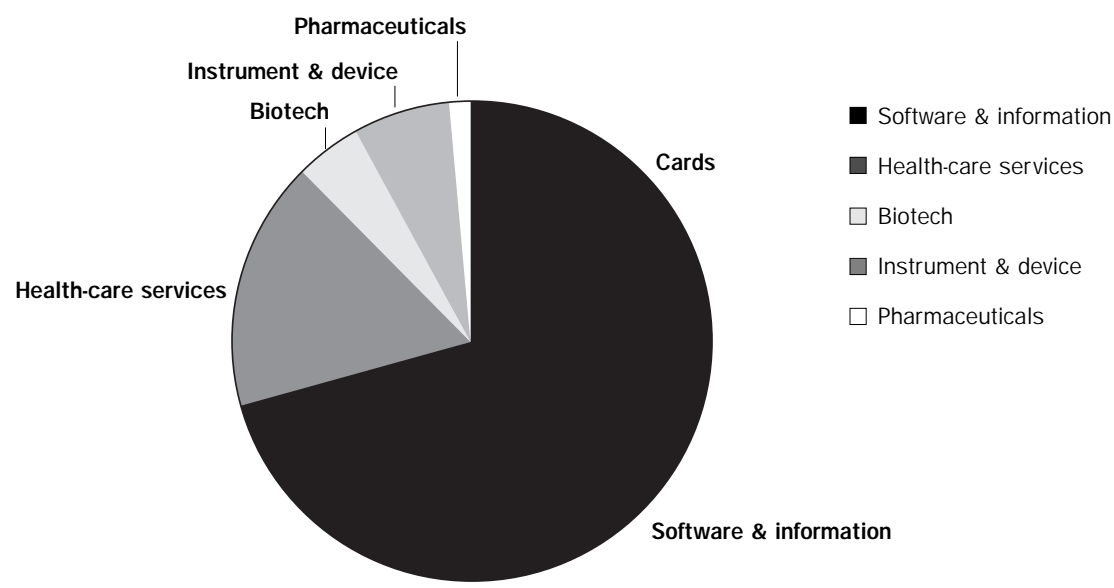

\section{Initial Public Offerings}

As mentioned earlier, Initial Public Offerings (IPOs) are regulated by the Securities \& Exchange Commission (SEC) and involve the sale of stock to both qualified and unqualified investors. The size of this market is also quite volatile, ranging from $\$ 6$ billion in 1969 to almost \$40 billion in 1993.

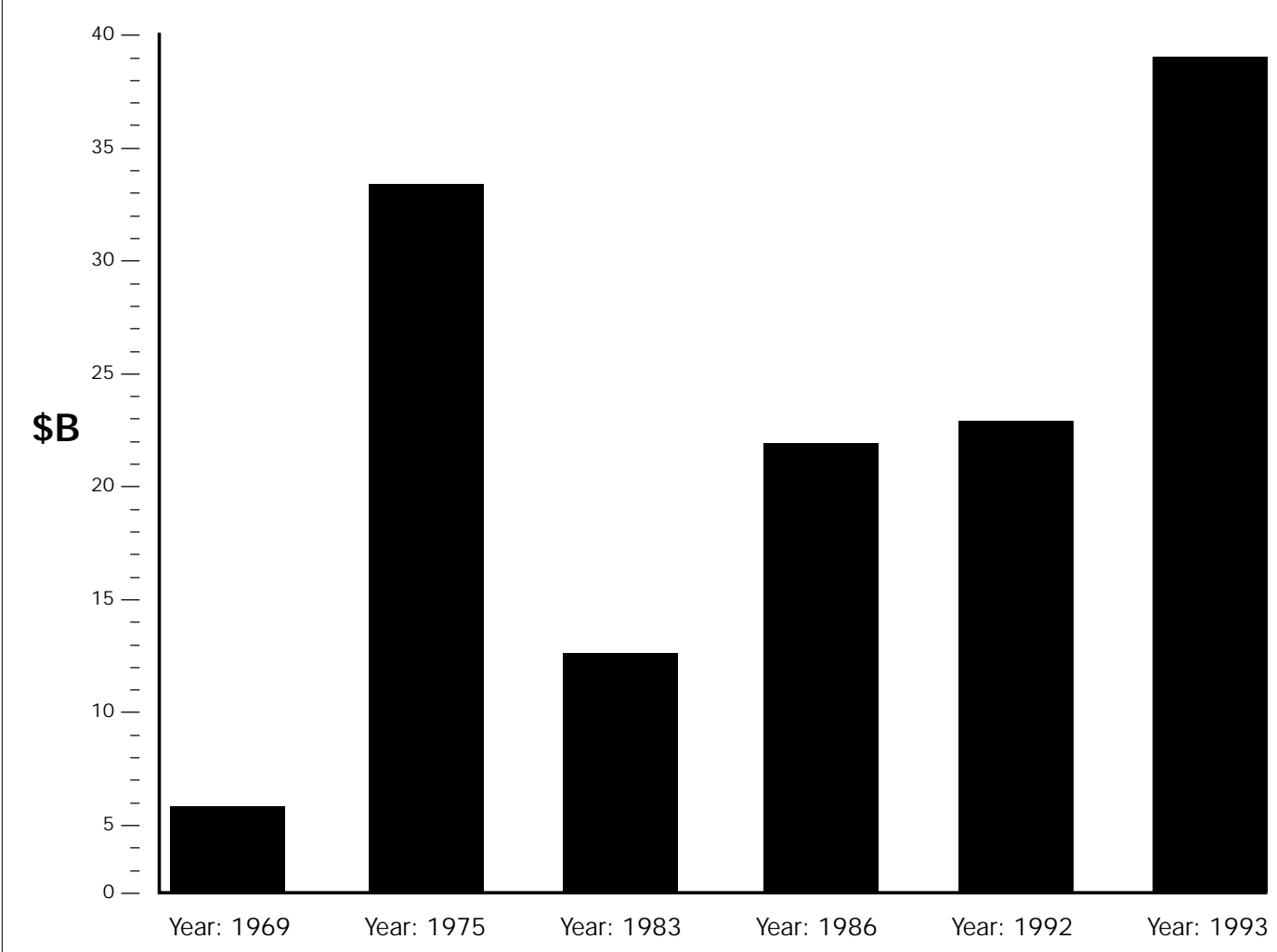


A small entrepreneurial company looking to get on the fast track is most likely to raise money from angels, then from institutional venture capital investors, and lastly IPOs. There are many other factors to consider besides the relative availability of funds, however, when deciding whether you should seek equity investment, and if so, from what source. Before going to the equity market, familiarize yourself with the terminology used to describe the stages at which investments are made.

\section{Stages of Equity Financing}

Equity investors use various terms to describe the stages at which equity financing is provided. These terms reflect the degree of risk and changes in the types of activities typically accomplished by the firm receiving the investment. Moving down the list from top to bottom, one moves from the most to the least risky.

Each of these terms is described below. There is some variation in how investors use these terms, however, so you should seek clarification of terms when you encounter them, to confirm that they are being used in the same way:

EARLY-STAGE FINANCING means financing that is available during periods when no revenues are being generated (see also Seed Financing and Start-Up Financing).

SEED FINANGING refers to early-stage financing of under $\$ 1$ million. Such monies are usually spent on product development, market research, business plan development, and the hiring of the management team.

START-UP FINANCING refers to early-stage financing typically provided to those who are "ready to do business."

FIRST-STAGE FINANCING is funding needed to initiate full-scale manufacturing and sales.

SECOND-STAGE FINANCING is capital provided at times of expansion to provide operating capital for a company that is shipping product, although the company may not yet be profitable.

MEZZANINE FINANCING is for companies that are beginning to turn a profit and require funding for expansion of various functional elements of their business.

BRIDGE FINANCING is funding provided to companies that plan to go public within six months to a year. 
Management!

Management!

Management!

Venture capitalists don't deal

with sole proprietors.
LEVERAGED BUYOUT means using the assets of the acquired company to help fund its acquisition by an outside party.

\section{What Do Equity Investors Look For?}

Equity investors look at the management team of a company in which they are considering making an investment. Unlike banks and other sources of debt financing that require collateral to assure repayment of their loans, equity investors view the management team as paramount to the success of the business and realizing a return on their investment. A seasoned, well-balanced team serves as a form of human collateral, as it is the management team that makes the opportunity come alive. It is often said of venture capitalists that they prefer a Grade A management team with a Grade B plan to a Grade A plan with a Grade B team. This statement is not intended to minimize the importance of a good business plan, but rather to indicate that a strong management team is needed when seeking venture capital. According to John Preston, previously with MIT's Technology Transfer Office, a strong management team is one that "keeps a healthy balance sheet, has a clearly focused strategy, and is realistic about marketing."

In other words, before approaching an equity investor, the technology entrepreneur should realize that venture capitalists don't deal with sole proprietors. A well-balanced management team includes individuals with expertise in at least three areas: (1) finance and administration, (2) sales \& marketing, (3) and R\&D, engineering and manufacturing (as appropriate).

If a venture capitalist invests large sums of money in a company, it is likely that he or she will require a seat on the Board of Directors and will take strong interest in-and work hard toward-the company's success.

The venture capitalist becomes an important part of the team. When courting an equity investor, one should ask for references, as well as the names of other entrepreneurs in their portfolio who can be contacted. It is also helpful to ask about their contacts in your industry and their experience with your company's technology. Look for the synergy and the value these investors can add.

Keep in mind that while venture capital firms sometimes invest on their own, they often invest in conjunction with others as well. (They may invest as part of a syndicate - a cluster of investment firms-for example.) In addition, a number of Fortune 500 companies have venture capital arms affiliated with them or other venture capital firms with which they often team. If your technology or product will eventually be a good acquisition candidate for a large firm, determine if that firm has a venture capital arm or a venture capital company with which it teams.

A F I NANCING PR I MER

(c) DAWNBREAKER PRESS, 1998 


\section{What Do Equity Investors Want in Return?}

Equity investors make money by helping firms grow. They then cash out, usually at year five. The phrase "cashing out" implies the following:

- going public via an Initial Public Offering, or

D selling stock, either back to the company or to another company, at a premium

These two techniques for liquefying the initial investment are referred to as Exit Scenarios. The whole intent of equity investors is to invest money in exchange for equity (ownership of stock); to sell the stock (liquefy their investment) in about five years; and to realize a substantial return on their investment (ROI). A substantial return is approximately 5 - 10 times their initial investment. That would mean that on an investment of $\$ 3$ million, equity investors would look to make $\$ 15$ - $\$ 30$ million in 5 - 10 years. This is typically done by substantially increasing the value of the company and then conducting an IPO or selling the company.

\section{Return on Investment (ROI)}

The earlier an equity investor invests in a company, the greater the return on investment (ROI) the investor expects-and the greater the equity in the firm that the firm must give up. According to Garner et al., "It is not uncommon that firstand second-round capital might take 40 to 60 percent of the equity shares, and succeeding rounds of financing, including public offerings, may leave the original owners with as little as 5 to 20 percent of the stock" (1994, p. 70).

Most venture capital firms are not interested in running the day-to-day operations of a firm as long as the company is doing a good job of creating value. However, if the company's management doesn't keep stride with the demands of a fast-growing venture, it runs the risk of being replaced. Technology entrepreneurs can minimize the likelihood that this will occur if (a), they seek a role in the rapidly growing company which allows them to utilize their strengths or (b), they form a spin-off company to which they license technology developed in a closely-held firm and seek a good management team and equity investments in the spin-off.

Business angels, venture capitalists, and investment bankers look for similar things in making equity investments. However, business angels, being an informal, part-time investment source, tend to be more lenient and patient with their money. Chapter 7 provides more detailed information on equity investors.

In summary, the risk-capital community is made up of three distinct types of equity investors: business angels, venture capital, and investment bankers (who issue IPOs). The business angel community is the largest, and is responsible for

VCs tend to be more risk adverse and wait to enter a deal when technology and market risks have been decreased. 
much seed financing. Such investors invest their own funds. They each make a couple of deals a year. The venture capital community is considerably smaller, and makes fewer investments in early-stage companies. VCs invest other people's money, primarily from pension funds. They tend to be more risk averse, and wait to enter a deal when technology and market risks have been somewhat decreased. The IPO market has been booming and is appropriate for high-potential ventures to consider. An IPO is an expensive process and one that totally changes the future operating procedures of the company. In all cases, equity investors take equity or ownership of company stock and look to make a significant return on their investment.

\section{Conclusion}

The purpose of this chapter was to provide a general overview of the financing options that a high-tech firm could consider for advancing the commercialization of its technology. These options include sweat equity, R\&D partnerships, debt, equity, and profit. ATP awardees have already made some financing choices prior to submitting their ATP proposal. Advancing the commercialization of that technology requires ongoing attention to additional forms of financing. 


\section{Commercialization Strategies}

WHAT IS A

COMMERCIALIZATION STRATEGY?

PROTOTYPICAL

COMMERCIALIZATION STRATEGIES

StRategy 1 :

LICENSING WITH DEVELOPMENTAL

FUNDS

StRATEGy 2 :

STRATEGIC ALLIANCES

StRATEgy 3 :

EQUITY INVESTORS IN THE PARENT COMPANY

StRategy 4 :

EQUITY INVESTMENT IN A SPIN-OFF

STRATEGY 5 :

INITIAL PUBLIC OFFERING

CONCLUSION 


\section{What is a Commercialization Strategy?}

The phrase commercialization strategy refers to the series of financing options that a company entertains to move its technology/product from concept to the marketplace. As was discussed in the previous chapter, an increasing number of financing options become available to a firm as a product approaches completion, as collateral is developed, and as market risk is decreased.

The financing options available to your firm also depend upon your vision for the future. Do you envision your company remaining a contract research and development firm? Will you commercialize by licensing your technology to others, or do you wish to perform most business functions within your own firm? Are you willing to share control of your enterprise with equity investors, or is your goal to develop a closely held firm? These are important considerations that will affect the preliminary shape of your commercialization strategy. Your vision acts as an anchor point.

A commercialization strategy will also be affected by personal philosophies about business. It is not uncommon for founders to start a firm with the following premise: "I want to grow this company without giving up any equity." Others may decide, "I don't care who else gets rich off my business, as long as I retain the right to do what I enjoy and make good money in the process." Still others may assume, "I am going to pay for the best help available. I don't believe in getting something for nothing." Such philosophies may not be expressed in so many words, but be aware that such underlying philosophies may influence your choices for a commercialization strategy.

If you are developing a technology platform with the ability to affect multiple industries, you will also need to include an assessment of which applications you believe will develop first. This should be discussed in their commercialization strategy, and potential markets should be rank ordered in terms of their readiness. A company should position itself to hit windows of opportunity on time.

Vision, business philosophies, and a logical assessment of market opportunities are all-important considerations when developing a commercialization strategy. However, when positioning a firm to be a high-potential venture, the ultimate strategic choices made will be decisions that keep you ahead of the competition and enable you to hit the window of opportunity. You must estimate when your product will be commercially available, when your principal competitors are likely to enter the market, and when your target customers will become responsive to your technology/product. Work backward from this target date, setting your firm's

By the time a company submits an ATP proposal, it has already selected one or more commercialization strategies to pursue. However, the complexity of the task at hand requires constant re-evaluation of one's strategy.

A commercialization strategy is affected by:

D your vision,

D your business philosophy,

- the stage of technology development,

- market risk,

- competitive activities,

D window of opportunity. 
Licensing-in is the term used to describe the process of obtaining rights to use the intellectual property of others, external to a company.

By contrast, the inventor or small company which is granting the license, licenses-out. marketing, research, and financing milestones on the timeline necessary for you to hit the projected date of market entry. Seizing your market advantage will increase the likelihood of realizing the objective of becoming a fast-growth firm-one that will create value for you, your commercial partners, and your investors.

\section{Prototypical Commercialization Strategies}

This chapter introduces you to a variety of commercialization strategies that advanced technology firms have used successfully:

\section{Licensing with developmental funds}

Strategic alliances

Equity investment in the parent company

Equity investment in a spin-off

Initial Public Offerings

Each of these strategies usually involves several stages of financing. Although the last step used is the one that lends each strategy its name, the other modes of financing are included, too, in the tables that follow. These tables also list the type of "vision" for each of the hypothetical enterprises described, as well as a statement of each one's "philosophy."

\section{Strategy \#1: Licensing with Developmental Funds}

Many life-style firms use licensing as the commercialization strategy of choice. With this strategy, the advanced technology firm specializes in technology development and limits its marketing and sales activities to the overtures it makes to potential licensees. The licensees, in turn, perform all of the other tasks associated with commercialization-marketing, sales and distribution, engineering, manufacturing, and the like. In this day of shrinking research and development budgets in large corporations, licensing-in is increasingly a strategy of choice if the technology enables the licensee to enter new markets or retain market position without having to make costly investments in the original R\&D, skilled personnel, and/or equipment.

Table 3-1 provides a thumbnail sketch of the commercialization strategy used by a small, advanced technology firm (not an ATP awardee) using a licensing strategy. This table is followed by an excerpt from an interview with a company president describing why his firm used this strategy and how the firm made it work. 
Vision: Life-style company

Philosophy: "I want to enjoy what I do best."

Financing methods:

- For preliminary $R \& D$, participated in a Federal contract for $R \& D ;$ paid careful attention to intellectual property.

- Periodically used revolving line of credit for working capital (debt financing).

- Approached another company to complete commercialization of technology.

- Procured a private contract for application-specific $R \& D$. Retained some rights within other markets.

Under the Federal Acquisition Regulations (FAR), a small business such as ours retains the rights to the technology it develops for the government outside the government arena. As a result, we have quite a few undeveloped, patented technologies "on the shelf." We generate 4-5 patented technologies each year.

Large corporations become familiar with both our expertise and our technologies through our technical literature and conference presentations. Later, they approach us to solve a problem in one of our demonstrated areas of expertise. This usually involves developing one of our undeveloped technologies to solve a specific problem of interest to them. Many of the technologies, though patented by us, are still at quite an early stage of development. A great deal of inventing must still take place during the development process to adapt our technology to our client's specific application needs.

\section{Summary}

The party interviewed clearly leveraged the R\&D developed under a Federal R\&D contract. The company paid careful attention to intellectual property; was mindful of the importance of developing and maintaining relationships with champions; and entered contractual arrangements with corporations on a realistic basis. 


\section{Strategy \#2: Strategic Alliances}

Soul-searching often leads company founders to decide that they don't wish to assume certain business functions. This often happens, for example, when the company makes a component for, or an enhancement to, a system. After weighing the pros and cons of manufacturing and marketing the component to a limited number of system integrators, it may seem more appropriate to form a strategic alliance with an entity in the supplier chain. The immediate customer could become a site for testing the technology/product, a potential licensee, or an investor in the firm. When a company makes a decision to mutually align itself with a customer, it has developed a strategic ally or teaming partner. Many types of strategic alliances can be formed for purposes of marketing, R\&D, manufacture, equity, joint ventures, and/or licensing.

\section{TABLE $3-2:$ STRATEGIC ALLIANCES}

Vision: Foundation company (R\&D and manufacturing)

Philosophy: "Conservative"

Financing methods:

- For preliminary $R \& D$, participated in a Federal $R \& D$ program (not ATP); paid careful attention to intellectual property.

- Obtained equity investment from foreign investor, later converted to debt.

- Formed strategic alliance with customer (To supply our component for his system).

Zentech received its first Federal funding in 1986. Its decision to respond to RFPs has traditionally been driven by the company's marketing and financial strategies. Routinely, Zentech examines the market looking for "market-pull" opportunities for its technologies and products. If it sees opportunities to commercialize a particular application, the company then examines RFPs from the various Federal agencies to determine if there is a good strategic fit. Zentech will not bid on RFPs for which it has not independently assessed a market need that fits with the company's mission.

Zentech manufactures a widget that is sold to manufacturers of a high-tech system. In 1986, Zentech employed 42 people. Today, it employs 135. Its growth has been primarily 
dependent upon a philosophy that can only be characterized as "getting close to the customer." This trial-and-error approach has been of great value.

Zentech initially spent a lot of time knocking on doors, presenting its idea of what the customer wanted, and then receiving corrections from the customer. Through the process of "getting close to the customer" it has developed a strategic alliance. When initially assessing the market, Zentech realized that the opportunity for a return on its investment would only come if the widget were successfully integrated into its customer's high-tech system. Therefore, in mapping out the $R$ \& $D$ and marketing strategies, it anticipated the final goal not as production of the widget, but as utiliwation of the widget as a critical component of the customer's high-tech system. That last phase of the plan has been financed by the customer. The customer's motivation in this process was sparked by the fact that the use of the widget in a new high-tech system would open up new markets.

Funding has always been a challenge to Zentech. The company initially received equity financing from an overseas firm. The foreign investor provided the cash and Zentech provided the technology. This initial funding enabled the company to conduct its preliminary work with customers. However, funding problems on the part of the investor, coupled with its early success, led Zentech to buy back its equity.

For Zentech, the hardest part of the commercialization process has been obtaining good data on performance in actual field locations. The company had to expend a lot of effort to gain permission from potential customers to install the equipment, obtain good field data, and convince them to continue running the tests.

At one point, when reviewing its strategies for growth, Zentech considered getting into the manufacturing of the high-tech instrument. However, when it assessed this market it learned that 20-24\% of the gross sales of the instrument market was spent on sales promotion and service. Upon reflection, Zentech decided that it did not wish to develop a large sales force or customer service department or pay for the costs involved with developing the high tech item itself. It made a strategic decision to continue manufacturing the widget and not get into the high tech instrument business. It only spends 5\% of gross dollars on sales and services, has a smaller staff, and needs only one location.

Zentech presently has 14 ongoing programs, including one (non-ATP) federally funded program. It must ramp staff up and down quickly and plan shifts for its staff between programs, sometimes anticipated over a year in advance. Staff members are shifted to support funded programs. Zentech has commercialized one model of widget, obtained a "design win" on another, and applied for three patents. Its management feels that the strategies being followed are allowing company growth while staying within the constraints of prudent financial management." 


\section{Summary}

Strategic relationships are on the increase, intertwining the future of companies in a sequence of customer-supplier relationships (Hanan, 1992). A good alliance is like a good marriage, and requires that respect and fair play characterize the relationships. Ohmae (1989) recommends that participants do the following in order to develop successful collaborations:

- make a personal commitment to the alliance;

D have mutual respect and trust;

D take time to develop and maintain the relationship;

D clarify the relationship in a contractual form and then quickly put the contract away;

D clarify mutual expectations and timeframes;

D maintain an awareness of the partner's problems;

- learn to interpret particular responses in a culturally appropriate way;

D recognize a partner's independence; and

- celebrate success together

Some ideas about how to maintain good relationships are expressed in the interview excerpt below:

We put a lot of effort into establishing and maintaining relationships, keeping each other informed of travel plans to conferences-so that opportunities to interact remain constant. You have to work the relationships up and down the ladder. Management needs to dialog with management, and technical people in both firms need to interact with one another.

Networking is important. Our people attend approximately 20 conferences a year. It is a major investment of time and resources, but enables us to develop and maintain relationships, and to keep interested parties aware of our new research efforts through the conference presentations that we make.

\section{Strategy \#3: Equity Investment in the Parent Company}

Often times the founder knows at the outset what type of firm he/she wishes to develop. If the founder has the vision to become a high-potential venture, he/she will begin to make decisions from day one that will position the company for rapid growth. An example of such planning follows: 


\section{Vision: High-potential venture}

Philosophy: "Rich is good!" "Selling is like shaving.

If you don't do it every day, you're a bum!"

Financing methods:

- Sweat equity

-Federal SBIR funding

-A private placement

- Debt financing from an equity investor

FastTrack had its eyes on becoming a fast-growth company from the get-go. The founder had both a business and a technical background, and was very familiar with federally-funded $R$ RD partnership programs. After investing sweat equity to get the company started, the founder applied for SBIR funding. After winning both a Phase I and Phase II award, he quickly assembled a multi-disciplinary team. Vested in the vision of becoming a high-potential venture, the team worked diligently on issues related to business planing, leveraging their time to complete this task by utilizing assistance from a local university.

To accelerate the rate of market entry and to allow the company to gear up for manufacturing, the founder decided to conduct a private placement. Equity investors were courted for a couple of years, but only became involved once market risk had decreased and sales were doing well. The team negotiated a loan from an institutional investment firm.

\section{Summary}

The vision a founder has for the future of a company directs and focuses the firm's activities. In the example provided above, FastTrack, knowing that it wanted to position itself to be a high-potential venture, relied on a wide variety of financing options.

\section{Strategy \#4: Equity Investment in a Spin-Off}

A complex strategy, but one which can be exercised successfully, equity investment in a spin-off is a hybrid of the approaches already discussed. The founder of the technology firm decides that he or she wishes to keep the company fairly small, 
Human resources, intellectual property, and non-compete arrangements need to be artfully addressed. focused on research and development, and privately held. However, the founder entertains spinning off a related company in which equity investments could be made, the intent being to grow the spin-off as a high-potential venture. In order to make this strategy succeed, issues related to human resources, intellectual property, and non-compete arrangements need to be artfully addressed.

With respect to human resources, any entity seeking equity investment must have an excellent management team in place. The dilemma should be apparent. The founder of the parent company should not be in both the parent firm and the spin-off, because of split loyalties. Because an equity investor wants to be assured that the management team is fully committed to making the venture a success, such an arrangement is generally unacceptable. The technology entrepreneur, therefore, tends to stay with the parent firm. This requires that another management team be assembled to drive the growth of the spin-off. Most companies contemplating this strategy do not have the resources available to hire a management team for another firm prior to receiving an equity investment. They therefore have to grapple with how to address this requirement.

One strategy is to have a phantom management team in the wings that could step in once equity financing is obtained. This is not an optimal alternative for an equity investor, but one that is understandable.

A second strategy is to groom a vice president from the parent company to become the president of the spin-off. This has benefits to the spin-off, but creates a hole in the management team of the parent company. Some technology firms, strapped for resources, utilize a third strategy and offer the position of president to a retiring executive, often from a large firm. This is done because the executive may have a golden parachute that he is willing to invest in the spin-off, or because it is believed that his contacts should attract capital. This strategy is risky, however, as executives from a corporate environment usually do not have experience growing a high-potential venture. There is a big difference between building a car (i.e., working in an entrepreneurial environment) and driving a car (i.e., working for a large corporation).

You will be best served by involving a management team that has had experience in growing a company-a team that has contacts in the market of interest and has a pedigree that will satisfy the needs of equity investors. The bottom line: If you want to form a spin-off, you must grapple with how to best proceed to put a capable, dedicated team in place to drive the growth of the venture.

The intellectual property issues must also be adequately addressed. Formal arrangements that license or sell the intellectual property to the spin-off must be drafted. The terms need to be appropriate to allow an incentive for the management team and the equity investors, while still providing a return to the parent company. If there are restrictions on market applications to which the technology may be applied, these must be discussed and clarified. 
A related issue is non-compete arrangements. You must decide if any R\&D will be conducted in the spin-off or if it will take place only in the parent company. You must clarify whether the spin-off will have the right to obtain intellectual property from other sources in order to expand its intellectual property estate, or whether all intellectual property will have to come from the parent company.

\section{Summary}

A spin-off strategy can work well. However, issues related to human resources, intellectual property, and non-compete issues need to be addressed. An equity investor will have no interest in the spin-off if it is unduly fettered or if it is a sham.

\section{Strategy \#5: The Initial Public Offering}

Perhaps the most glamorous commercialization strategy is an Initial Public Offering (IPO). Going public is the ultimate sign that you have arrived. It is a means of recapitalizing your firm, appreciating the value of stock, and the most common means for allowing equity investors to cash out. It brings lots of attention to your company and is a good strategy to use if you are positioning to be acquired or merge with another firm. It is also by far the most expensive commercialization strategy, requiring large amounts of money to be paid to underwriters, attorneys, accountants, public relations firms, printers, and state and Federal organizations. A company that goes this route will never be the same. In exchange for the glamour and the rapid capitalization of the company, one acquires a public of owners who have the right to full disclosure from that time forward.

Vision: High-potential venture

Philosophy: I want to do it, I want to do all of it!

Financing methods used:

- Sweat equity and owner's equity

$-A$ Federal $R \& D$ partnership

- Seed financing from venture capitalists and angels

- Equity investment from a Fortune 500 company

- Second round financing from venture capitalists

-A private placement

-A line of credit from bank

- Profits plowed back into the company

-Initial Public Offering 
As can be seen from the list of financing methods, a company positioning itself for this future will spend considerable time working on financial planning. The technology entrepreneur has to be mindful from the start that every time equity is given away, the return for subsequent investors and the founders must be anticipated. As cited at the beginning of this chapter, "You read a book from the beginning to the end. You run a business in the opposite way. You start with the end, and then do everything you must to reach it."

Reaching the goals set requires planning — business planning made in light of your vision for the company's future. The examples provided in this chapter have been fairly straightforward. However, often the richness of a technology platform dictates a far more complex approach to issues of commercialization. In such instances, the technology entrepreneur must step back, look at the potential impact the technology could have on multiple industries, and develop a constellation of strategies to realize the opportunity. The purpose of the next chapter is to provide guidance on how to develop a constellation of commercialization strategies.

\section{Conclusion}

A commercialization strategy refers to the series of financing options that a founder or management team chooses to pursue in order to bring a technology from concept to the marketplace. Attention to a commercialization strategy must be ongoing because the strategy selected is dynamic and should evolve over time. Commercialization strategies are affected by many factors, including (1) the vision and business philosophy of the founder, (2) the stage of technology development, and (3) industry and market conditions. The degree of technology risk, market risk, a competitor's activities, and the window of opportunity should all affect a company's commercialization strategy. 


\title{
Complex Strategies for Rich Technology Platforms
}

\author{
AdVAnCED ORGanizer \\ SUSTAINABLE COMPETITIVE \\ A DVANTAGE \\ ECONOMIC BARRIERS IN \\ TECHNOLOGY PARTITIONING \\ STRATEGIC PLAN \\ CONCLUSION
}




\section{Advanced Organizer}

In Chapter 3, the concept of the commercialization strategy was introduced and suggestions made regarding how to develop a sound strategy for bringing a product to market. When a company has a rich technology platform, an additional dilemma arises. Specifically, when many product options are possible:

D Where should the small firm focus its limited resources?

Dhat type of commercialization strategy(ies) should it pursue?

Dith whom should it partner?

D How should it decide what constitutes a good deal?

D How can the firm grow rapidly and still remain intact?

The answer to these questions lies in maintaining the company's sustainable competitive advantage. By the end of this chapter, the reader should be prepared to develop a strategic plan that addresses the commercialization of a rich technology platform.

\section{Sustainable Competitive Advantage}

To grow and flourish, a company must have a sustainable competitive advantagethat is, an advantage that will give the company staying power over the long haul. The types of things which provide a company with such an advantage include:

D Intellectual property: patents, trade secrets, copyrights, trademarks

- The uniqueness of the technology and the limited number of people who have expertise in this area (hopefully, many of them are employed by the company)

- Cost of entry

- Strategic allies and champions

- Marketing and sales capabilities, access to distribution networks, and the quality of the work done

- The company's record with respect to selecting successful new products or technologies, as well as its ability to keep to development timelines
In developing an ATP proposal, submitters are asked to identify multiple applications. The challenge in the post-award period is to make those possibilities a reality. 
This chapter focuses on how to assess the possible applications of a rich technology platform and on how to combine this assessment with decisions and actions which will assure that your company is appropriately developing those aspects of sustainable competitive advantage associated with its particular technology.

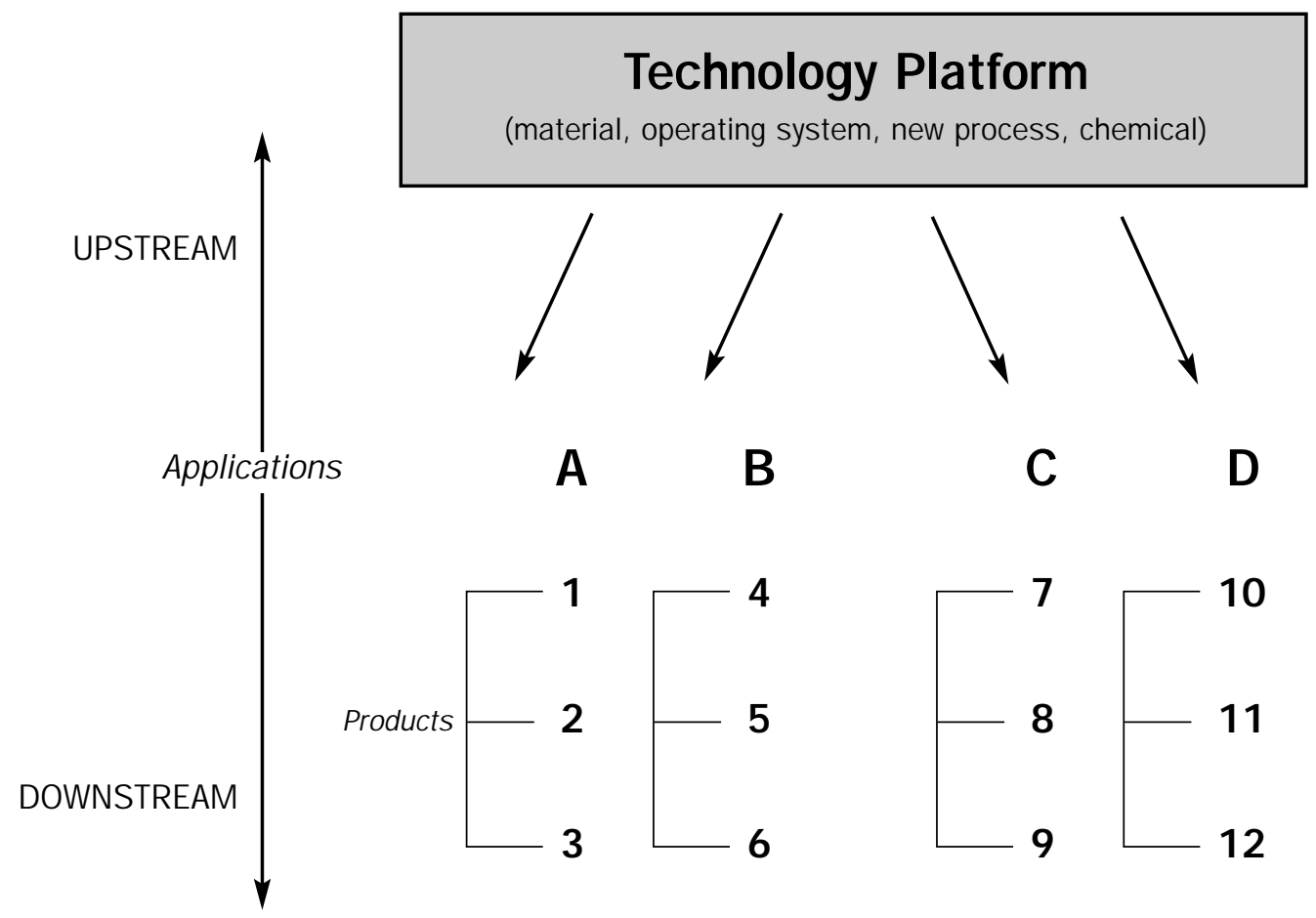

Figure 4-1 depicts the possibilities presented by a rich technology platform, such as a new composite material. The properties of the material make it ideal for use in a wide variety of applications as diverse as leisure (golf clubs) and spacecraft (shielding). The dilemma for the small firm is how to effectively exploit all these possibilities. The answer is that a small company can't-on its own. Limitations of time, money, and resources make it infeasible for most companies, large or small, to fully exploit all the possibilities presented by a revolutionary technology. In such situations, a company must consider implementing a constellation of strategies, and decide which application it will pursue on its own and which it will pursue in combination with others. Figure 4-2 is a shorthand way of representing which strategies to consider. Such considerations are made as a function of the number of possible applications to be pursued and the amount of financial resources required to exploit them. 


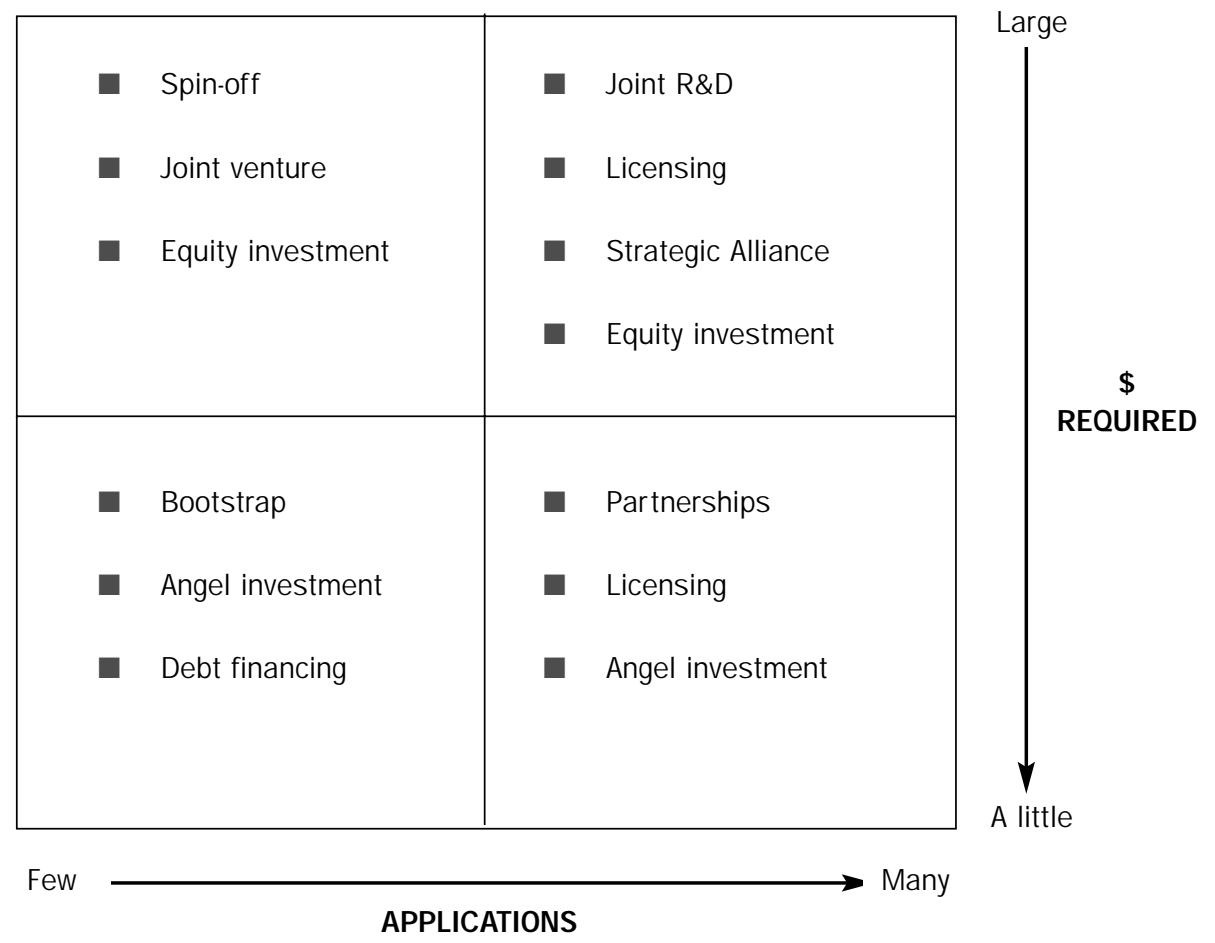

Figure 4-2 represents financing options to consider as a function of the number of applications for the technology, as well as the perceived financial resources required. For example, if a technology has few applications and requires limited resources for successful commercialization, the firm should be able to realize this opportunity on its own, by bootstrapping. However, even with limited applications, if significant funding is required, one should consider seeking direct investment in the company, a joint venture, or a spin-off. If the technology has many possible applications, then one should consider a wider range of strategies, involving a larger universe of potential partners.

Most new technology entrepreneurs don't have a good basis for knowing how much money its takes to bring a product to market, so it is important that this figure be examined. For example, "The R\&D costs to generate and maintain the technology required for each new chemical entity is now greater than $\$ 100$ million and increasing. ... To maintain the $10 \%$ pace of investment, each new chemical entity would have to generate, on the average, $\$ 1$ billion in sales over its lifetime, assuming no inflation." This is obviously not a task a small company can tackle on its own.

The implications are very clear. A company should assess whether it or other entities can best exploit various options. For example, if it truly won't take a 
lot of money to complete production and bring the product to market, the small company may be the best candidate to do it. However, as the amount of money required and the number of possible applications increase, the universe of commercialization strategies to consider also expands.

When trying to determine the constellation of strategies to pursue, you should simultaneously consider three issues:

(1) How can the basic and application R\&D be expeditiously completed?

(2) Which firms/investors will make the best partners to fully exploit the technology?

(3) How can you assure that your company maintains an essential role in the commercialization of the technology it originated?

\section{Completing Research and Development}

To maintain a substantial lead, firms developing pioneer technologies must assess not only what research and development needs to be accomplished, but also which partners may be good to involve in "upstream" activities (Heuss and Jolly, 1990). The greatest flexibility comes from strategic alliances, including consortia and joint ventures that are structured to preserve organizational autonomy and individual incentives (Teece, 1991).

Before deciding which firms/investors to approach regarding the downstream applications of your specific opportunities, you should assess the structure of the industries and the extent to which the opportunities can be partitioned.

Partitioning of multifaceted opportunities is usually the result of intellectual property protection and economic barriers. In the example represented in Figure 4-3, the company has developed a portfolio of intellectual property that protects the process for creating the material as well as the devices used to produce the composite. These both fall within the category of upstream applications. The company has also developed downstream, application-specific intellectual property it can license separately. A company interested in application-specific licenses would have to purchase the composite material from the Licensee that holds the exclusive patent on the production of the composite-or, if economically feasible, should consider trying to obtain an application-specific license or sublicense for its own production needs. 


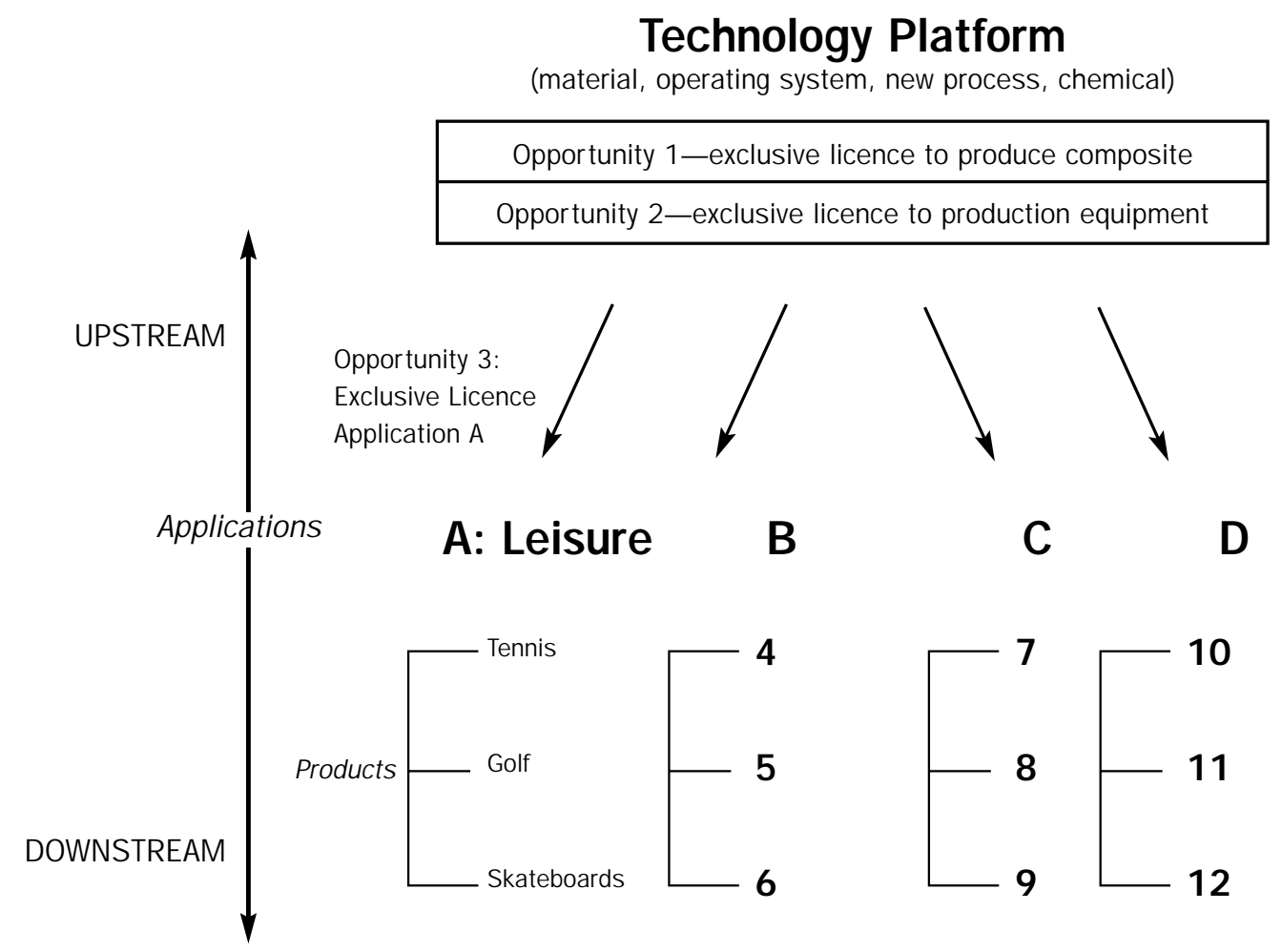

\section{Economic Barriers in Technology Partitioning}

The economic barriers that can be used in partitioning an opportunity are not actually created by the licensee, but rather are leveraged by him or her. With economic barriers, one is really taking advantage of the downstream infrastructure and the position of the dominant players within it. In other words, the goal is to prevent others from entering that market by making use of the existing infrastructure and relative positions of the key players.

When looking at the dynamics of various industries, one consideration should be to examine each industry relative to the presence of a dominant design (Teece, 1991). This is essential, according to Teece, since clever market entry strategies will keep innovation imitators at bay. Building on the work of Abernathy (Abernathy and Utterback, 1978), Teece maintains, "In the early stages of development of many industries and product families, designs are fluid, manufacturing processes are loosely and adaptively organized. ... Competition among firms manifests itself in competition among designs." This is evident in products and

Partitioning-dividing the domain of possible products and imposing or utilizing intellectual property or economic barriers.

Economic barriers:

D industry cohesiveness

D dominant players

- distribution channels

- dominant or emerging design

- certification \& regulatory requirements

- competitors 
protocols such as Apple vs. IBM computers, Netscape vs. AOL, VHS vs. beta, and the like. Prior to the emergence of a dominant design, a company can position its product to become an industry standard and/or should "hang loose" and resist becoming too tied to a design which may ultimately "lose." Teece recommends that if a company has the ability to promote a dominant design, it should do so.

However, if it lacks this capability, the firm should wait for the dominant design to emerge.

Once a dominant design has emerged, the emphasis shifts to more evolutionary innovations capable of driving down costs. At such times, it is often advantageous for a company (large or small) to team with other players with complementary assets and products. If a company has bet on the wrong horse, it is still possible to participate in the new design regime by forming strategic alliances through technology swaps, joint R\&D, co-development, or sharing of complementary assets. Teece clarifies what he means by complementary assets by drawing the distinction between what a customer perceives as a product and simply a device. An item that fully meets a customer's defined need will tend to be viewed as a product. For example, an optical scanner sold with a range of software, cabling, and customer support is likely to be viewed as a product-whereas a scanner sold without software is likely to be viewed as a device. A company which provides only part of a solution to a customer need should look to producers or providers of complimentary products, components, and services as potential strategic allies.

Other industry characteristics that are important to consider when deciding upon the commercialization strategies to be pursued include:

D Cohesiveness of the industry

- Premarket testing, certification, and regulatory requirements

D Product liability issues

D Channels of distribution

When an industry is fragmented, the formation of a strategic alliance is often an advantageous commercialization strategy to pursue. When significant capitalization is required for pre-market testing or to address product liability issues, significant investment will be required by a potential licensee, strategic ally, or equity investor.

An understanding of the dynamics within the various industries to which a rich technology platform can be applied is important before beginning the process of mapping out the commercialization strategies to be pursued. Finally, the company needs to consider how to structure relationships so that the originating company will maximize its participation in the financial benefits that result from commercialization of the technology. 


\section{Maximizing Financial Return}

Before determining how to maximize financial return from the commercialization of the technology platform, you must begin by generating a list of possible applications for the technology. Once this has been accomplished and you have examined the structure of each related industry, the company must decide where in this panorama it wishes to "hang its hat"-the place Heuss and Jolly refer to as the center of gravity. It is impossible to determine how best to maximize your return from other relationships before deciding where in this panorama you wish to play.

Determining your center of gravity is a function of your interests, your vision, and other considerations which allow you to maintain a degree of control over the evolution of the technology.

The progenitor's relationship to a newly created technology is unique. The inventor brings a heightened desire and commitment to see his or her technology utilized. Therefore, if you have a strong vision for your technology, you should carefully consider how far down the commercialization path you wish to proceed. As the progenitor, you are more likely to pursue a given path longer than others will. (According to Heuss and Jolly, licensees may drop a line of pursuit earlier than a progenitor.) Thus, if there are areas of technological risk which you feel would be difficult for others to navigate or to which they would be less committed, you should consider staying with the technology development course longer, before handing it off to another entity for the final stages of commercialization. The progenitor's commitment is a double-edged sword, however. Although persistence has its value, an inventor also needs to know when to let go. Nevertheless, in all cases, the more technology risk is decreased, the greater the return you can negotiate.

To remain attractive to potential partners, the technology entrepreneur should keep his or her technology in the spotlight, even going so far as to develop trademarks to help accrue goodwill. As Heuss and Jolly point out, developing trademarks "offer the potential to prolong market acceptance even after the underlying technology rights expired" (Heuss and Jolly, 1990).

\section{Strategic Plan}

An outline for a strategic planning document is included here. It is intended to be a proprietary, internal document used by ATP-funded companies that have a rich technology platform. Such companies often need to develop a constellation of commercialization strategies to fully exploit their given technology.

Remember, the value of a company's technology lies in the decisions made and actions taken to realize an opportunity! A strategic plan starts with analysis but must end in action in order to be of any real value. 
Commercialization Toolkit ${ }^{\text {TM }}$

- Strategic Plan

\section{STRATEGIC PLAN}

\subsection{Technology Platform}

1.1 List possible upstream roles by industry. These usually will be associated with production of raw material or equipment to be used across downstream applications.

1.2 List possible downstream application areas by industry and products nested within each industry. If possible, represent this in graphic form, similar to Figure 4-3.

\subsubsection{Industry 1}

Specific product or process 1

Specific product or process 2

Specific product or process $n$

\subsubsection{Industry 2}

Specific product or process 1

Specific product or process 2

Specific product or process $n$

\subsubsection{Industry 3}

Specific product or process 1

Specific product or process 2

Specific product or process $n$

\subsection{Intellectual Property}

In this section, map out your intellectual property strategy for partitioning the available opportunities, differentiating between base patents and application patents. Be sure to pay appropriate attention to other forms of intellectual property-copyrights, trademarks, trade secrets, and knowhow- and how these can be used to increase the dependence that potential partners will have on you.

\subsection{Patents}

Clarify which patents are pending and which ones have been awarded. Indicate which other innovations you are likely to patent during the process of commercializing the technology. 


\subsection{Trademarks}

Clarify which trademarks you have already registered, which ones you are using in interstate commerce and are not yet registered, and how you can use copyrights to your advantage vis a vis potential partners.

\subsection{Trade secrets}

Indicate whether you have or will institute appropriate procedures to assure that certain types of information are maintained as trade secrets. Indicate by broad category which types of information fall into the trade secret area.

\subsection{Know-how}

Clarify which types of information you have opted to maintain as "know-how" - and determine whether this information could potentially be of value to allies.

\subsection{Research and Development Timeline}

Draw upon your ATP proposal in completing this section. Provide an indication of key research and development milestones, as well as the approximate timeframe required to complete this work. Be sure that this section addresses the upstream and downstream applications indicated previously.

\subsection{Industry analysis}

This section requires considerable accomplishedindustry analysis. For each industry referenced in section 1 , indicate the following:

\subsection{Industry 1}

- cohesiveness of industry

- dominant players

- channels of distribution

\subsubsection{Relative to specific product}

- dominant or emerging design

Dremarket testing, certification, regulatory requirements

- product liability issues

- competitors 
Not a Straight-jacket! All of the suggested outlines in this document are intended as a guide, not a straightjacket. Please feel free to vary the format to suit your needs. The emphasis is on the content and NOT the form.
4.2. Industry 2
- cohesiveness of industry
- dominant players
- channels of distribution

\subsubsection{Relative to specific product}

- dominant or emerging design

- premarket testing, certification, regulatory requirements

- product liability issues

- competitors

4.3. Industry 3

- cohesiveness of industry

- dominant players

- channels of distribution

4.3.1. Relative to specific product

- dominant or emerging design

- premarket testing, certification, regulatory requirements

- product liability issues

- competitors

\subsection{Center of Gravity}

In light of the preceding, and in consideration of your personal vision, which business functions to you wish to reserve for yourself? What is the mission of your company?

\subsection{Mission}

In this section, clarify the business functions you will perform.

\subsection{Intellectual property}

In this section, list the intellectual property rights you wish to retain exclusively for your firm, i.e., those you will not share with a partner.

5.3. Industry/ market focus

In this section, clarify the industry, or more specifically the market, you need to tackle on your own. 


\subsection{Commercialization strategy}

In this section, clarify how you will fund the commercialization of what you have carved out as your center of gravity.

\subsection{Strategies and Partners for Commercializing Related Opportunities}

In this section you will map out how you will exploit other opportunities. The timing associated with the unfolding of this plan will be driven by the research and development timeline clarifiedoutlined in Section 3. Start by developing a list of upstream and downstream opportunities sequenced according to when the R\&D would be complete. Then, conduct another sort of the information, based on the difficulty associated with bringing the product to market. Consideration should be given to factors such as premarket testing, certification, and regulatory requirements. Finally, indicate whether there is a dominant or emerging design; also, the relative size of the market opportunity. In addition, note the amount of money required to commercialize the technology. The clearest way to do this is to represent this information in tabular form.

For example:

In light of the industry information presented earlier, your consideration of your intellectual property strategy, your R\&D timeline, and your center of gravity, indicate with whom it would be best to partner.

\begin{tabular}{|l|c|c|c|}
\hline & Application 1 & Application 2 & Application 3 \\
\hline R\&D readiness & 1st & 3rd & 2nd \\
\hline $\begin{array}{l}\text { Market } \\
\text { responsiveness }\end{array}$ & $\mathrm{L}$ & $\mathrm{H}$ & $\mathrm{H}$ \\
\hline $\begin{array}{l}\text { Emerging or } \\
\text { Dominant design }\end{array}$ & $\mathrm{D}$ & $\mathrm{E}$ & $\mathrm{E}$ \\
\hline Market size & $\$ 50$ million & $\$ 500$ million & $\$ 750$ million \\
\hline Finances required & $\$ 3$ million & $\$ 10$ million & $\$ 20$ million \\
\hline
\end{tabular}




\section{Conclusion}

The value of your technology does not lie in the possibilities-but in the decisions that you make and the actions that you take to realize the opportunity. $A$ strategic plan starts with analysis-but must end in action in order to be of any value.
Many ATP-funded companies are developing rich technology platforms that have the capability of having a profound impact on multiple industries. The purpose of this chapter has been to introduce the reader to ways of partitioning an opportunity for maximum exploitation, as well as ways of deciding which constellation of strategies to use with each of the upstream and downstream opportunities identified.

Choice and sequencing of strategies requires careful consideration to the trends and structure of each relevant industry.

The aim of the next three chapters is to provide the reader with more advanced, in-depth information on three strategies: licensing, R \& D partnerships, and equity investment. ATP-funded firms are often quickly confronted with the need to make a choice regarding financing options, so the objective of these chapters is to better prepare the reader for the types of considerations required. 


\section{Licensing}

Advanced ORganizer

WHY COMPANIES LICENSE IN

WHAT IS A LICENSE?

HOW DOES ONE MAKE MONEY

FROM LICENSING?

DIFFERENT TYPE OF LICENSES

PREPARATION FOR LICENSING

ELEMENTS OF A LICENSING

PACKAGE

BUSINESS OPPORTUNITY PREVIEW

ASSESSMENT OF POTENTIAL LICENSEES

NEgOTIATION ISSUES

CONCLUSION 


\section{Advanced Organizer}

Many small firms select licensing as their commercialization strategy of choice, after concluding that they don't wish to act as a manufacturer, marketer, or distributor.

Although it is important to recognize and understand your interests, your firm's approach to licensing will be more comprehensive and successful if you view licensing as the conscious choice to provide one or more entities with the right to exploit your technology for mutual gain. When viewed in this fashion, you will become more concerned about the selection of an appropriate licensee, as well as the best method of structuring a mutually beneficial relationship. The word "selection" is not meant to imply that potential licensees line up to court a technology entrepreneur. In fact, the reverse is often true. Nonetheless, the word "selection" appropriately conveys the care and considerations that you should make in looking for potential licensee(s). Remember: licensing doesn't just happen. It requires considerable planning and resources.

This chapter is organized around the themes represented in Figure 5-1.

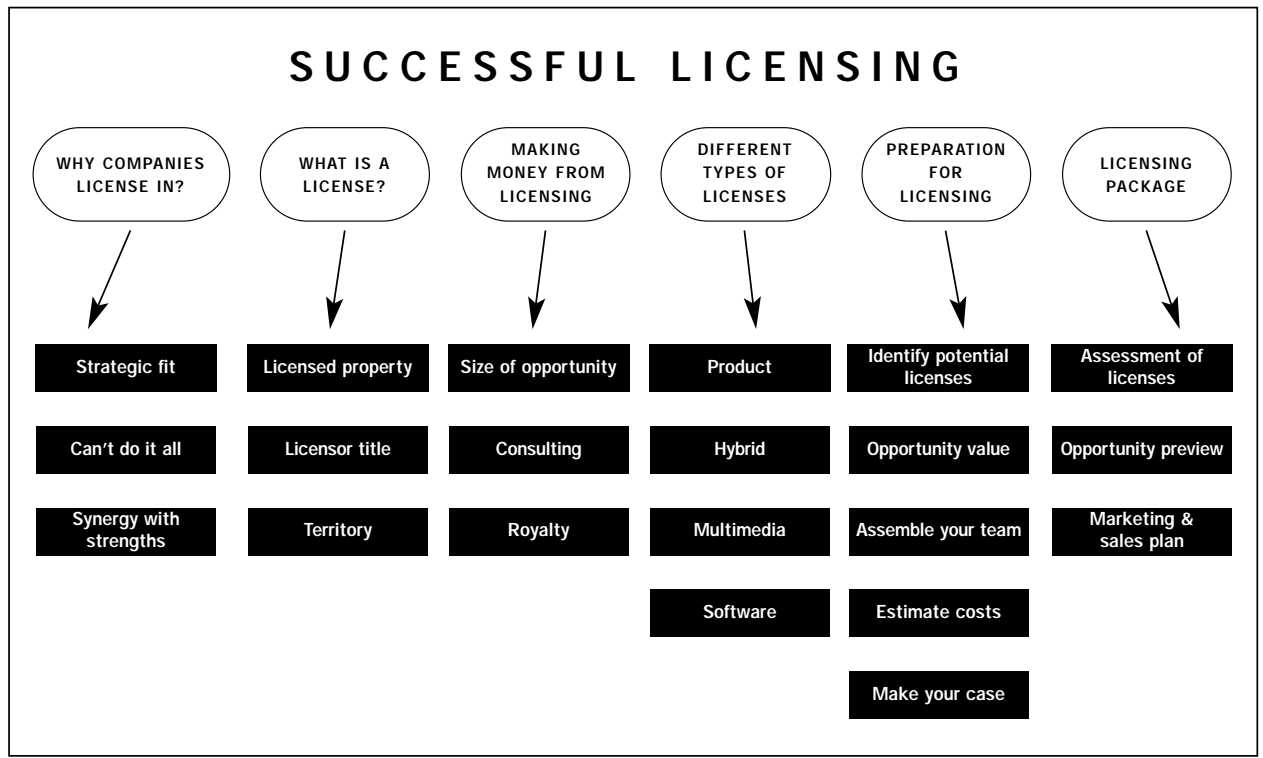


Licensing-in describes the process of obtaining rights to use the intellectual property of others, external to a company.

Sources of Information about $R \& D$ available for license:

\section{- Universities}

- Manufacturers

- Trade shows

- Patent searches

- Scientific literature

- Agents

- Licensing events

- Unsolicited contacts

\section{Why Companies License-In}

Licensing-in is a unique form of sales in which the inventor/technology entrepreneur provides the potential licensee with a compelling reason to license his or her technology. To effectively make your case, it is important to understand why a potential licensee would be interested in licensing-in. Companies are interested in increasing their assets. Intellectual property (patents, copyright, trademark, trade secret, know-how) are considered assets-but intangible and risky ones with poor, if any, liquidity. The dilemma, however, is that such assets are essential for future corporate growth (Parr, 1990). Larger firms invest as much as $10 \%$ of sales on R\&D. "The cost of original research is high and therefore requires maximum market penetration to pay for it" (Andonian, 1989). If a company can decrease the costs associated with strategic R\&D and at the same time minimize risk, licensing-in becomes an appealing option.

\section{Strategic Fit}

Technology will be licensed-in or acquired by a firm if it meets a strategic interest that the company is not capable of addressing on its own. In all cases, if a potential licensee can do the development work better itself, it has no desire to look outside. Pioneer technologies present a novel opportunity, however. In such cases, there is an increasing trend toward financing options that share risk. According to Teece (1991), these include the following:

D R\&D joint venture with Option to License

- R\&D joint venture with Option to Purchase

- Strategic alliances

When licensing is the option of choice, the intellectual property being considered must offer the licensee one or more of the following advantages. The intellectual property should (1) present a new business opportunity to the licensee which builds on its core competencies; (2) provide better access to markets that the licensee wishes to penetrate; (3) offer additional products to sell through existing distribution channels; (4) preclude other organizations from having access to the technology; and/or (5) decrease production costs.

When presenting your opportunity to a potential licensee, you must therefore make your case in consideration of the potential licensee's strategic intent. You must examine the licensee's priorities and demonstrate how your technology would meet the licensee's strategic goals. Such information about publicly traded companies is readily available. Sources that can be consulted in assessing potential licensees will be addressed in Section 2.

L I C E N S I N G

(c) DAWNBREAKER PRESS, 1998 


\section{Outsourcing $R \& D$}

A company actively looking to license-in technology has many choices.

Technology Acquisition

Representatives of a firm can look for technology from universities, other manufac-

Process

turers, and agents. They can find out about opportunities through an examination of patent and scientific literature, attendance at trade shows, and/or participation in meetings of the Licensing Executive Society. It is important that technology entrepreneurs recognize that large firms dedicate limited resources to such search activity; that their searches are strategic in nature; and that there are many sources to which they can turn. The bottom line is that in order to make your case, you need to be well prepared.

From the licensee's perspective, the Technology Acquisition Process (Manfroy et al., 1989) features a number of steps, including:

- Identification of need

D Technology sourcing

- Technology assessment

- License negotiation

- Financing

- Transfer of technology

- Implementation

- Termination of license

\section{Synergy with Strengths}

From the preceding list, three general categories of concerns are recommended for the licensee to consider relative to technology assessment: technology concerns, market concerns, and overall concerns. The licensee should assess the new product or processes and its relationship to the licensee's technology strength. The firm must also assess issues pertaining to potential implementation, including the numbers and types of employees involved, the feasibility and costs associated with manufacturing, and how much additional funding is still required. On the market side, the company must assess potential sales, profits, use of marketing, sales and distribution channels, and competitive advantage. Overall, the fit with the company's strategic direction and risks must be examined.

Because the Technology Acquisition Team has to sell its management on the merits of the technology of interest, it is important that a potential licensor make it as easy as possible for the potential licensee to buy, by addressing its needs. Also, to assure that a win-win situation is achieved, it is important that you have a means of assessing the value of what you are presenting — and that you understand the various aspects of licensing negotiation to which you will be exposed. 
The balance of this chapter assumes that you have already determined that licensing is one of the best ways to exploit the market potential of your technology. As such, it is assumed that your objective in reading this chapter is to understand more about what is involved and how to prepare for successfully locating a licensee.

\section{What is a License?}

Formally speaking, a license is "permission granted by an owner or inventor, generally for a consideration, to a person, firm, or corporation to use the owner's proprietary information, invention or material" (Goldscheider, 1993). All forms of intellectual property can be licensed, including patent, copyright, trademark, trade secret, and know-how. The nature of the "use" granted in the license varies and can include manufacture, use, lease, sale, distribution, or any combination thereof. When the owner of intellectual property grants a license to another entity, it retains ownership or title to the intellectual property. An initial word of caution: the definitions of all terms used in a licensing agreement need to be carefully consideredespecially those associated with the licensed property, the licensor, and the licensee.

\section{Definition of Licensed Property}

The licensed property should be defined with great specificity. Registered items (trademarks, copyrights, and patents) should include the registration number (Epstein \& Politano, 1995). There are a number of situations where exceptional care should be taken in drafting the definitions. Biotech is a most noticeable example. Fordis and Griffen note that difficulties arise because: (1) many biotech products are not the subject of issued or pending patents; and (2) there are a number of ways to define the biotech products. Special care should also be taken in licensing computer software: it should be made explicit as to whether or not the license applies to both the object and source code.

A single license may be drafted to cover one or multiple products/technologies and various forms of intellectual property. "The more restrictive the definition of licensed products, the smaller the potential royalty base" (Greeley, 1990). You

Ownership issues are not always straightforward. should expect there to be a natural tension in licensing negotiations, as each party is motivated to obtain what is best for the organization it represents.

\section{Licensor Title}

The licensor must have clear title to the rights it is conveying. This may seem straightforward and self-evident. However, when dealing with biological materials, especially those derived from humans, the issue of ownership is complex and often 
disputed (Fordis and Griffen, 1991). Sometimes, to avoid any infringement issues, a potential licensee may conduct a right-to-use study in order to assure clear title (Greeley, 1990).

Of equal importance is the consideration given to the definition "licensee." The licensor must be certain that he or she understands whether or not the term licensee is extended to subsidiaries, related companies, and affiliates, or strictly to the entity named. When specifying whether the license is exclusive or non-exclusive, the licensor should carefully attend to the implications that this statement has for his or her own work. Most licensors don't intentionally wish to exclude themselves from being able to make use of the intellectual property. However, this could inadvertently be the result of carelessness when granting an exclusive license. The rights of the licensor should be clearly stated in an exclusive license. Often a licensor may grant an exclusive license, but one that reverts to non-exclusive status if certain conditions are not met.

\section{Territory}

Territory deals with the specific geographic area to which the license applies. It should be noted that a license could vary from narrow use-one that is restricted to one site or plant at a specific location-to one that is global in scope.

Within a licensing agreement, many other issues are important to address. These include Indemnification, Arbitration, Best Efforts, Technical Information, Assignability, Sublicensing, Rights \& Remedies, Termination, Approvals, Changes, Technical Assistance, and Improvements, among others. Such issues require careful attention by both parties (Goldscheider, 1993). Always be sure that you understand the full implication of everything in the agreement and seek appropriate counsel.

\section{How does one make money from licensing?}

The most common form of remuneration is a royalty. Royalties may take many different forms, including running base, lump sum, or prepayment-of-running royalties. Royalties can be calculated at a constant rate, change over time, and/or specify mandatory minimum and/or maximum payments.

\section{Size of the Opportunity}

The manner in which the royalty rate is derived depends upon many factors, including industry standards, the degree of development, the magnitude of the licensed property, and market potential (Parr, 1990). Many technology entrepreneurs approach licensing with the mistaken belief that they don't need to 
understand the market, assuming that that's the licensee's job. As a result, the importance of "sizing the profitability pie" must be stressed (Epstein and Politano, 1995). With the exception of the progenitor of the technology, you should expect that everyone else who becomes involved with the technology is interested in its potential to generate wealth. According to Epstein and Politano, "Unless substantial benefits (profits) can be made, there is no point in making a deal." Estimating the size of the pie is a way of determining whether the deal is worth pursuing.

Epstein and Politano name six items that should be considered when sizing an opportunity. These include: market size, stage of market development, special status of technology in question (e.g., a pioneer patent), economic health, benefits from association with licensor, and synergy with licensee's marketing, sales, and distribution strengths. Prior to making his initial approach to the licensee, the licensor should have addressed these issues and should be prepared to make the case that there is an opportunity that can be exploited for mutual benefit. Don't expect the potential licensee to do this for you. In order to structure a "win-win" deal, both parties need to be prepared.

Another element of preparation is understanding the relative contributions both parties will make. There is often the tendency for technology entrepreneurs to overestimate their technology's contribution. This assumption often reflects a lack of understanding of what the licensee must add to the mix in order to commercialize the technology. Factors that strengthen the licensor's bargaining position include the following:

- A positive track record as an experienced and valued licensor

D R\&D-generating capability (a good facility with a rigorous R\&D program)

D Items that contribute to goodwill, such as trademarks

- Related patents, trade secrets, and know-how

- A reputation for enforcing patents against infringers

The licensee's bargaining position is augmented by the amount of risk it assumes, as well as its established manufacturing, marketing, and distribution capabilities.

\section{Consulting}

Another way for the licensor to accrue more value from the licensing relationship is to limit the technical, sales, and service support provided as part of the licensing agreement (Greeley, 1990), and to instead offer these services-when provided above a certain level-as consulting services, through an annual retainer or per diem (Epstein and Politano, 1995). If the licensor has marketing strengths, it could also seek to retain marketing rights on excess production of the licensee in areas that it does not serve. 


\section{Royalty Rates}

It is debatable as to what is the best approach to calculating royalties. The base to which royalty rates are applied can include: (1) net or gross profit; (2) net or gross sales price; (3) the gross production of the licensee. The method of calculating the royalty rates also varies. Regardless of its shortcomings, one of the most commonly used methods is comparison with industry standards. It is important to recognize that these standards vary widely. Table 6-1 provides a summary of a number of different types of standards:

\section{TABLE 5-1: SAMPLE INDUSTRY STANDARDS IN SELECTIVE FIELDS}

Chemicals (Epstein and Politano, 1995)

$1-3 \%$ of net sales for low margin items

Computers (Epstein and Politano, 1995)

$3-5 \%$ of net sales

Pharmaceuticals (Fordis and Griffen, 1991)

Research reagents (expression vector, cell culture) $1-5 \%$ of net sales

Diagnostic products (monoclonal antibodies, DNA probes) 5$8 \%$ of net sales

Therapeutic products (monoclonal antibodies, expressed proteins) 5$10 \%$ of net sales

Vaccines (5-10\% of net sales)

Animal health products (3-6\%of net sales)

Plant/ agricultural products (3-5\% of net sales)

Semiconductors (Epstein and Politano, 1995)

1.75 to $3 \%$ of net sales

\section{Types of Licenses}

There are many types of licenses. They reflect differences in both the "use" and the "type" of licensed material. A sampler of licensing agreements-product, hybrid, multimedia, and software-follows, with brief definitions of each.

Factors Affecting Royalty Rates, by McGavock, Hass \& Patin--les Nouvelles, June 1992. 
From a licensor's perspective, "best efforts" with respect to marketing and sales is not a viable option.

\section{Product License}

A product license is appropriate in the prototypical situation in which a licensor grants to the licensee the right to make, use, or sell a defined "Product." In such an agreement, items typically specified are the application of the product, any territorial restrictions, the time frame, and whether or not the license is exclusive or nonexclusive. Villeneuve $e t$ al. point out a number of areas of caution in negotiating such licenses. These include: (1) the royalty base; (2) the inclusion of technology, rather than only products; (3) the importance of marketing obligations of the licensee in exclusive licensing arrangements; (4) sub-licensing; and (5) grant-backs.

As indicated earlier, the base to which royalties are applied may vary. It is therefore very important that you are clear regarding the definition of the base, and that you also probe to assure that the base fits all intended applications by the licensee. For example, assume that you have negotiated a royalty based on the sale of the licensed product. This does not entitle you (unless specified) to benefit from revenue made by the licensee in providing a service in which he utilizes the licensed product. This is because the royalty base was defined in terms of sales of the product and did not specify revenue generated from services in which the product was used.

A licensee tries to obtain as much value for its organization as it can from an agreement. Therefore, it is common for the licensee to push to expand the domain of licensed property. The licensor must carefully consider the implications of what is being asked for. Assume, for example, that the licensee wishes to add to the product license and gain access to know-how, trade secrets, and patents owned or controlled by the licensor presently and in the future. The implications are profound. First, with respect to your future technology developments, you would be providing these to the licensee in this one agreement and would thereby limit your future business options. Second, such statements have implications for any licensed-in technology you have. By virtue of having "control" over patents you are licensing from others, you may be obligated to sub-license these as well (Villeneuve et al., 1995).

The third area of negotiation requiring caution is with respect to exclusive licenses. The licensor will not benefit from an exclusive license if the licensee does not make significant marketing and sales. Therefore, the licensor should carefully attend to the licensee's marketing obligations_-going so far as to specify the nature of the actions to be taken by the licensee. This is better than settling for the "best efforts" obligation. Another way to assure that the licensee makes significant efforts is to require a significant upfront payment as well as minimum royalty payments. The licensee will only recoup these expenses if it makes sales. When there is a financial penalty for failure to attend to marketing and sales obligations, it is less likely that marketing and sales will be given short shrift.

L I C E N S I N G

(c) DAWNBREAKER PRESS, 1998 
Another item meriting careful consideration is sublicensing. Sublicensing refers to granting to a licensee the right to license to a third party. This provides the licensee with the right to have things made, used, or distributed by others.

However, this may not be beneficial to a licensor. A license can therefore indicate that no sublicensing is permitted without prior written approval of licensor, or that the licensee may sublicense subject to meeting specific conditions (Goldscheider, 1995).

The final situation to be considered is the area of improvements and grantbacks. When you are dealing with dynamic forms of intellectual property (e.g., trade secrets and know-how), it is reasonable to assume that this body of knowledge will grow. The question becomes who receives the benefits of this growth. If the licensee is given the rights to use the technology, it is very likely that the licensee will discover new knowledge. It is, therefore, common for a licensor to seek a "grantback" of any improvements in the initial field of use. The terms and conditions associated with this are subject to negotiation (Goldscheider, 1995).

\section{Hybrid Licensing Agreement}

A hybrid licensing agreement is one which includes "a license for an issued or pending patent, together with some other form of intellectual property rights that is not coextensive with the patent" (Goldscheider, 1995). Such licenses present a new issue: what do you do if a pending patent that was part of an agreement does not issue? In such a situation, it is suggested that the royalty rate be decreased.

\section{Multimedia Licenses}

Multimedia licenses are complex because of the variety and sheer number of intellectual property items included. Multimedia products typically include text, movie images, still images, music, audio, and computer software-all of which are subject to copyright and other forms of protection. Epstein and Politano point out that a multimedia developer may need to negotiate over a hundred separate agreements in order to obtain all of the rights needed for one multimedia product. The other factor that makes multimedia licenses difficult to negotiate is that many content developers ask unreasonable and prohibitive fees, making such projects untenable. (See Smedinghoff, 1998, for a detailed treatment of the legal issues involved with licensing multimedia products.) 
Licensing Package ${ }^{T M}$

- Licensee Assessment

- Business Opportunity Preview

- Negotiation Issues
Selecting a Good Licensee?

- Strategic fit

- Can they do it better on their own?

- Financial resources

- Synergy

D NIH

\section{Software License}

Given the dynamic nature of the software industry, software licenses present many special considerations. These include: (1) rights to updates and new releases of the software; (2) testing and development support; (3) whether or not source code is included; and (4) royalty payments. If, for example, a software developer is trying to promote a new industry standard, it is not uncommon for it to provide a non-exclusive license (Villeneuve et al., 1995) and accept a flat fee, rather than an ongoing royalty. (See Villeneuve et al. for a more detailed discussion of this topic.)

Most mass-market software is distributed with shrink-wrap licenses. These licenses indicate that, by virtue of opening a certain package, users accept the terms of the licensing agreement. This is done because it is not feasible to obtain a signed license agreement from every user (Epstein and Politano, 1995).

Another type of license referred to as a run-time license is used with "authoring tools." These are used in the development of multimedia products, and are required for use of the final multimedia product.

\section{Preparation for Licensing}

The intricacies of licensing are important to understand if you don't want to walk into negotiations blindly. Any company interested in licensing-in has developed a method for examining opportunities which may meet its strategic needs, as well as a method for assessing its opportunity potential (Manfroy et al., 1989). You should do no less, especially if licensing is going to be the primary commercialization strategy used by your firm. Specifically, you should pursue the following steps:

- Identify a potential licensee

D Assess the ability of the licensing opportunity to generate value

- Put together your negotiation team

D Estimate the costs of the effort

- Make your case

- Negotiate a license

- Determine financing

- Implement the license

D Terminate the license 


\section{Identifying a Potential Licensee}

When searching for a potential licensee, it is important that what you have to offer fits with the partner's strategic direction; also, that it falls into an area where the potential licensee cannot do it better on its own. Furthermore, the potential licensee must have financial resources available, have a good sales and distribution network, and not an excessive dose of the Not Invented Here syndrome. These are the same factors Manfroy et al. suggest the licensee consider about its organization before starting down a path. In this "lock and key" situation, each of you has part of the solution and each is looking for an entity to fill the complementary role.

The Workbook in this Guide addresses in great detail the methods and resources for collecting information on potential licensees. You have limited time and resources available for your endeavor, and you need to expend your resources on appropriate prospects. Identification of Potential Licensees is the first element of the Licensing Package ${ }^{\mathrm{TM}}$.

\section{Assessing the Ability to Generate Value}

The inventor of a technology wants to see it utilized, and often perceives licensingout as a means of doing this and completing a cycle. However, if the inventor intends to become involved with licensing as a strategy of choice that he will use frequently, he must attempt to develop some objectivity concerning the technology. Does this opportunity have the potential to create significant value? Not all inventions do, and those which don't are often not good candidates for licensing. Methods for assessing the size of the opportunity are presented in the Workbook. If an opportunity exists, we recommend putting together a Business Opportunity Preview $^{\mathrm{TM}}$ to share in total or in part with a potential licensee, once appropriate Non-Disclosure Agreements have been signed. A Business Opportunity Preview is the second element of the Licensing Package ${ }^{\mathrm{TM}}$.

\section{Putting Your Team Together}

You need a negotiation team that you can draw upon at the appropriate times. You will most likely need the services of an attorney, a negotiator, and someone who can assist with valuation - and you should anticipate the costs associated with their efforts. 
Licensee Introductions

- Colleague

D Consultant

- National events

D Professional meetings

- Trade shows

- Unsolicited inquiries

\section{Estimating Costs and Pay-Back}

As was mentioned at the outset, licensing is a unique form of sales. As such, it has associated expenses. It is recommended that you develop a marketing and sales plan specifically for licensing the technology in question, to assure that you anticipate both the time and the expenses associated with the effort. Out-of-pocket expenses will include travel to the potential licensee's site, the development of presentation materials, and the costs associated with putting together your licensing team. In addition, you should factor in the time that you will need to devote to this endeavor.

When in the midst of negotiations, carefully consider the implications of all the items that have a price tag associated with them. Such items include indemnification, maintenance of patents and responsibilities relative to infringers, technical assistance, and travel.

Carefully consider how to create the best revenue stream for your company and a win-win situation for both you and the licensee.

\section{Making Your Case}

Once you have selected the appropriate domain of potential licensees and developed the materials to be used in making your case, you should determine the best approach to a potential licensee. Common choices include introductions by a colleague or consultant, participation in national events that focus on licensing and/or professional meetings and trade shows, and submission of unsolicited inquiries. Although some people recommend making inquiries sequentially, it is often best to start interacting with a number of relevant prospects simultaneously. This goal is not to play one potential licensee off of the other, but simply to make the most of what is usually a limited market window of opportunity. Once a potential licensee shows interest—and perhaps requests a "stand-still" agreement-then you can focus your efforts on that one party.

The importance of making a compelling case to potential licensees cannot be underestimated. You don't have to divulge a lot of information about what you have, but in your initial approach you should demonstrate an understanding of their strategies, their needs, and the manner in which what you have can further their aims.

This is important, because most large companies erect a large initial hurdle to potential licensees. They routinely request that interested parties sign a disclosure document indicating that everything that is shared with them they are free to 
use. Some companies will only interact with outside sources after a patent has been issued for the invention in question. The reason for this behavior is that the first priority of any large company is to protect its assets. Large firms with a strong emphasis on R\&D have hundreds of research projects on-going at any given point in time. No single point of contact could possibly have the knowledge of the breadth and diversity of projects in-house. For this reason, when first contacted, any large firm will routinely provide an inventor with a disclosure document indicating that whatever the inventor shares with the company, the firm is free to use. This is done to protect the company from possible lawsuits that could arise if someone submits an idea to the company which is rejected, and on which the company is already working. The inventor could incorrectly conclude that his or her idea was stolen because of the timing of the product release subsequent to his or her inquiry. For large firms, safety comes from adopting a set of procedures and protocols that minimize the likelihood that these types of situations will arise. That is why you have to work hard to create initial interest.

You need to decide at the outset what information you will disclose readily and what information you need to hold back until the potential licensee has signed a confidentiality agreement.

\section{License Negotiation}

Much was said earlier in the chapter about issues to be addressed during negotiations. Before getting to that point, however, the company will conduct due diligence on the technology and the market. During this period it is important that you provide the potential licensee with information that they can use to sell up-line. It is vital to the success of the project that many champions are formed along the way. A well-developed Business Opportunity Preview can serve that need.

The following account from an executive experienced with high-tech licensing matters highlights many aspects of the attitude you want to bring to the table during licensing negotiations. 


\section{ATTITUDE IS EVERYTHING}

In the following excerpt from an interview with Mike Weiner, Chairman and Founder of Manning and Napier Information Services-and previously the Founder and CEO of Microlytics, a Xerox spin-off-it becomes clear that success depends more on your attitude and attention to detail than on what you think you can do than on what you are told the rules are. There are always exceptions to the rule!

I began to use personal computers at Xerox, and then moved into the software marketing business. I found that the company wasn't taking advantage of its software assets, and I wanted the opportunity to take some of its assets outside. I kept looking for people in the company who were supportive of my idea and ignoring those who were opposed. Most were opposed.

Unlike the employees who left to form companies such as Adobe, 3COM, and others, I was able to form a unique relationship with Xerox where Microlytics would have an arms-length relationship with Xerox and license software that was underutilized and not of strategic interest. I have a no-fee consulting arrangement with the company that allows me access while assuring confidentiality. Having an outlet such as Microlytics is useful to a large firm. Technology assets are like milk. If you don't do something with them on a timely basis, they spoil.

We have had several licensing arrangements with Xerox. Our initial license provided Microlytics with broad sub-licensing rights that were pivotal to our early success. We went from $\$ 3$ to $\$ 14$ million in three years. During the past 10 years, we have dealt with the same corporate staff and the same RED staff and maintained excellent relationships.

In looking at what makes licensing successful, there are many factors. On many occasions employees who leave a large company become very arrogant in their dealings with the firm. That is counter-productive. Xerox is like family, and there is a tremendous amount of informal networking that takes place.

What we tend to do in our negotiations is to be sure that we understand the issues of concern to the company with whom we are negotiating and address those issues.

During licensing negotiations with any firm, if you agree to something in your verbal conversations, it is your obligation to address any omissions that you see in the written document-omissions which not only favor you, but also omissions which favor your negotiating partner. There must be reciprocity. You must be straight.

Issues regarding "know-how" are addressed up front. We also negotiate "flowback" rights and specify which divisions get the rights in "licensing-back" arrangements.

Many times what we will do is select a company which we think will be the best possible partner and offer the company a "no-cost, stand-still agreement" (30-60 days). 
This allows the internal champion the time and incentive to try and gain a corporate commitment. However, this offer has to be genuine on your part, and not a ploy.

In negotiations, it helps to be high-minded. Be consistent and over time many of your partners will become that way also. However, it is imperative to review carefully any licensing agreement that you sign. You can never have too many eyes looking at a document.

We have also walked away from deals because we have assessed the guys we are dealing with to be disreputable.

I would recommend to anyone entering a licensing arrangement that he should start by thinking about and defining the nature of the relationship that he wishes with a licensee. Begin to act as if you have that type of relationship-model it in your actions. Then articulate to the potential licensee what relationship you want. Attitude, more than anything else, determines outcome. Also, above all, for an inventor or an entrepreneur, consistency, credibility, and integrity are your greatest assets. Don't forget what you have agreed to.

When licensing arrangements go bad, it is usually because the licensee finds or develops an alternative technology, and then devalues yours; or management changes and doesn't know about the relationship-or devalues it. Or it's due to buyer's remorse or greed and avarice.

However, you should keep in mind that it is hard to unseat the status quo and, if you are, work hard to maintain those relationships and your position.

Scientists and engineers want to see their ideas and inventions validated and come to fruition. Corporations which don't provide this run the risk of frustrating their best and brightest. Yet most companies cannot hope to market all the productive output of a bright and creative workforce. This is where an employee intrapreneurship and a licensing-out policy can pay substantial dividends, including reduction of employee turnover.

\section{Implementation}

During the implementation of a license, you should continue to monitor the extent to which the terms of the agreement are being met. As the summaries below reveal, failure to raise issues early can lead to unforeseen difficulties. 


\section{RELEVANT LEGAL CASES}

\section{Introduction}

In this section, we present a sample case in which contractual licensing arrangements deteriorated and resulted in litigation. In this case, intellectual property protection was granted at the Federal level.

\section{CASE 1: Coleman v. Corning Glass Works}

(U.S. District Court, Western District of New York, 1985)

Dr. Coleman, the owner of a U.S. patent, entered into a licensing agreement with Corning Glass Works, granting Corning an exclusive license for the commercial development of a commercial integrated blood serum separator under his patent. Corning terminated the agreement three years later, alleging that a commercial, functioning blood separation machine could not be made in accordance with Dr. Coleman's patent. Allegedly, independent research by Corning had also resulted in the development of a superior approach to designing a serum machine.

Corning continued development of its serum machine, the "Corvac Serum Machine," and began production in 1975. Corning then sold the entire product line to Sherwood Medical Industries three years later.

Dr. Coleman alleges that the blood separation device manufactured and sold by Corning (the Corvac Serum Machine) was within the scope of his original patent. Corning moved for summary judgment on the grounds that the plaintiff was too late in bringing this suit (16 years after the initial licensing agreement was signed).

The court agreed with Corning, and Dr. Coleman lost the suit on the grounds that he was too late bringing suit.

\section{Some Lessons to be Learned by Independent Inventors}

- Plan for what each party can or cannot do with shared information if a signed agreement is terminated.

- Act sooner, rather than later.

- Be sure of which statutes of limitations may be applicable.

\section{Some Lessons to be Learned by Corporations}

- Good documentation is required of independent creation.

- Act in good faith and try to structure "win-win" situations. 


\section{Elements of a Licensing Package ${ }^{T M}$}

A Licensing Package is a means of compiling pertinent information that you will need during the licensing process. It should contain the following three components:

(1) Business Opportunity Preview ${ }^{\mathrm{TM}}$

(2) Analysis of Potential Licensees

(3) Negotiation Issues

Activities designed to surface the information needed to develop each section of this package can be found in the Workbook in this Guide. Each of these elements will be used in a different way. The Business Opportunity Preview ${ }^{\mathrm{TM}}$ is the document used to make your business case. It clarifies the nature of the opportunity at hand. The Executive Summary should not contain any proprietary information, and should be used in your initial interaction with a potential licensee when your discussions are not covered by a Confidentiality Agreement. The balance of the document can be used in part or in its entirety, once you have clearly established the interest of the potential licensee. Much of the information should only be shared with a potential licensee once a Confidentiality Agreement has been signed. However, you may find it necessary to share elements of this document with a potential licensee prior to signing a Confidentiality Agreement, in order to enable him or her to sell up-line. Information that demonstrates that you understand customer specifications and that demonstrates customer receptivity to the product is often appropriate to share. A suggested outline for a Business

Opportunity Preview ${ }^{\mathrm{TM}}$ follows.

\section{Business Opportunity Preview ${ }^{\mathrm{TM}}$}

\subsection{EXECUTIVE SUMMARY}

1.1 Description of industry

D Overview

- Industry drivers \& issues

- Opportunity \& threats

1.2 Technology available for Licensing

- Brief description

1.3 Licensing arrangement

- Types of partners sought

- Types of arrangements

(continued on the next page)
This is a suggested outline, and is not meant to be a straight-jacket. In some situations, a more compelling case can be made if the information is sequenced in a different fashion. The overriding concern is not the form, but the presentation of a believable case given the size of the opportunity. 


\subsection{COMPANY \& TECHNOLOGY}

2.1 Brief company introduction

- Mission

- Location, size, history

- Overview of company capabilities

- Management Team

2.2 Technology/ product description

- Detailed description

- Present state of development

- Intellectual property

2.3 Related technology (only if appropriate)

3.0 CUSTOMERS

3.1 How need is currently filled

3.2. Important product specs and features

3.3. Degree of customer interest

3.4. Decision-makers and influencers

3.5. Basis for purchase decision

- Frequency

- Timing of purchase decision

4.0 MARKET

4.1 Market definition

- Market segmentation

Across applications (if appropriate)

Within applications

\subsection{Market Size}

- Served available market

- Rate of market growth

5.0 COMPETITORS

5.1 Indirect \& Direct competitors

5.2 Competitive advantages

- Features, Advantages, Benefits 


\section{Assessment of Potential Licensees}

The second element of the Licensing Package is referred to as the Assessment of

Potential Licensees. This document is for your internal use only, and is intended to prompt the capture of all relevant intelligence needed in determining the domain of potential licensees to approach. You should plan on selectively using information from this document in your discussions with potential licensees, or use an Executive Summary to reflect your understanding of the potential licensee's direction. Consult the Workbook for guidance on how to gather appropriate information. The key thing to remember in completing these activities is that you are not looking for static information about the company, but are gathering information that will confirm to the licensee the importance and relevance of what you have to offer. You are looking to confirm synergies and availability of funds.

A suggested outline for this document follows:

\section{Assessment of Potential Licensees}

(A) Domain of potential licensees

- Candidate 1

- Candidate 2

- Etc.

(B) Candidate 1

1. Core competencies $(R \& D$, manufacturing, marketing, sales, distribution)

2. Strategic Direction

3. New business trends: Outsourcing $R \& D$, Acquisitions \& Mergers, Divestitures

4. Issues facing the potential licensee

5. Strategic advantages of your technology to the licensee

(C) Candidate 2

1. Core competencies ( $R \& D$, manufacturing, marketing, sales, distribution)

2. Strategic Direction

3. New business trends: Outsourcing $R \& D$, Acquisitions $\&$ Mergers, Divestitures

4. Issues facing the potential licensee

5. Strategic advantages of your technology to the licensee

A similar analysis can be conducted of potential strategic allies or corporate partners. 


\section{Negotiation Issues}

This third element of the Licensing Package is also a proprietary document and is directly related to your Strategic Plan. After reviewing your Strategic Plan, complete the following.

(1) Relevant Intellectual Property

1.1. Patents (issued and pending)

1.2. Trade-secrets

1.3. Copyrights

1.4. Trade secrets

1.5. Know-How

1.6 Licenses you hold from others

(2) Partitioning of the Opportunity

2.1 Upstream/downstream

2.2 Industry

2.3 Geographic location

(3) Rights You Wish to Retain

- Itemize applications

(4) Consulting and/ or Development Role

- As part of license

- In addition to license

(5) Grant-backs \& Improvements

(6) What You Are Willing to Provide

- Itemize

(7) What Licensee Would Need to Provide

- Degree of technology risk

\section{Conclusion}

Licensing is one of a variety of strategies that can be used to successfully commercialize a technology. Success in this arena requires that the potential licensor becomes skilled in locating the best potential licensee, developing a compelling case, and nurturing the relationship through the stages of due diligence, negotiation, and implementation. A company that is serious about licensing should develop a Licensing Package as a means of pulling together all pertinent information that will be needed during the licensing process. 


\section{Teaming For Success}

Advanced Organizer

DEFINITIONS

J OINT VENTURES

WHY FORM A CORPORATE

PARTNERSHIP?

WHAT ARE THE RISKS OF CORPORATE PARTNERING?

HOW TO STRUCTURE A SUCCESSFUL CORPORATE PARTNERSHIP

6

CONCLUSION 


\section{Advanced Organizer}

The expense of bringing products to market in highly competitive industries such as pharmaceuticals and semiconductors-as well as the need to accelerate product introduction and shore up competitive positions-have led many large and small firms to collaborate. Once fierce competitors, companies such as General Motors and Toyota, Siemens and Philips, and Canon and Kodak have become allies (Hamel et al., 1989). The purpose of this chapter is to examine corporate partnering, and to provide insight into when and how you may wish to consider corporate partnering as a commercialization strategy.

SUCCESSFUL CORPORATE PARTNERING
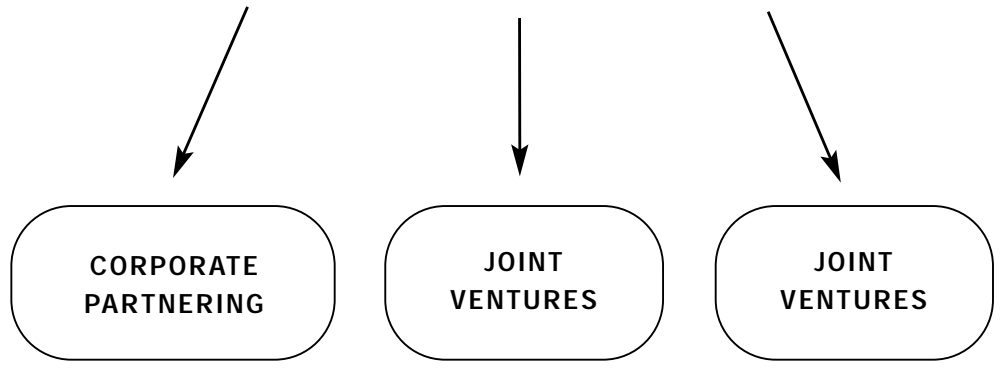

$R \& D$ agreements

Contractual

Why form?

Distribution

Agreements

Separate entity

Risks?

Manufacturing

Agreements 


\section{Definitions}

Villeneuve, Thomas, F., Gunderson J r., Robert V., and

Kaufman, Daniel M., Corporate Partnering: Structuring and Negotiating Domestic and International Strategic Alliances. Aspen Law \& Business, 1995.

This section describes partnering primarily at the later stages of $R \& D$ and for commercialization. Partnering in an ATP joint venture involves a somewhat different set of motivations and challenges, not fully covered here.

Many ATP awardees have already formed some research and development partnerships. The intent of this chapter is to provide insight into additional options.
Corporate partnering is not the same as a strategic alliance (Villeneuve et al., 1995). The former is distinguished by the presence of the following:

D Two or more organizations (e.g., a customer and a supplier or two or more competitors),

- A relationship which requires performance over time

- Two or more contractual or transactional elements, such as a licensing agreement, a research and development agreement, a distribution agreement, equity financing, a manufacturing agreement, or debt financing

D A system of interdependencies

By contrast, a strategic alliance may be short in duration, less formal, and/or contain fewer contractual or transactional elements. Some of these elements are described below.

\section{The Research and Development Agreement}

A research and development agreement is a common element of corporate partnering arrangements. Such agreements clarify the following: (1) the research and development responsibilities of each party; (2) who will fund the components of the effort; and (3) what rights will be divided among the players upon completion of the research and development. As was mentioned at the outset, corporate partnering arrangements involve a family of contractual elements. For example, it is not uncommon with pharmaceutical research and development agreements that another contractual element be a license and supply agreement. Villeneuve provides an example of a research and development agreement with an option (Villeneuve et al., Chapter 13).

Because of the risk associated with research and development activities, it is best for the developer (the junior party) to maintain its obligation level to "reasonable commercial efforts" (Radcliffe and Clowes, 1991). This is suggested because research and development outcomes cannot be guaranteed. In addition, the R\&D agreement should clarify how changes in specifications will be handled.

\section{The Distribution Agreement}

A distribution agreement is a common element of many corporate partnering arrangements between small and large firms. The smaller firm typically provides the product, while the larger company provides the distribution channel. The benefit of this arrangement to the small firm is quicker time to market and money saved

TEA M ING FOR SUCCESS

c) DAWNBREAKER PRESS, 1998 
through bypassing an investment in the development of an effective distribution channel (often an impossible task when there are strong incumbents). For the large company, the benefit comes in the form of revenue generation, which results from having new product to pump through existing distribution channels. The large company also saves money in this arrangement, by having the option to invest less in internal research and development.

Villeneuve et al. indicate that many contractual agreements are really variations of a supply/distribution agreement. These variations include the Supply Agreement, the Original Equipment Manufacturer (OEM) Agreement, the Value-Added Reseller (VAR) Agreement, and the Distribution Agreement.

In most supply agreements, the purchaser agrees to purchase and use the supplied material in the production of its own product. An OEM agreement is similar, but in this case, the purchaser typically bundles the supplied product with, or incorporates it into, its own products. Labeling needs to be clarified in such agreements. With a Value-Added Re-seller agreement (VAR), the supplier may customize the product for a specific vertical market application and/or provide the end-user with services. Under a distribution agreement, the supplied product in its original form is distributed under the supplier's trademark. An excellent example of a Supply Agreement for a biotechnology firm can be found in Villeneuve et al. (Chapter 7).

\section{The Manufacturing Agreement}

Hamel recommends a change in focus with respect to OEM agreements, especially when corporate partnering crosses international lines (Hamel et al., 1989). U.S. firms, he maintains, typically enter OEM agreements as a way to avoid costs, as well as to gain competitive edge quickly and with minimum effort. By contrast, many overseas firms enter an arrangement with the intent to learn as much as possible about their partner's customers, methods of doing business, and markets. For example, Hamel mentions that in the case of one particular alliance between a European and Japanese firm, every time the European firm asked for manufacturing design modifications to be made, the Japanese partner asked for detailed information about customers and competitors before it would respond to the request. In this fashion, the Japanese partner developed very detailed information about the marketplace. Hamel recommends that U.S. firms adopt a similar attitude toward partnering - namely, to view it as a means of strategic learning. In addition, he recommends that special precautions be taken to minimize the unwanted transfer of information.

Collaboration is competition in a different form, according to Hamel. Successful companies never forget that their new partners may be out to disarm
SUPPLIER AGREEMENT

D buyer is obligated to purchase from seller

D buyer is required to provide forecasts

- seller has delivery obligations

- product acceptance procedures are clarified

- liability and compliance requirements are clarified 
In joint ventures between software developers and computer manufacturers or operating system vendors, the senior party typically provides funding, equipment, and tools in exchange for rights to market the ported product (Villeneuve et al., 1995). them. It is therefore important that companies engaged in corporate partnerships inform employees at all levels as to which skills and technologies they should not share. In addition, companies should consider restricting access to their facilities.

\section{Joint Ventures}

Most corporate partnerships are purely contractual in nature, although some result in the formation of a new corporate entity. In contractual joint ventures, the larger company is often referred to as the senior party, while the smaller company is referred to as the junior party. The objective of the relationship is to sell product and finance additional research and development (Radcliffe and Clowes, 1991). Technology, research and development, or products are usually provided by the smaller entity, while the senior party provides financing (debt, equity, or R\&D funding), as well as services.

The allocation of subsequent manufacturing and distribution rights is another key element of the agreement. In some cases, the junior party may wish to establish and expand its manufacturing capabilities, utilizing capital from the senior party to build such facilities. It may give up marketing and distribution rights but insist that it retain manufacturing rights. Furthermore, it may insist on minimum and firm purchase orders to justify and support the expanded manufacturing capacity (Villeneuve et al., 1995). The contractual relationship between the two parties may also be useful in attracting financing from a third party.

In some situations, the joint venture may take the form of a new corporate entity. This option is typically considered when it is not anticipated that there will be significant early losses (Greeley, 1990). In such cases, the investment may take the form of preferred stock because of the preference it offers on liquidation, antidilution protection, and special voting rights. Valuation and control issues come to the foreground when a new corporate entity is formed.

\section{Why Form a Corporate Partnership?}

A corporate partnership is a competitive tool. "The challenge is to share enough skills to create advantage vis a vis companies outside the alliance, while preventing a wholesale transfer of core skills to the partner (Hamel et al., 1989)." When opportunity costs and entry risk are extremely high, it is often not feasible to conduct all development work in-house (Krubasik, 1988). In such instances, joint ventures may be the preferable choice.

According to Harrigan (1986), joint ventures provide tremendous opportunities for an organization to strengthen its current strategic platform. In emerging fields, joint ventures enable companies to:

TEA M ING FOR SUCCES S 
D influence the evolution of an industry's structure

Dre-empt competitors

D share cost and risk

D obtain additional financing

- expand corporate intelligence

D retain entrepreneurial employees

In some instances, a joint venture does not offer a fast enough response to changing conditions. Under such circumstances, an acquisition may be necessary in order to quickly obtain the desired competitive advantage.

\section{What Are the Risks of Corporate Partnering?}

Whenever an interdependency is formed, both parties assume risk. If a company of any size comes to rely upon another for a specific business function, it is unlikely to develop that capacity itself. Unless a partner makes itself indispensable to the relationship, an ally could become a competitor.

Other risks are loss of flexibility and future opportunities. This is more likely to occur with inexperienced, smaller companies which may be naive when first entering a corporate partnering arrangement. The terms and conditions of the joint venture could potentially be so inclusive as to be, in essence, an acquisition.

According to Villeneuve $e t$ al., potential investors in the smaller firms have often walked away from deals that on the surface seemed attractive, but which due diligence revealed to be little more than an research and development arm locked into a relationship with a large firm.

\section{How Is a Successful Corporate Partnership Structured?}

Corporate partnerships are not panaceas, and they require a great deal of attention to make them function well over the long haul. As with most relationships, when corporate partnerships fail, it is due to poor initial choice of partners, unrealistic expectations, poorly articulated objectives, and changes in corporate direction. When considering a corporate partnership, it is a good idea to keep in mind the strategic planning and competitive intelligence tips discussed in Chapters 4 and 5. In addition, Badaracco (1991) recommends that the following:

(1) Have a clear understanding of your company's present and future capabilities.

(2) Carefully consider the strengths and weaknesses of potential partners.

(3) Examine your own and your partner's values, capabilities, and commitment level. 
If you determine that a corporate partnership is appropriate for the commercialization of your technology platform, and if you have chosen a partner carefully, remember that the corporate partnership will take considerable time and attention to develop trust and understanding. As Badaracco notes, alliances need to be led, not just managed.

Lay the foundation well, beginning with the Letter of Intent - also called a Memorandum of Understanding (MOU) or an Agreement in Principle. The Letter of Intent should be reviewed by legal counsel to minimize delays and frustrations. Immediately after signing the letter, begin preparation and negotiation of the family of interrelated final agreements (e.g., a research and development agreement, a supply agreement, and a financing agreement). These documents are negotiated as a package, even though they constitute separate agreements. (See Chapter 1 of Villeneuve et al., 1995, for numerous tips on how to prepare for negotiations.)

\section{Conclusion}

Corporate partnering can provide many strategic benefits. In the next chapter we see that with some technologies, corporate partnering may be the only way to adequately share risk and obtain the investment required. Although the equity investment market is growing, it is focused on a limited number of markets-those that can yield a short-term payback. 


\section{Equity Investments}

AdVAnced Organizer

BUSINESS ANGELS

institutional Venture Capital

INVESTMENT BANKERS

Initial Public Offerings

TOOLS TO USE WITH EQUITY INVESTORS

WHO SHOULD DEVELOP THE BUSINESS PLAN?

WHAT FORMAT DO I FOLLOW?

Business Plan Outline (General)

Business Plan Outline (Detailed)

Executive Summary

Getting feedback on the plan

REVISING THE PLAN

GUIDELINES FOR BUSINESS PLAN REVISIONS

HOW TO USE YOUR BUSINESS PLAN

HOW TO CREATE OPPORTUNITIES FOR DISTRIBUTING YOUR PLAN

Internal VALUe of the plan 


\section{Advanced Organizer}

In Chapter 2 we offered a general roadmap to financing and discussed the relative size of different equity markets. In this chapter we provide more detailed information about how to find and approach various types of equity investors, whether they be business angels, institutional venture capital firms, or investment bankers. We also provide information on how to develop an appropriate business plan.

Regardless of which form of equity financing you choose to pursue, you will still need a good business plan. Many documents are called "business plans," but most fit the bill in name only. The basic plan, with which we conclude this chapter, has been used with over 400 small businesses. Business plans developed using this methodology are frequently rated in the top $20 \%$ of business plans seen by investors.

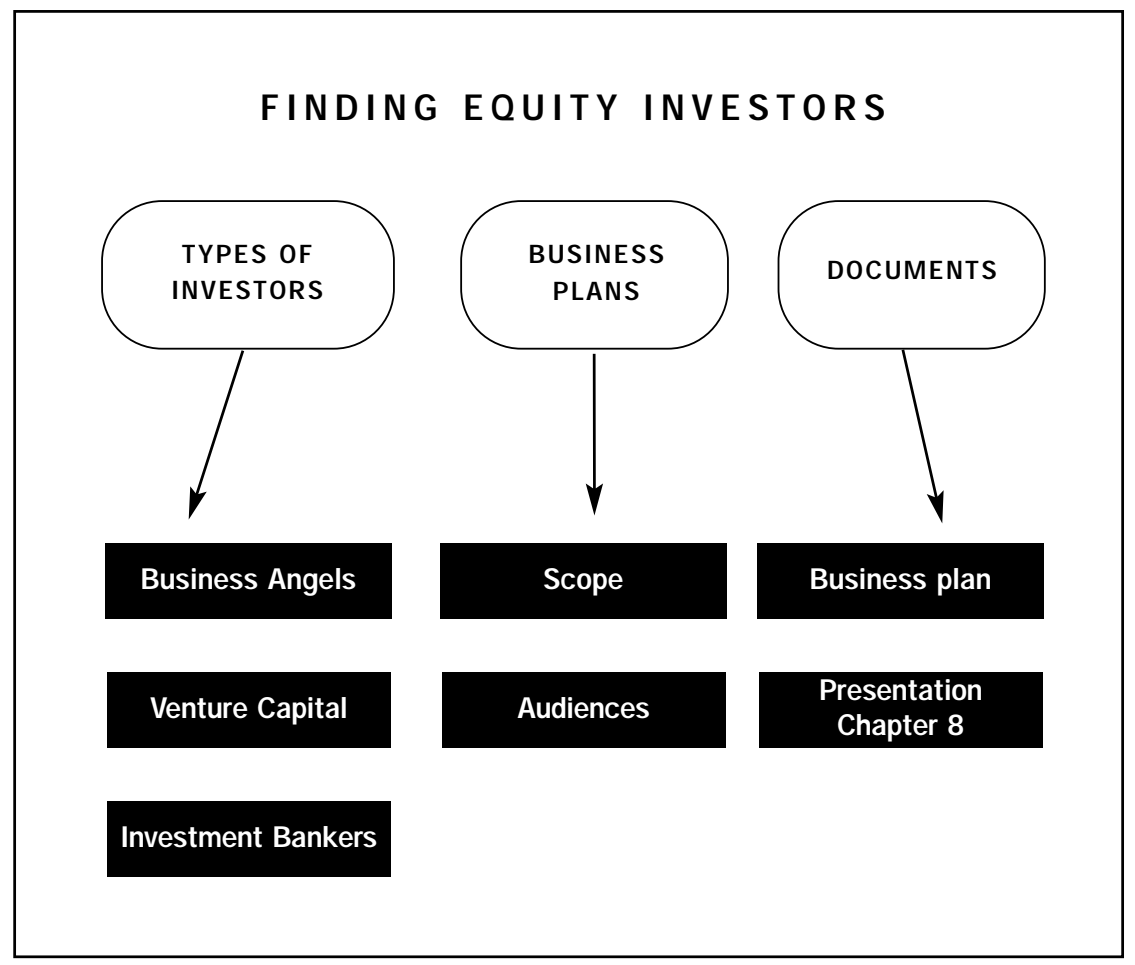

Please note that the outline for a business plan included in this chapter is intended for use in the post-ATP. award period ONLY. Please be sure to consult ATP's proposal preparation guidelines if you are preparing a business plan to include with the ATP proposal.

This chapter is intended to expand and enhance the preliminary plan developed as part of the ATP proposal into a robust operating plan which can be used for both internal and external applications. 


\section{Business Angels}

Finding Your Wings: How to Locate Private Investors to Fund Your Venture, by Gerald

A. Benjamin and Joel Margulis. John Wiley and Sons: (800) 225-5945.

Business angels invest their own money and tend to shield themselves from the barrage of needy companies. Intermediaries are frequently used as a filter.

\section{Who Should Approach Business Angels?}

As we mentioned in an earlier chapter, there are three types of entrepreneurial companies: the life-style firm, the foundation company, and the high-potential venture. Any of these entities could benefit from approaching a business angel. A lifestyle company might approach an angel for a loan, whereas a foundation company or high-potential venture might approach an angel for an early-stage equity investment. If relatively small amounts of money are needed (defined as amounts under $\$ 500,000)$, an entrepreneur might be best served by approaching a business angel.

\section{How Do You Find a Business Angel?}

Unlike banks or venture capital firms, business angels do not publish their addresses and phone numbers. Investing is not the primary activity of business angels, but something they do on the side. Angels will either seek investment opportunities on their own or work through intermediaries that serve as both buffers and filters. According to a study conducted by William Wetzel in 1984, the most common sources of referrals are friends, business associates, or active personal searches. Other, less-used sources include investment bankers, business brokers, commercial bankers, attorneys, and accountants.

How do you find an angel? Look close to home-within a 50-mile radius. Network with your colleagues. Ask your accountant, lawyer, doctor, or other successful entrepreneurs in the community who they think might invest in start-ups. Visit or call these potential investors-and take your business plan with you. You might also become a member of a computer matching service, and attend venture capital club meetings.

\section{The Technology Capital Network at MIT}

The Technology Capital Network at MIT is a database that acts as an intermediary between entrepreneurs and investors. Information on venture capitalists and other funding sources are entered into a database, along with data on entrepreneurs, for a subscription period of at least one year. Each time a new subscriber arrives, whether investor or entrepreneur, a run is made through the entire database to find matches between entrepreneurs seeking funding and investors seeking viable alternatives. Prior matches are screened out to avoid duplicate matchmaking.

Matches are made against a profile of each entrant. A questionnaire is used for both investors and entrepreneurs. Entrepreneurs must also provide a copy of the 
Executive Summary from their business plans, and one-page financials.

When a match is found, general material describing the entrepreneur and the opportunity is mailed to the matching capital sources. When the capital source(s) indicate(s) further interest, the name of each party is supplied to the other, and they are left to arrange meetings and follow up. One popular matching service is ACE-Net.

The Technology Capital Network has been at MIT since 1990. In essence, it is a transplanted version of the Venture Capital Network of the Center for Venture Research at the University of New Hampshire. The database currently contains approximately 250 names, with a ratio of two entrepreneurs for each investor. Funding of this network is accomplished through fees and sponsors. The fees are $\$ 300$ per year for entrepreneurs, $\$ 350$ per year for private investors, and $\$ 700$ a year for professional investors (both companies and venture capital funds). Sponsors include the Digital Equipment Corporation (the primary sponsor) and the Commonwealth of Massachusetts.

\section{Venture Capital Clubs}

The business angel community is quite different in other parts of the country. In New York State, for example, one can find out about meetings of the informal venture capital community by contacting any local Chamber of Commerce. Other states lack formal relationships with the angel community, however, so other approaches are required there.

To find out if there are venture capital clubs in your area, contact the National Venture Capital Association. Venture capital clubs tend to meet on a monthly basis and invite two to four entrepreneurs who are interested in raising money to come and make a 15 -minute presentation to a group over breakfast. The audience will often include many service providers, but enough business angels should be present for you to begin the process of networking locally.

\section{How Do Angels Make Money?}

Investment is not a full-time endeavor for business angels, so the angel market tends to be less sophisticated than the professional venture capital (VC) market. Nevertheless, business angels look for a Return on Investment (ROI) in a similar fashion to the VC community. Angels' terms and conditions are often more lenient than those of institutional venture capitalists. 
National Venture Capital

Association (NASBIC)

(703) 351-5267.

Be selective when

contacting institutional

investors. Contact those

venture capital firms which

invest in your:

- geographic region

- industry

- stage of development

Pratt's Guide to Venture

Capital, edited by Daniel

Bokser, Securities Data

Publishing, (800) 455-5844.

Venture Capital Resource

Library

http:/ / www.vfinance.com

\section{Institutional Venture Capital Community}

There are approximately 1,000 institutional investment companies in the U.S.

Some of these are partnerships, others are affiliated with large corporations, and still others are affiliated with the government (SBIC-Small Business Investment Corporations, and MSBIC-Minority Small Business Investment Corporations).

Such funds are usually staffed by professional money managers who make decisions regarding the investment of other people's money in businesses that have a high promise of return. The funds they invest typically come from pension funds, corporations, and insurance companies. It is for this reason that most professional venture capital funds prefer to enter at the level of Second Stage Financing, and not before.

\section{How to Find Out About the Venture Capital Community}

Venture capitalists are full-time professionals and make their whereabouts wellknown. Rather than approaching venture capitalists cold, however, it is best to have a personal introduction; also, make sure you have a solid business plan that's ready to distribute. A primary source for locating venture capitalists is Pratt's Guide to Venture Capital. This source is updated annually, and is found in the reference section of most libraries. Pratt's Guide lists investors by technology, service areas of interest, and geographic location. You will find the name, address, fax, and phone number of appropriate contacts, plus information regarding the level of investment that they make, the kinds of financials that they wish to see, and whether they are currently making any investments.

\section{Processes and documents}

Venture capitalists see hundreds of business plans in any given week. Most of the plans don't make it past a cursory review. According to Pratt's Guide, 60\% are rejected after a 20-30 minute scanning, and 25\% are discarded after a lengthier review. The remaining $15 \%$ are looked at in more detail, and of these, $10 \%$ are dismissed due disqualifying flaws in the management team or the business plan. Only $5 \%$ are considered to be viable investment opportunities and 3\% result in successful financing.

Again, your firm must have a management team before it seeks out institutional venture capital, since sole proprietorships are NOT of interest to the VC community. Your management team must have an appropriate balance of experience and authority, such that it can cover all of the following: marketing and sales, research and development, operations, and finance and administration.

E Q U I T Y I N VESTOR S

(c) DAWNBREAKER PRESS, 1998 
If you get to first base with a venture capital investor and follow due diligence, you will need to draft a number of documents as part of the follow-through process:

D Letters of Intent

- Financing Agreements

- Operating Covenants

\section{Investment Bankers}

\section{The Private Placement}

High-potential ventures and foundation companies may find private placements to be a good financing option. Private Placements and Initial Public Offerings (IPOs) involve the SEC, a quasi-judicial administrative agency of the Federal government-as well as the SEC's counterpart organizations in each state. SEC-regulated financing methods are complex, and so are best avoided by life-style firms. For an excellent discussion of this topic, you may wish to pick up a copy of The Entrepreneur's Guide to Going Public, by James B. Arkebauer.

To understand private placements, one needs to understand some of the legislative background of the SEC. The Securities and Exchange Commission was formed in 1934 pursuant to the Securities Exchange Act of 1933. The purpose of this Act was to form an entity that would guard against fraudulent sales practices, supervise the registration of securities, and regulate the over-the-counter and securities markets. The New York Stock Exchange (NYSE), American Stock Exchange (AMEX), the National Association of Securities Dealers Automated Quotation System (NASDAQ) — as well as the Over-The-Counter (OTC) markets—are all regulated by the SEC and its regional offices. The SEC and the Act of ' 33 require that when securities are sold, information be fairly and fully disclosed to the public. Companies comply in many ways, including an elaborate and expensive registration process, the preparation of a document referred to as a prospectus, and by heeding limitations on other information it may divulge once an underwriter has been signed.

Due to the inability of many small companies to participate in the costly IPO process, new legislation-the Small Business Investment Incentive Act-was passed in 1980. One of the results of the law was that in 1982, the SEC implemented an exemption referred to as Regulation D, or Reg $\mathbf{D}$ for short. It had positive implications for small business that are described in Arkebauer's book. In 1988, still other revisions were implemented, making it easier still for small businesses to engage in equity fund-raising. 
An important caveat to mention here is that every state has its own laws, referred to as "blue-sky" laws, which also affect the sale of securities. Be mindful that there are both state and federal regulations, as well as registration processes, for each. You are advised to consult a corporate attorney who specializes in SEC issues to guide you through this process.
Regulation D clarifies exemptions to the SEC regulations as articulated in the Act of ' 33 , and provides the basis for Private Placements. There are six rules that constitute Regulation D:

$\begin{array}{ll}\text { Rule 501 } & \text { definitions and terms } \\ \text { Rule 502 } & \text { conditions, limitations, and information requirements } \\ \text { Rule 503 } & \text { SEC notification requirements } \\ \text { Rule 504 } & \text { raising money through securities sales up to } \$ 1 \text { million } \\ \text { Rule 505 } & \begin{array}{l}\text { raising money through securities sales of between } \$ 1 \text { and } \\ \$ 5 \text { million }\end{array} \\ \text { Rule 506 } & \text { raising money through securities sales over } \$ 5 \text { million }\end{array}$

For detailed descriptions of each of these rules, you may wish to read Arkebauer's book and contact a regional or state SEC office for information on the registration process for Private Placements (Regulation D) and other SEC exemptions. You might also request a copy of a small brochure called Q\&A: Small Business and the SEC, from your regional SEC office. Contact information for the 12 regional offices is listed below:

$\begin{array}{ll}\text { Securities \& Exchange Commission } & \begin{array}{l}\text { Securities \& Exchange Commission } \\ \text { Northeast Regional Office }\end{array} \\ \text { Southeast Regional Office } \\ \text { W World Trade Center, 13th Floor } & \text { 1401 Brickell Avenue, Suite 200 } \\ \text { New York, NY 10048 } & \text { Miami, FL 33131 } \\ \text { (212) 748-8000 } & (305) \text { 536-4700 } \\ \text { e-mail: newyork@sec.gov } & \text { e-mail: miami@sec.gov }\end{array}$

Securities \& Exchange Commission Securities \& Exchange Commission Boston District Office Atlanta District Office

73 Tremont Street, Suite 600

Boston, MA 02108-3912

(617) 424-5900

3475 Lenox Road, N.E., Suite 1000

Atlanta, GA 30326-1232

e-mail: atlanta@sec.gov

\section{Securities \& Exchange Commission Securities \& Exchange Commission} Philadelphia District Office The Curtis Center, Suite 1120 East 601 Walnut Street

Philadelphia, PA 19106-3322

(215) 597-3100

e-mail: philadelphia@sec.gov Midwest Regional Office Citicorp Center 500 West Madison Street, Suite 1400 Chicago, IL 60661-2511

(312) 353-7390

e-mail: chicago@sec.gov 
Securities \& Exchange Commission

Central Regional Office

1801 California Street, Suite 4800

Denver, CO 80202-2648

(303) 844-1000

e-mail:denver@sec.gov

Securities \& Exchange Commission

Fort Worth District Office

801 Cherry Street, Suite 1900

Fort Worth, TX 76102

(817) 978-3821

e-mail: dfw@sec.gov

Securities \& Exchange Commission

Salt Lake District Office

500 Key Bank Tower

50 South Main Street, Suite 500,

Box 79

Salt Lake City, UT 84144-0402

(801) 524-5796

e-mail: saltlake@sec.gov
Securities \& Exchange Commission

Pacific Regional Office

5670 Wilshire Boulevard, 11th Floor

Los Angeles, CA 90036-3648

(213) 965-3998

e-mail: losangeles@sec.gov

Securities \& Exchange Commission

San Francisco District Office

44 Montgomery Street, Suite 1100

San Francisco, CA 94104

(415) 705-2500

e-mail: sanfrancisco@sec.gov 
In addition, be sure to contact the appropriate organization to determine filing fees and regulations that your state has for Private Placements. A source you can consult for such information is The National Directory of Addresses and Telephone Numbers, which you can find in most libraries at the reserve desk. It lists the telephone numbers for many state agencies.

A contact list for a few selected states follows here.

Arizona

Arizona Corporation Commission $1300 \mathrm{~W}$. Washington

Phoenix, AZ 85007

(602) $542-4242$

California

Department of Corporation 3700 Wilshire Blvd., 6th Floor

Los Angeles, CA 90010

(213) 736-3015

Colorado

Colorado Division of Securities

1580 Lincoln, Suite 420

Denver, Colorado 80203

(303) 894-2320

\section{Massachusetts}

Massachusetts Securities Division

Room 1701

One Ashburton Place

Boston, MA 02108

Ohio

Ohio Division of Securities

77 S. High St., 22nd Floor

Columbus, OH 43266-0548

(614) 644-7381
"Technology-driven companies, especially start-ups need more capital at a much faster rate than their low-tech counterparts. The reason is straightforward.... they have a narrow window of opportunity in an environment that sees new technologies daily." Technology \& Jobs Agenda http:/ / www.ilcoaliation.org/ sec 1.htm

\section{Initial Public Offerings}

When a firm conducts an Initial Public Offering (IPO) or Goes Public, the life of that firm will never be the same. From that day forward, the company will have many owners, all of whom need information about every aspect of the business and all of whom will have a say in the future of the company. Management teams that are unwilling to share control of their business-as well as its risks and rewards-are not good candidates for an IPO. On the other hand, the rewards of going public are many. It is a means for recapitalizing a firm, and for appreciating a company's stock value. Going public brings prestige and glamour to a company. It is a good strategy to use if positioning for an acquisition or a merger. It is also the primary vehicle used by the venture capital community for "cashing out." The downside, as mentioned previously, includes loss of control, strict disclosure requirements, and costof both initiating the IPO and operating as a public company afterwards. 
The costs associated with IPOs fall into four categories:

- Underwriter costs

- Professional costs

- Up-front costs

- Hidden and future costs

An underwriter is an investment banker or a broker/dealer who serves as an intermediary between a) the company offering securities for sale, and b) the investing public that purchases them. The underwriter's fee, sometimes referred to as a commission or underwriter's discount, is a percentage of the value of the stock sold. For smaller offerings, the current standard is approximately $10 \%$. In addition, the underwriter receives an expense allowance ranging from 1 to $4 \%$ of the amounts raised in the IPO. Thus, if your IPO were for $\$ 10$ million, the underwriter's discount at $10 \%$ would be $\$ 1$ million. The expense allowance of the IPO, say $2 \%$, would be an additional $\$ 200,000$. So in this case, the total underwriter's cost would be $\$ 1.2$ million.

A few additional notes on IPO fees and documentation:

Professional fees include the cost of attorneys and accountants, and can vary widely-between $\$ 20,000$ and $\$ 200,000$, depending on the size of the issue. Professional expenses are in large part determined by the amount of corporate cleanup resulting from previous arrangements, poor record-keeping and related complexities.

Up-front fees include costs for printing the Registration statement, the document referred to as a red herring, and the definitive prospectus. The total printing costs can vary between $\$ 10,000$ and $\$ 40,000$. There are also filing fees with the SEC, the state, the National Association of Securities Dealers, and other entities. Many of these fees are expressed as a percentage of the total amount of the offering.

After the IPO, the company will have the continued obligation to prepare and print a variety of disclosure documents, including a Form SR: Application of Proceeds; Form 8-K: Current Reports; Form 10-K: Annual Report; Form 10-Q: Quarterly Report. As a result, a publicly traded company needs to add staff or contract with a financial public relations firm to produce such documentation throughout the life of the public company. The role of management also shifts, to assure that good relationships are maintained with the shareholders.

Arkebauer calculates that, for smaller offerings, total costs and expenses can reach $24 \%$ to $39 \%$ of the offering. Choosing a private placement rather than and IPO can obviate the need for many of these expenses, restrictions, and reporting requirements. 


\section{Tools to use with Equity Investors}

The following section contains a description of and the outlines for various tools that you will need to interest equity investors, or to assist in your negotiations with them.

\section{The Business Plan}

To be useful, a business plan must be very specific, for only in the presence of detailed information can one ascertain customer needs and develop strategies, costs, and realistic financial goals. This need for specificity means that you should limit the scope of your business plan, however. For example, suppose you have developed a rich technology platform that has diverse applications in the automotive, computer, and chemical industries. Furthermore, suppose you wish to pursue different commercialization strategies with each application-licensing to the automotive industry, equity financing to manufacture a component for use in the computer industry, and a joint venture with a large firm in the chemical industry. The question is whether you should develop one business plan or three. In order to make the business planning process productive and manageable, the answer is three: one plan around each of the three different applications. If you tried to tackle all three concurrently, the information would be kept at the macro level, resulting in a superficial, misleading treatment of the opportunities. Technology-rich companies are best served by developing plans around a) lines of business, b) strategic business units, or c) product lines aimed at similar markets.

Scope also refers to time. Business plans have a five-year horizon. In other words, they reflect a course charted for a five-year period. The operational plans for the first year are usually expressed in great detail, and in a more general fashion for years two through five. Business plans should be revisited annually (if not more frequently), and adjustments made in light of new information acquired during the realization of the first year's goals and objectives.

A business plan is the result of a rigorous planning process. As in science, the document produced is only as good as the research that precedes it. To merely package the information that you currently have without first testing your hypotheses and assumptions would be tantamount to writing a conclusive technical paper based on the hypotheses and assumptions that precede rigorous scientific inquiry. Detailed guidelines for conducting the business research which precedes the development of an excellent business plan can be found in Business Planning for Scientists and Engineers (Servo, 1999). Section 3 of this ATP guide includes activities to help the entrepreneur develop a more detailed picture of his or her business opportunity. 


\section{Commercialization Plans vs. Business Plans}

Companies often confuse business plans with commercialization plans. The two are not the same, even though they do have a direct bearing on one another. A commercialization plan is a strategic statement of how you will bring one or more technologies to market. It is a strategic overview that often includes an analysis of which applications and which markets are likely to mature first. By contrast, a business plan is detailed and charts a clear, specific path to realizing financial reward around well-defined opportunities. Each business plan will tie back to the commercialization plan. In summary, a commercialization plan is macro, the business plan is micro; a commercialization plan is global, a business plan is specific; and a commercialization plan encompasses a whole technology, while a business plan is tied to lines of business.

\section{The Prospectus vs. The Business Plan}

Confusion often arises between a business plan and a prospectus. A prospectus is a stylized, public, disclosure document developed in accordance with the guidelines of the Securities and Exchange Commission. It is developed specifically for an external audience of unqualified and qualified investors-investment bankers place much emphasis on this document. "Buyer beware" is the message that the prospectus must portray. The focus of the document is full disclosure of financials, money requested and how it will be used, risk, and the management team. The prospectus does not address the market, customers, or operational plans in the fashion described in the business plan. Nevertheless, a business plan is an important document for companies wishing to go public. It is a necessary document for gaining the interest and involvement of viable underwriters.

\section{Who Should Develop a Business Plan?}

The founder of a small company is often overextended, and often looks to others to draft a business plan for the company. When money is readily available, a founder usually hires a consultant. When funds are tight, however, a founder often tries to involve someone else in developing the plan "on-spec"-that is, to invest his/her time working on the plans in exchange for a job or an equity positions in the firm. If you are the founder, develop your business plan yourself-no matter how appealing these other options may seem. As the leader of your firm, you must be directly and intimately involved. Business planning is a transformational process, and if you are not involved, you will fail to grow with your business. If you are serious about developing a good business plan, you must begin by setting aside time on a weekly

This outline is to be used in the post-ATP-award period ONLY. Please consult ATP's proposal preparation guidelines if you are preparing a business plan to submit as part of an ATP proposal.

No matter how appealing it may be to have someone else develop a business plan for your company, you must do it yourself. 
basis to complete various tasks associated with the business planning process.

At the same time, being involved does not mean that you should proceed without help. Quite the contrary. In order to be able to add this activity to an already busy schedule, you must look for ways to leverage your time-by finding an appropriate way of involving others.

\section{What Format Do I Follow?}

We have included two versions of a business plan outline on the following pages to familiarize you with what the end product should look like. When reviewing these outlines, keep in mind that any business plan is only as good as the research that precedes it. If you merely package the hypotheses and assumptions that you currently have, you will have missed the point. Once again: a good business plan requires good business planning.

Why two business plan outlines? The first provides you with an overall look at the structure of the document. When used as a selling tool, the purpose of this general business plan is to create a logical case for investment. Section 2 of the plan states who you are and what you have. Sections 3 to 5 constitute the market assessment. The purpose of the market assessment is to demonstrate that you have firsthand experience with your customers and that there are enough of them who are ready, willing, and able to buy your product, technology, or service. Sections 7 to 10 indicate how your company will realize this opportunity, and consist of a set of operational plans for each functional area. Section 11, the contingencies section, indicates that you have thought through responses to various impediments that may arise, and that you recognize that any business is fallible. Section 12, the financials section, builds on everything that has gone before. Revenue streams are identified, and costs are clarified for each functional area. This section is a numerical presentation-the one that articulates how you will grow the company and provide a return on investment (ROI) for you and your investors.

The second plan outline provides the elements of a good business case in more detail. The items in italics are topics to be addressed in whatever sequence seems most appropriate. 


\section{BUSINESS PLAN OUTLINE (GENERAL)}

1. Executive Summary

2. Company \& Technology

3. Customers

4. Market

5. Industry Analysis

6. Competitors

7. Marketing/ Sales Plan

8. R\&D Plan

9. Manufacturing/ Engineering Plan

10. Human Resource Plan

11. Contingencies

12. Financials

13. Appendices

14. References 


\section{BUSINESS PLAN OUTLINE (DETAILED)}

Cover Page

Table of Contents

\section{EXECUTIVE SUMMARY}

2. COMPANY \& TECHNOLOGY

2.1 Brief company introduction

- Mission

- Location, size, history

- Overview of company capabilities

- Customers \& past performance

2.2 Product or technology description

- Brief description

- Present state of development

2.2.1 Intellectual property status

2.3 Commercialization strategy

\section{CUSTOMERS}

3.1 Customers $\&$ end-users

- Description and geographic distribution

- How need is currently filled

3.2 Buying behavior

- Decision makers

- Influencers

- Basis for purchase decisions

- Frequency of purchase decisions

\section{MARKET}

4.1. Market definition

4.1.1. Primary market

4.1.2. Secondary markets

4.2. Market size and trends - Primary market

- Current total and served-available markets

- Predicted annual growth rate 


\section{INDUSTRY ANALYSIS}

5.1. Industry definition and description

- Relevant SIC

- Current industry status

New products and developments within the industry

5.2. Legislation and policies driving the industry

- Future and historical trends

\section{COMPETITORS}

6.1. Indirect competitors

6.2. Direct competitors

- Who are they?

- Strengths and weaknesses

- Market share of competitors

\section{MARKETING/ SALES PLAN}

7.1. Marketing $\&$ sales objectives

7.2. Current customers (if appropriate)

7.3. Potential customers

- Customers targeted for intensive selling efforts

- How other customers will be identified and qualified

- Product features emphasized and contrasted with competitors

7.4. Analysis of potential teaming partners

- Who are they?

- Basis for selection: strengths, weaknesses, and synergies

7.5. Pricing

- Basis for targeted price point

- Margins \& levels of profitability at various levels of production and sales

7.6. Sales Plan

- Sales force analysis (reps, distributors, direct)

- Sales expectations for each salesperson and each distribution channel

- Margins given to intermediaries

- Service and warranties 
- Organizational chart for sales/ marketing staff, indicating planned growth for 3 - 5 years

7.7. Advertising

- Year 1: Detailed Marketing Communications plan

- Year 2 - 5 (general)

7.8. Sales/Marketing Budget*

- Assumptions

\section{8. $R \& D$ PLAN}

8.1. $R \& D$ Objectives

8.2. Milestones and current status

- What remains to be done to make the product marketable?

8.3. Difficulties and risks

8.4. Staffing

8.5. $R \& D$ Budget*

- Assumptions

9. MANUFACTURING/ ENGINEERING PLAN

9.1. Objectives

9.2. Use of Subcontractors

9.3. Quality control

9.4. Staffing

9.5. Manufacturing/ Engineering budget*

- Assumptions

10. HUMAN RESOURCE PLAN

10.1. Staffing Objectives

10.2. Organizational structure - over 3-5 years

- Introduction of management team

- Key individuals to be recruited and plans for recruiting

- Board of Directors, Advisory Board

- Incentives for commitment

10.3. Human Resource Budget*

- Assumptions 


\section{CONTINGENCIES}

11.1. Potential Risks

- Impact and responses

\section{FINANCIALS}

12.1. Financial Objectives

- Commercialization strategy

- Use of fund

- Terms \& conditions of any previous financing arrangements

12.2. Pro Forma Profit $\&$ Loss statements

12.3. Pro Forma Cash Flow projections

12.4. Pro Forma Balance Sheet

12.5. Alternative return scenarios

- Exit scenarios

\section{Appendices}

\section{References}

* In the initial draft of the business plan, include the budget for each functional area at the end of each section as indicated. In the final draft you may prefer to remove these individual budgets and weave them into the financials, in Section 12. 


\section{Executive Summary}

Investors often start by reading ONLY your executive summary and financialsthen they make a decision as to whether they should read the rest of the plan. Because the executive summary is so important, we include a suggested outline of one below. The summary should be no longer than three pages in length, and may include figures and tables.

\section{Company \& Background}

- company location and mission statement, sustainable competitive advantage

- background on core technology

- commercialization strategy

The Market Opportunity

D market need

D market size and trends

Management Team

D key players and relevant background

- highlights and accomplishments

Investment Highlights

D what level of financing you seek

- how funds will be used

D what type of partner/investor you seek

Dhy this is a good opportunity

\section{Get Feedback on the Plan}

Once you have your first draft of the plan, do NOT give it directly to a potential investor to read. It will be too long and cumbersome. Give it to others-including members of your team and board members for feedback. Tell them that you know it is too long, but that would like to know their reaction to the content-with specific attention to all of the action plans that you have mapped out for the company. Gather their feedback, and use it to re-evaluate your course of action. 
The next draft of the business plan should be the one you prepare for distribution. This is the point at which you must pay attention to page limits. The way to reduce the length of your plan is to use graphics, tables, and charts wherever you can and relegate some information to appendices. In this final iteration, form becomes vital. As you work on the final draft, you should keep in mind an old Marshall McLuhan cliche: "The medium is the message." In other words, you should remember that the appearance of the document, i.e., the form in which the business plan is presented, tells the potential investor something about you. Furthermore, it affects the attitude with which he or she will read your document. It determines whether your plan stands out among the hundreds of others the investor has to review. The messages you want to leave with the investor are that you: 1) have a technology that is of value; 2) are an excellent technologist; 3) are also a business person, and are sensitive to market issues, design, engineering, and production costs; 4) have an opportunity for him or her to consider; and 5) have a good firm with which to work.

Some general guidelines are listed below:

D Adopt a style that you will use throughout.

- Use a type font and point size that are easy to read.

Dhenever possible, represent market data by use of pie charts, tables, and other figures.

D Represent development time lines with Gantt and PERT charts.

D If you have too much data for some sections of the plan, place them in the Appendices. The document should read smoothly and not appear to go off on many tangents.

- Make sure the document photocopies well.

D Consider the use of color.

Due to their proprietary nature, we could not include in this Guide a copy of any of the business plans we have helped to develop. Nevertheless, we hope our guidelines will give you a sense of what is required. 


\section{Guidelines for Business Plan Revisions}

Listed below are some general guidelines regarding page lengths.
1. Executive summary
2 - 3 pages
2. Company \& Technology
3 pages
3. Customers
2 - 3 pages
4. Market
2 - 3 pages
5. Industry analysis
1 page
6. Competitors
2 - 3 pages
7. Marketing/sales plan
3 - 4 pages
8. R \& D plan
2 - 3 pages
9. Manufacturing/Engineering plan
2 - 3 pages
10. Human resource plan
2 - 3 pages
11. Contingencies
1 page
12. Financials
3 - 4 pages

Do not "overshop" your business plan. In other words, do NOT send it out to every venture capitalist in your geographic area. Be selective. Your opportunity should generate excitement and be something which only the appropriate audience sees.

\section{How to Use Your Business Plan}

Your business plan has both internal and external value. Since the external value is the primary purpose, we will discuss the external application first. Your business plan should be valid for approximately one year. (At the end of that period, you should reassess the situation and revise the plan as necessary.) During the course of the year, your business plan will serve as a very important selling document. You should distribute it with great care, however, as it contains very complete information on your business. Listed below are some general guidelines for distribution.

\section{Distribution protocols}

(1) Distribute your plan only to those who have demonstrated a sincere interest in your technology/product. Gauge their sincerity by the confidence and trust they engender.

(2) Keep track of all your business plan copies by number, recording their distribution in a log. Request their return within 30 days. Extend on an exception basis only.

(3) Clearly mark each business plan copy in the following manner: Proprietary, Confidential, Not to be Duplicated.

(4) Ask any person to whom you are considering giving the plan to sign a confidentiality agreement. If the individual has any problem doing so, you can remove the more sensitive sections of your plan. 


\section{How to Create Opportunities for Distributing Your Plan}

During the development of your plan, you will have taken several steps "to get close to the customer." This should be an ongoing activity. In the process, it is likely that you will find potential teaming partners. If you are particularly impressed with a potential customer, explore whether the customer has any interest in developing a relationship (research and development partnership, licensing, or other teaming arrangements). At this point, you are looking to create a sponsor. If there appears to be interest, ask the potential sponsor to sign a confidentiality agreement. Although some companies are reluctant, they do sign confidentiality agreements if the prospects look promising. Once the agreement has been signed, share your business plan with the company following the protocols outlined above.

If a potential sponsor is reluctant to sign a confidentiality agreement, you could provide him with an abbreviated copy of your Executive Summary to whet his appetite. Be sure that the summary provided on this basis contains no proprietary information. Once a confidentiality agreement has been signed, some companies provide only the abbreviated financials in the financials section of the plan, placing the complete set in an appendix.

\section{How Do You Know If You Are Making Progress?}

The following steps indicate increasing interest on the part of a potential sponsor:

(1) Potential sponsor signs a confidentiality agreement

(2) Site visits—needs are clarified

(3) "Due diligence"- the potential sponsor does some probing at his own expense, usually into the markets.

(4) Another site visit

(5) Negotiations begin

During this process, pay particularly close attention to the objections and concerns raised by the potential sponsor. Try to formulate ways in which these can be addressed, whether by research and development activities or by other means. The negotiations that ensue involve clarification and give-and-take by both parties. Stay in contact and be responsive. If the negotiations end with the investor saying, "Get back to me when you have addressed issue X," be sure to do so! This type of statement is typically a "buying signal." Your response should be, "If we can solve this problem, would you be interested in X?" Don't feel that because an objection was raised the door has been closed forever. Remember that the potential sponsor has already invested time and money in the evaluation of the opportunity. If you address the concerns and are persistent, you will present yourself as a responsive potential partner. 


\section{Internal Value of the Plan}

The biggest mistake a company can make is to put its business plan on the shelf once it has attempted to obtain funds. A well-developed business plan should act as your guide and as a rallying point for your staff. In quarterly reviews with your management team, see how the company is tracking relative to goals and objectives articulated in the plan. Use the business plan as a screen to decide whether unforeseen events are opportunities or diversions. Also use it to remind yourself of your priorities.

As conditions change-and as you continue to learn about your market and how your company is perceived-your plan will change. Just as a ship's captain adjusts course when the winds change direction, so will you. It is, therefore, important to re-work your plan annually. This re-working will seldom require as much work as the original draft, because you will have considerable data in hand, will understand the business planning process, and will know how to go about looking for opportunities.

\section{Summary}

Take great care in the drafting and distributing of your business plan. It should communicate effectively with the intended audience, whether internal or external. Keep the document alive. Use it to guide your behavior, benchmark your progress, effectively communicate with your management, and seek investors and strategic allies.

By the time you have created a solid business plan, it will contain a considerable amount of in-depth information about your firm and the business opportunity you seek to exploit. For this reason, it is best to pre-qualify potential partners and investors before sharing your plan with them. This pre-qualification can often be accomplished within the context of a non-proprietary oral presentation that highlights the salient aspects of the business case. The next chapter includes a sample presentation. 
PRE SEN TIN G

Y OUR

OP P ORTUNITIES

TO EQUITY

I N VESTORS
Company/ Technology/ Product

Market Assessments

Goals and Objectives

Challenges/ Requirements/ Opportunities 


\section{Advanced Organizer}

Most ATP-funded firms are positioning themselves to become high-potential ventures. Issues related to financing, developing joint ventures, and commercialization strategies were addressed in preparation for submitting an initial ATP proposal. Advanced technology firms often have a long-term appetite for capital, however, and must be diligent in their efforts to attract it. A diligent but reasoned approach to investment will increase the likelihood that private sector funds will be available when needed for your company's growth. The objective of this section is to provide guidance on a method for succinctly representing your opportunity in an oral presentation to private sector investors.

The section begins with a description of the typical contexts in which such presentations are made. These include: (1) presentations to groups at national and/or regional events; (2) presentations to local groups of business angels; and (3) presentations to potential partners/investors. This chapter deals ONLY with personal presentations and does not address other approaches to finding potential allies/investors, such as press releases, computerized matchmaking, or advertisements. Although these can be useful adjuncts to other initiatives, personal presentations provide both parties with the opportunity to assess the individuals involved and to begin the development of a relationship.

The remainder of the section consists of a fictitious presentation to potential equity investors. A set of viewgraphs, sample narrative, and explanatory notes are included. It is just an example, and can be modified to meet individual needs.

It is important for busy entrepreneurs to develop a procedure that will allow them to qualify potential partners/investors quickly and to diligently pursue promising ones while graciously closing the loop with others. 


\section{Opportunities for Making Personal Presentations}

\section{Presentations at National and/ or Regional Events}

Once you have developed your business plan, creating a set of presentation materials that you can use to bring your business opportunity to the attention of potential strategic allies and investors is invaluable. Although such presentations are often made within the context of individual meetings with qualified leads and referrals, national, regional, and local investment events provide an ideal context for making a presentation to numerous organizations concurrently. If it appears that historically a specific event has attracted the types of organizations that are of interest to your firm, it will be cost-effective to participate in that event. At the same time, you should exhibit restraint in making any public presentations when preparing for an Initial Public Offering and/or if you have signed a "stand-still" agreement. Legal restrictions apply in these situations.

\section{Calendar of Events}

Many investment events are promoted within industry trade journals. A sampler of annual events that might be appropriate for well-prepared entrepreneurs to attend is listed below. In some cases, geographic and/or topic restrictions apply. Most of these events involve a screening process to select viable participants based on a preliminary review of an executive summary and/or business plan. You should anticipate participation fees of between $\$ 200$ and $\$ 900$. Names of some of the more well known investor events are listed below:

- Arizona Venture Capital Forum

- Bio Investment and Partnering Conference

- Florida Venture Capital Conference

- The Great Midwest Venture Capital Conference

- Illinois Venture Capital Conference

- MidAtlantic Venture Fair

- North Coast Growth Capital Conference and Technology Showcase

- Pittsburgh Venture Capital Conference

- Software Investment Conference

- Upstate New York Venture Capital Forum

- Venture Market East 


\section{Presentations to Local Business Angels}

Many communities have groups of business angels and institutional investors which meet frequently to learn about new business opportunities. These events tend not to be well advertised. The best way to find out about them is to contact your local Chamber of Commerce. Inquire whether there is a local venture capital or investment group that meets regularly. Indicate that you are interested in presenting your business opportunity and would like to contact the person responsible for scheduling presenters. For example, if you were to contact the Rochester Chamber of Commerce, you would find that a Venture Capital Breakfast has been held there on a monthly basis for several years. There is room on the agenda for each of these breakfasts for three local businesses to present their business opportunities. The audience typically consists of 30-40 people, including service providers and potential investors. Most large communities have such groups.

Although larger events run by institutional investors tend to be much more effective than smaller, more local events, the value of participating in local investment events is that they provide a context for you to appear in front of the community's establishment. The contacts you make here may know people in larger financial communities, and may be able to assist you with networking.

\section{Individual Presentations During Site Visits}

A presentation made within the context of an investor or partnering event is the first step in developing a successful relationship. A desirable outcome is for a potential investor/partner to request a site visit.

Before your visitor arrives, be sure to determine the objectives of the visit and whether others will accompany him or her. It is important to understand both the roles and objectives of the visitors so that you can determine what information is important to share with them.

Information that you provide must be relevant to your visitors' goals. If the people making the site visit represent a corporate venturing area and have a strong background in marketing and sales, it would be inappropriate to spend a great deal of time talking about research and development. It would be far more important to talk about value creation and marketing and sales initiatives. Provide your visitor with materials that they can use to sell up-line. Decisions regarding partnering and/or investing are rarely made by one person. Others need to be convinced of the value your opportunity has for their organization. Therefore, always provide an 
appropriate packet of information that he or she can share on your behalf. If the visitor has not signed a confidentiality agreement, be certain that you share only non-proprietary information.

\section{Preparing a Winning Presentation}

If given in its entirety, a presentation addressing all the topics covered in this section could run between 30 minutes and an hour. For a shorter presentation, such as is typical for presentations to a group of potential investors, you will need to modify your viewgraphs based on the needs of your audience.
Irrespective of where you are making your presentation, you will find it invaluable to have a well-prepared set of slides or transparencies to draw upon. In this section, we provide guidance on how to prepare and deliver a presentation to investors. The following opportunity by Soarrell Medical Systems is fictitious. It is based upon issues and trends in information systems as they apply to health care.

This section includes topics and sample slides or transparencies designed to assist potential investors in quickly previewing the business opportunity of your company, product, or division. (The term viewgraph will be used throughout and will refer to either slides OR transparencies).

Keep in mind that you will want to vary your presentation depending upon your audience and your commercialization strategy. For example, if you are one of a diverse group of firms making a presentation to potential investors, your audience will need to pick up key concepts about diverse business opportunities quickly. Within an hour, your listener might hear a presentation on a new fiber optic material, a golf course, and a new medical cure. Your goal must be to focus the potential investor quickly on your opportunity, create a favorable impression, teach the listener key concepts, and provide financial information to serve as the basis for further discussions. In order to do this effectively, you must control the sequence of information and its manner of presentation.

The potential investors for whom this presentation is appropriate include venture capitalists, investment bankers, potential strategic partners, and upper management within your corporation.

If you are presenting your opportunity in a more homogeneous context, e.g., all of the presentations at the event relate to one focused area, you could spend less time "teaching" the audience about pertinent industry drivers and instead focus on the unique implications that your opportunity may have. This would avoid redundancy across presentations.

The presentation following outline can be used to reflect the business opportunity of an entire company or a strategic business unit within a larger firm. When deciding upon the scope of the business opportunities being presented, your goal should be clarity. Often, individuals in contract research and development

E Q U I T Y I N V E S TOR S (c) DAWNBREAKER PRESS, 1998 
firms try to represent the business opportunities spanning their entire company. This can be confusing. If your company is involved with highly diverse technologies, it may be best to focus on the opportunity related to a Strategic Business Unit (SBU).

Sample viewgraphs for each of 25 topics follow, accompanied by explanatory notes. The set of viewgraphs presents an opportunity for one fictitious firmSoarrell Medical Systems. If you wish to obtain a sense of the overall business case being made, scan the set of viewgraphs and the accompanying narrative first. Then, refer back to the accompanying notes associated with each viewgraph in order to understand why the presentation was developed in this fashion.

If you are unfamiliar with making business presentations, or if you wish to try a new approach, it is recommended that you try to emulate the set of viewgraphs presented. Once you have a "rough cut" of this set and are familiar with the approach, you can pick and choose and re-sequence the viewgraphs to meet the needs of different situations or personal preferences. The feedback we have received consistently from hundreds of investors over the last several years is that this format makes it very easy for them to form an initial impression of an opportunity. They can then start a one-on-one conversation at a higher level with companies in which they have an interest.

\section{Visuals}

The visuals that follow are grouped into four categories:

Company/Technology/Product; Market Assessment; Goals and Objectives; and Challenges/Requirements/Opportunities. Each viewgraph page contains explanatory notes with the following subheadings:

WHAT A clear description of the type of information to be included on this viewgraph

WHY An explanation as to why that information is important for the investor's decision-making process

PITFALLS TO AVOID Typical mistakes frequently made by technology entrepreneurs

VARIATIONS Variations on the theme to be expressed

VIEWGRAPH \# A sample viewgraph. Please note: Soarrell

Medical Systems is a fictitious company and the data provided

are fabricated. Do not use these data as a source of information. 
Some information in this section is taken from a proprietary document called Knock Their Socks Off: Making Winning Presentations to Investors, by Jenny C. Servo and Paul

D. Hauler.
NARRATIVE Accompanying script for the reader to see how the verbal presentation and the accompanying visuals work together.

HIGHLIGHTS Points that should be included in this section of your presentation.

The viewgraphs are intentionally brief. Remember: readers are not listeners! The goal is to capture the audience's full attention. The viewgraphs you ultimately produce must emphasize and support key points that will be discussed during your presentation. The viewgraphs should not duplicate all the information you plan to express verbally.

You should aim to represent key concepts visually in 25 words or less. The reason for imposing this limit is to provide a simple index for assuring that you do not present too much information visually. Remember, the more words added to the viewgraphs, the greater the probability that the audience will become readers, rather than listeners. You will lose momentum and, more importantly, lose the opportunity to move potential investors through the first decision gate. That gate opens communication with the audience after the presentation. Use a pie chart, a simple table, or a picture to express a concept, whenever appropriate. Images are much easier for most listeners to retain.

When reading this section, your goal should be to understand the nature of the presentation. Before actually making the presentation, assess the unique characteristics of the audience, the opportunity, and the time constraints presented. Modify the final presentation as appropriate, by removing or adding materials. Keep in mind that this outline is intended to serve as a guide, not as a straight jacket. The presentations developed will be variations on the theme provided. First master the theme-then, improvise, as appropriate, to connect with your audience. 
Viewgraph 1:

Title Viewgraph

Viewgraph 2:

Mission

Viewgraph 3:

Management Team

Viewgraph 4:

Technology/ Product

Viewgraph 5:

Product Feature, Advantages, and Benefits (FABs)

Viewgraph 6:

Success Ingredients 
- Who are you? What is the nature of your opportunity?

- What does your company do? What gives it a unique edge in the marketplace?

- Who are your management team? What are their strengths?

What technology/product/service are you selling? What are its key features?

Can you present a visual picture? 


\section{Viewgraph 1: Title}

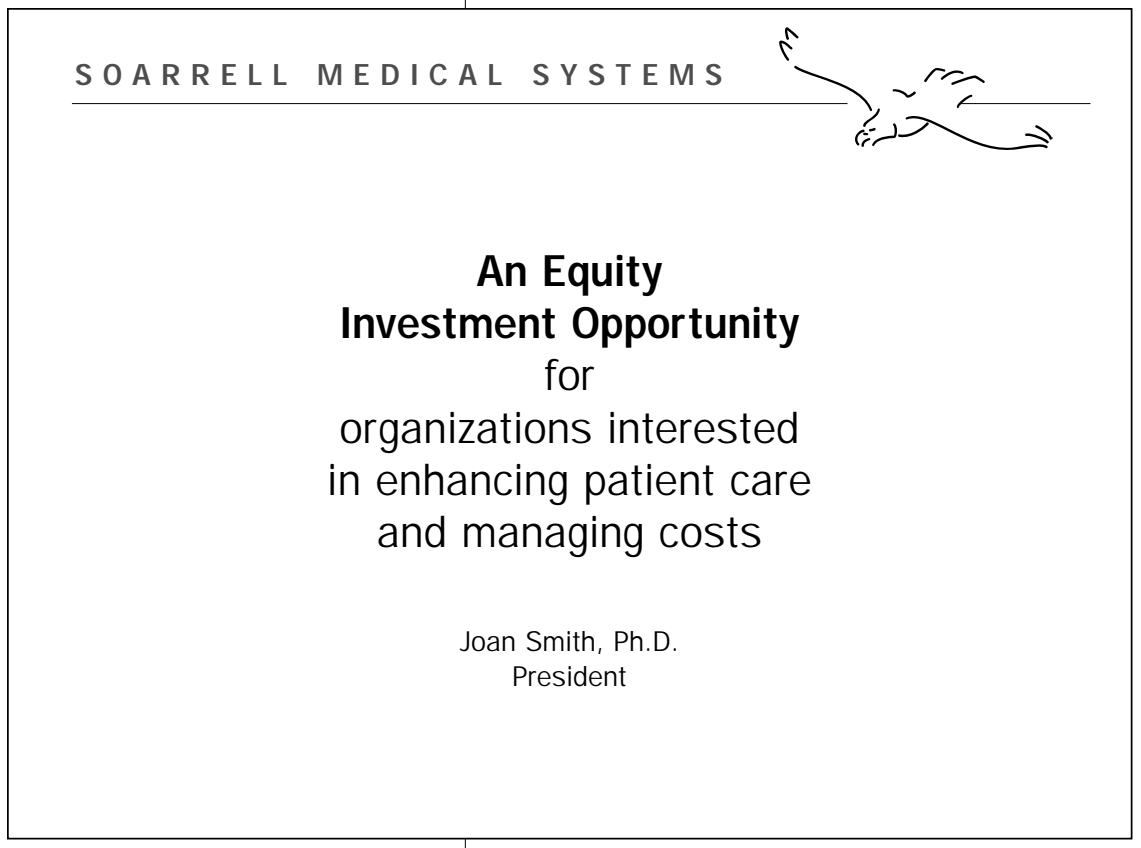

What

A title viewgraph simply presents who you are, the organization with which you are affiliated, and the nature of your opportunity. State on the title viewgraph whether this is an equity, joint venture, or licensing opportunity. Then provide a generic statement that describes the type of partner(s) or investor(s) in which you are interested. Unless you are able to easily produce slides or color transparencies, it is best that you not date the title slide or specify the event for which the viewgraphs have been prepared. That way, your viewgraphs will be reusable.

Why

When making a presentation at a partnering or investment event, there is often a flurry of activity among speakers as audience members enter and/or exit. A title slide gives the audience time to move about and re-orient. In this way, they will be focused when you begin to address substantive parts of your talk.

The title slide alerts the audience to the set of filters they should apply when listening to your opportunity. Depending on your commercialization strategy and how it relates to their interests, the audience will want to know more about specific parts of the presentation.

\section{Pitfalls to avoid}

Select a title that demonstrates that you know what is important to the audience, i.e., investment and/or partnering. If you select a title that only emphasizes the technology or the industry, it sends the message that your approach is academic, technical, and one-sided (what's in it for you). In this type of presentation, it is important to establish oneself as a businessman or woman, and to convey the opportunity as a benefit to those you wish to involve. 


\section{Narrative}

Good morning. I'm Dr. Smith, the President of Soarrell Medical Systems. In the next fere minutes, I will highlight those factors that make our opportunity worthy of your consideration. Soarrell Medical Systems is positioning itself to become a dominant player in the Computerized Patient Record market focusing on two niches: portability of patient records and patient education. We are seeking either a strategic alliance with a large HMO or an infusion of venture capital funds that will take us through initial product introduction. Long term, we are looking to be acquired by a larger supplier of practice management software.

\section{Highlights}

Notice that this presentation does NOT repeat information presented on the viewgraph. Instead, the narrative embellishes the key points in the visual presentation. The best presentations are those in which the speaker doesn't read from a text, but rather elaborates upon the viewgraphs in a predetermined fashion. The result is a presentation that looks impromptu, but is highly polished. 


\section{Viewgraph 2: Mission}

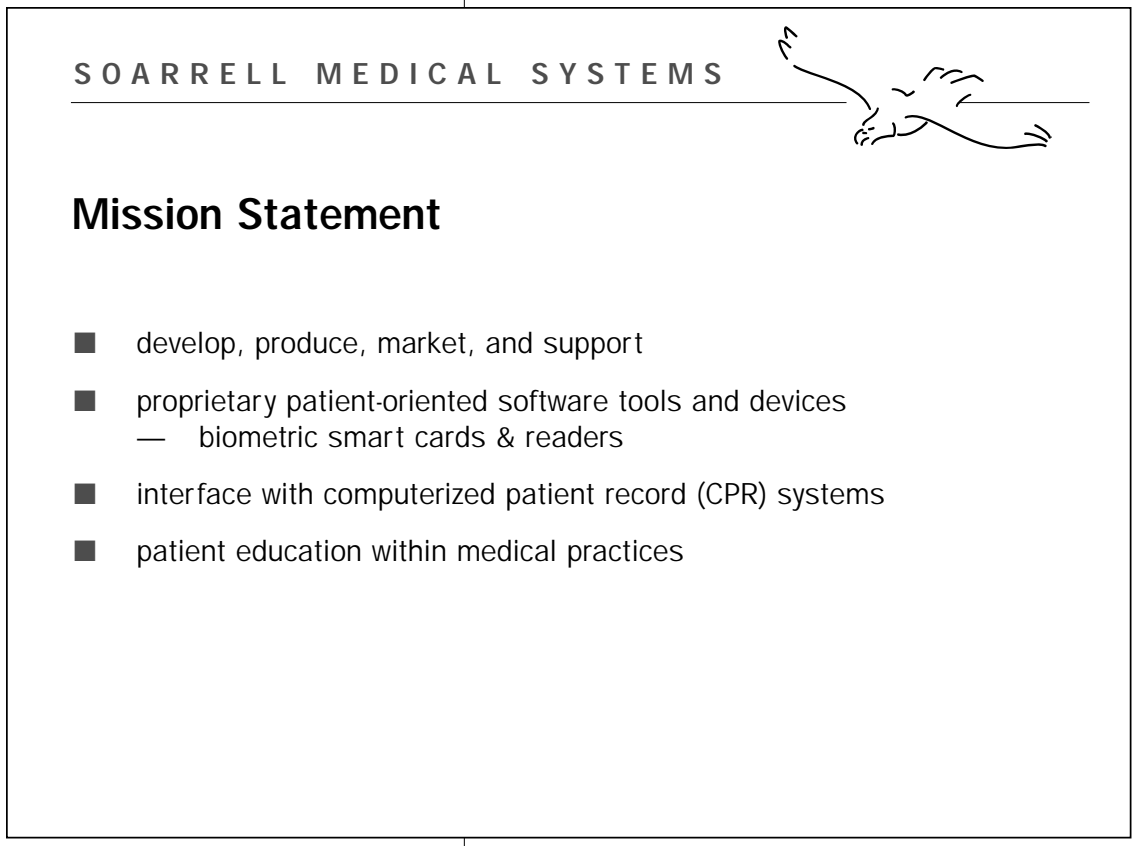

For assistance in developing your mission statement, see Workbook Activity 4. For assistance in articulating your sustainable competitive advantage, see Workbook Activity 2.

\section{What}

A mission statement is a clear, succinct statement describing:

D the business functions your company performs, i.e., research and development, marketing, manufacturing, distribution

- your company's sustainable competitive advantage

D the market or industry in which you operate

\section{Why}

In order to shape how the investor listens to your presentation, it is important to clarify at the outset what is most fundamental to your company-its mission. If you do not identify what your company does, the listener will spend time trying to ascertain this during the first few minutes and will miss other important information. Lead with the most fundamental information. Indicate which business functions your company or division performs: contract research and development, manufacturing, customer service, marketing and distribution. Clarify what is unique about your company and what will give your firm an edge in the marketplace, i.e., your sustainable competitive advantage. Also, name the market or industry in which you compete. Presenting this information at the outset provides the investor with a frame of reference and allows him or her to listen to your presentation intelligently. Also, be sure to mention the nature of your commercialization strategy.

\section{Pitfalls to Avoid}

Many times, entrepreneurs confuse "vision" with "mission." Although a vision statement is important, do not present it in this presentation. Vision statements tend to be "soft." Many new start-ups tend to focus on the creation of a culture in their vision statements, rather than emphasize business issues. The culture is of no interest to an investor, although it may be very important to you. If you talk about 
"vision," you are likely to get yourself into trouble, as the investor may attach unwanted stereotypes to you and your company.

Also, DO NOT make statements that would give the listener the impression that your mission is fragmented or unfocused. Statements like, "We are a contract research and development firm that performs cutting-edge research in any field" is a killer. What you have told the investor is that you chase research and development money and will do anything. Investors want to create value and not simply fund research and development.

\section{Narrative}

Soarrell Medical Systems develops unique software and hardware devices that interface with computerized patient record (CPR) systems. We are organized to provide excellent customer support. We also share the risk with clients and facilitate the shift to a new patient-practitioner relationship through training.

\section{Highlights}

Although the printed mission statement is somewhat dense and abbreviated, it clearly provides the potential investor with the appropriate frame of reference. The investor immediately knows what business functions Soarrell Medical Systems performs and what is unique about the firm. In the accompanying visuals, key words are clearly laid out and correspond with the unique features highlighted. Although the presenter does use some jargon (CPR), it is defined.

\section{Variations}

If you are presenting a business opportunity for a new strategic business unit, a spin-off business, or a division, it will be important to show your relationship to the parent organization and to clarify the mission of that organization. You might find that you need to add another graphic to show the relationship between this entity and others. Keep both the explanation and the graphics simple. 
Viewgraph 3: Management Team

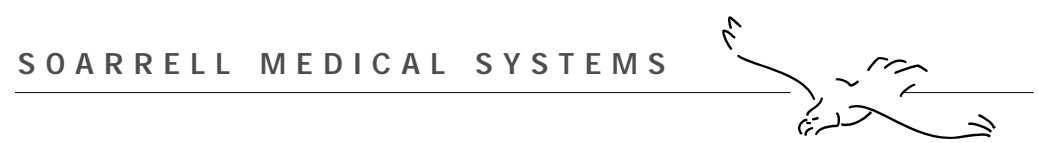

Management Team

Dr. Joan Smith-President

- Led 2 successful start-ups in medical industry

- Dr. Reginald Bolton-Vice President, Tech Transfer

- Skilled Practitioner, advocate of CPR, Inventor

- Mr. Trevor Baker-Vice President, Finance $\&$ Admission

- Twenty years' experience in medical business administration

\section{What}

Investors prefer management teams to individual proprietors for company management, as the latter are usually more vulnerable and less well-rounded. In this viewgraph, mention facts related to:

D management experience

- intellectual property developed by members of your team

D experience in your chosen marketplace

D other unique characteristics of your team that are relevant to investors

Why

Investors look for Grade A management teams, so it is important that you promote yourself. This is accomplished by making statements that will engender confidence in the ability of your management team to implement the business opportunity you are presenting. Establish credibility at the outset! Highlight the strengths of your team and their knowledge of the marketplace. Mention any unique intellectual property your firm may possess.

\section{Pitfalls to Avoid}

Although scientists and engineers have a natural tendency to highlight certain things that are significant to them-including the number of articles they have published, or the number of papers they have presented at international conferencesDO NOT feature this type of information. It reinforces in the investor's mind the stereotype of the scientist who is interested in obtaining funds for research and development, but who isn't really interested in creating value. While some readers may find this counter-intuitive, the point cannot be overstated. 


\section{Variations}

If, prior to receiving your ATP award, you primarily performed contract research and development, highlight the unique scientific credentials of primary players in your company. Combine this information with statements regarding successful performance on contracts, successful commercialization through licensing, and patent protection acquired. Such information will demonstrate to potential strategic alliance partners that you are experienced in these areas and will engender more confidence regarding teaming arrangements.

If your company is small and lacks a diversified management team, draw attention to the members of your Board of Directors, Advisory Board, or consultants and staff. Experience provides investors with confidence! If you do not have it, actively try to recruit such people to your company prior to making your presentation to investors.

\section{Narrative}

Soarrell Medical Systems is based in Boulder City, CO. Two members of our management team-Dr. Joan Smith and Dr. Reginald Bolton - have been with the firm since its formation in 1996. Mr. Baker was explicitly recruited to our management team earlier this year.

Dr. Bolton, Vice President of Tech Transfer, currently chairs a national CPR specification committee, practiced family medicine for 10 years, is the inventor of Soarrell's portable patient verification card, and is responsible for developing our training packages.

Mr. Trevor Baker is the most recent addition to the team and comes to us from the Alliant Health Systems Network. He has 20 years of hospital administration experience. In the CPR arena, he has a particular interest in patient confidentiality.

I'm Dr. Joan Smith, the President and founder of Soarrell Medical Systems. This is my third start-up company. In 1988, I started a software development firm that was acquired by Microsoft in 1993. In 1994, I was brought in as the CEO of a 5-year-old firm which specialized in archiving information for records management. Between 1994 and 1996, I led that company in a new direction which resulted in a 200\% increase in sales. In 1996, I founded Soarrell Medical Systems with Dr. Bolton.

\section{Highlights}

It is important to mention the location of your firm, because many investors limit their investments to firms that are within a two-hour distance from their office. Small start-ups are risky by their nature; you should highlight the amount of time your company has been in existence as appropriate. Mention those features of your management team's experience that will contribute favorably to investor confidence. 


\section{Viewgraph 4: Technology/ Product/ Service}

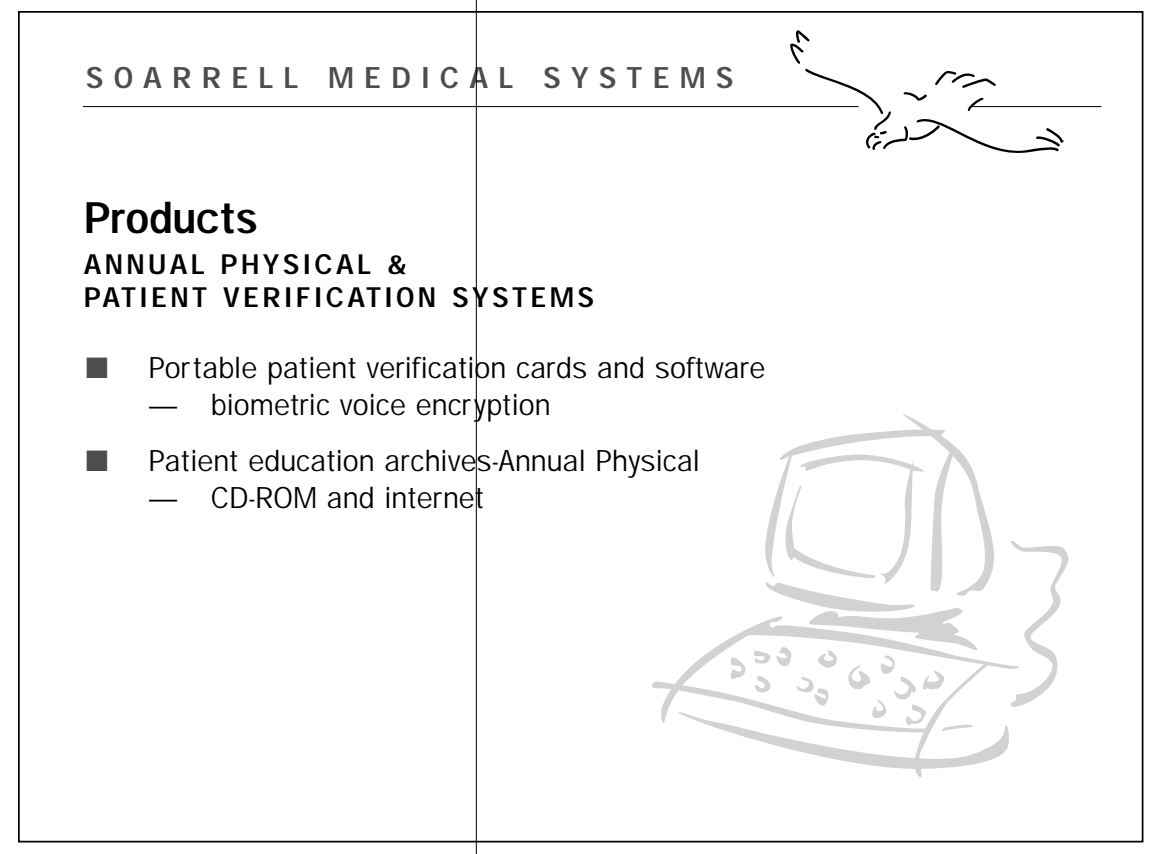

What

Once you have made your mission clear to investors (Viewgraph 2), and have given them a reason to listen to you (Viewgraph 3), you are ready to tell them about your technology, product, and/or service. Include a graphic representation of your product at this point. If your product is small in size, or if you have a small-scale model of the larger item, it is better to display the real thing. Nothing makes an impact like holding up a sample of the product. Depending upon your product's complexity, a series of viewgraphs may be valuable at this point. Without being overly complex, you need to convey to the listener what you have, before you move on to the next topic.

Why

For the most part, investors are looking to reduce risk. The more tangible the product or service, the less risk likely is associated with the project. Many investors are only interested in companies that are already selling products, as this shows market acceptance. If you are selling the product, make sure that it is abundantly clear in your accompanying dialogue.

\section{Pitfalls to Avoid}

The most common mistake made by scientists at this point in their presentation is to include either too much or too little information. Those who include too little tend to err on the side of paranoia. Those who include too much information do so because this area is their comfort zone. Whatever you do, DON'T fail to include a visual of your product. The worst presentations we have seen are those which have no visual aid regarding the technology, product, or service. Remember: the investor has to learn quickly about your company. If you fail to provide enough information, 
he will make an assumption (which may be faulty) about the product, or become distracted by trying to figure it out. Do not try to include a video in your presentation: switching mediums often results in fumbling and loss of momentum.

\section{Variations}

If your company has a family of related products, present a schematic that demonstrates what is common to the product family. The unifying factor may be a proprietary component that is used in a variety of products, or a technology base which is applied in different areas. Strive to demonstrate what it is that unifies your products or services; otherwise your opportunity may appear fragmented. Fragmentation presents a bad image to investors. They appreciate focus.

\section{Narrative}

Our initial product entry is a package that contains two items: a patient smart card and a computer archive with both internet and CD-ROM access. This package is called the "Annual Physical and Patient Verification System." The Portable Patient Verification Card ${ }^{I M}$ was designed by Dr. Bolton and uses a combination of known technology and patented biometric voice encryption algorithms. As you can see, this card looks like an ordinary credit card. This smart card has the patient's picture, name, and address on the front. Embedded in the card is an integrated circuit that contains pertinent information regarding the individual's immunization status, chronic problems, drug allergies, relevant family medical history, medical insurance status, and the like. Smart cards have read-write capability. Our unique biometric voice encryption algorithm assures that information on the card is activated and verified only by the patient, and that this is done on an annual basis. Health smart cards will be of great value to patients. Instead of a medical alert card, the individual will carry the patient smart card in his wallet. In case of an emergency, the card can quickly be scanned by ambulance or emergency personnel, or by modified home security systems of bedridden patients.

We have piloted the use of this card in a number of medical practices that are currently using computerized patient record software. It is used within the context of the Annual Physical Exam episode. Prior to the physical exam, a member of the clinician's staff reviews the relevant information that is contained within the CPR system with the patient, allowing the patient time to note any errors. This procedure is much akin to the process used at a bank for verifying on-line information regarding one's bank account. Once verified, a photo is taken and the patient is issued the Portable Patient Verification Card. Every year, prior to the physical exam, the information on file is reviewed for accuracy. It also is updated, and a new card issued.

The other component of this "Annual Physical and Patient Verification System" is an archive containing information regarding the most common ailments detected during a physical exam. The archive is stored in local libraries (CD-ROM) andlor on a server for the 
doctor's home page. Printed copies are also available from the vendor upon request.

When the result of the annual physical is mailed to a patient, the postcard lists both a URL and the library locations that have the CD-ROM. If the patient has internet access, he can look up relevant information from the remotely accessible server. If internet service is not available, he can review materials in the library or request that a copy be mailed to them. Following a review of relevant information regarding ailments, the patient would either call or E-mail the doctor's office to schedule a face-to-face meeting to discuss his questions and the recommended course of action. In subsequent years, scheduling of appointments could be handled electronically or by phone depending upon the individual's preference.

\section{Highlights}

You will notice that the presenter did not provide much information on the technical aspects of the product. The focus was on what the system does. Visuals were used to provide "face validity," i.e., to demonstrate that a real product exists. If your audience consists mostly of research and development personnel, it will be appropriate to spend more time elaborating upon unique features of the system.

However, avoid sharing any proprietary information during a public presentation. 
THIS PAGE HAS BEEN INTENTIALLY LEFT BLANK 


\section{Viewgraph 5: Product FABs}

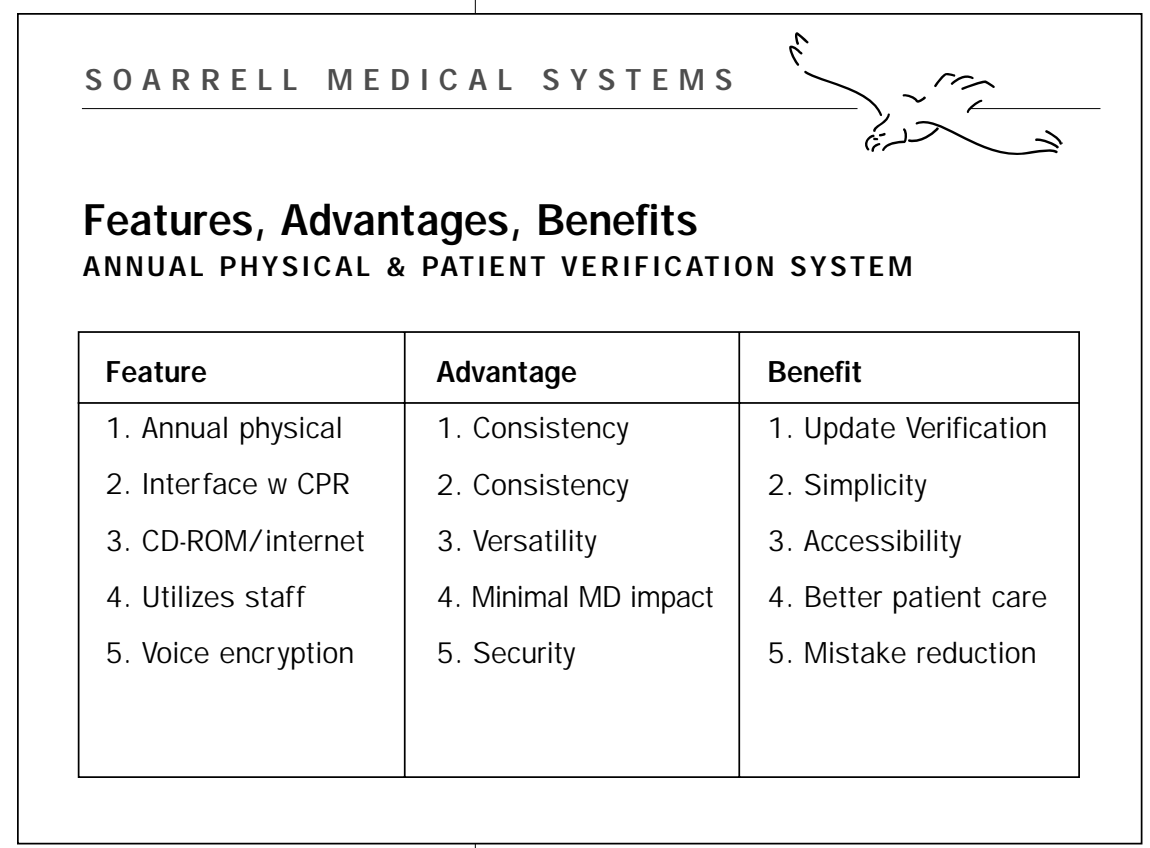

\section{What}

The acronym FAB stands for Feature, Advantage, and Benefit. A Feature is an element or property of the product or technology. The Advantage answers the question "so what?" and indicates the value of this feature. A Benefit describes the value to the customer or end user, as he or she would perceive it. Frequently FABs are best expressed in tabular form, often contrasting the product or technology with those of your competitors.

\section{Why}

First and foremost, the articulation of

For assistance in developing FABs, see Workbook Activity 7.
FABs assures that you are moving away from a subjective view of the technology to a perspective that focuses on the customer's needs. In developing these FABs, talk with both customers and end users to assure that the features of your product, technology, or service do indeed have an expressed benefit to them. The terms "customer" and "end-user" are NOT synonyms. "Customer" is defined as the person or organization that will purchase something directly from you. The "end-user" is the person that will ultimately use the product. The "end user" may or may not also be your customer. For example, suppose you wish to license computerized patient record software to a hospital. Your licensee will be your customer. The enduser is the person who ultimately uses the software, perhaps the office staff person who enters patient information. Understand the needs of both your customers and the end-users, as defined above.

Talking about FABs in your presentation makes it easier for the potential investor to see what is distinctive about the product and demonstrates that you are "getting close to the customer." 


\section{Pitfalls to Avoid}

Don't skimp on this part of the presentation. Develop FAB tables only after speaking with potential customers and end-users. Don't assume that you know what the customers want without speaking to them.

\section{Variations}

Sometimes this section will take the form of talking about competing technologies or different ways of addressing the problem you are solving. In this case, you would highlight the features, advantages, and benefits of your technology as compared with others. In such instances, you may need to use more than one viewgraph. Don't make your visuals too complex. The listener must be able to clearly ascertain your message. Remember the "KISS" acronym: Keep It Simple, Stupid! Just as complex theories indicate that it's time for something more simple and elegant, so it is with graphics. If a visual requires too much explanation, it's too complex.

Change it!

\section{Narrative}

There are several unique aspects of this system which make it extremely easy for a physician to add to an existing office management software suite. The Soarrell software used in producing the smart cards interfaces easily with the most commonly used CPR systems, including M.D. Workbench, SMART-MED, MedTrac, and SOAPware. The software can be used with any $P G$, with Mac G3's, and with Unix systems. Another feature of this system with great appeal to MDs is that it makes better use of para-professionals in the office and helps limit the MD's involvement to patient care.

\section{Highlights}

Note that the presenter did not go over every item listed in the viewgraph, but instead elaborated upon only a couple of items. This approach makes the presentation more interesting. The other information is there for the audience to read quickly or note. 


\section{Viewgraph 6: Success Ingredients}

SOARRELL MEDICAL SYSTEM S

r.

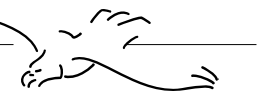

Success Ingredients

- Incentive payments based on patient satisfaction

- Computer platforms and CPR software supported

- Board of Advisors

- Intellectual property

- Physician in primary care role

\section{What}

In this viewgraph, tell the audience why your company will succeed. Statements must be comparative in nature, but need not necessarily single out specific competitors by name. For example, you can indicate a cost savings of $40 \%$ without naming the competitors. Delay specifics until later in this presentation to focus the listener's attention on the one item you wish to emphasize at this point: ingredients for your success.

\section{Why}

An investor or strategic partner is looking

to create value. This can be accomplished if you have products, technologies, or services which are unique (such as patent-protected products), and/or which are price or performance competitive. Success ingredients can also refer to items such as management team experience, established distribution networks, and the like.

\section{Pitfalls to Avoid}

Many scientists are accustomed to being cautionary in their statements and to qualifying everything they say. If you listen closely, you will hear scientists use qualifiers such as "may," "should," and "it seems." This use of qualifiers is often accompanied by the tendency to mention all the things that could go wrong and to be very guarded about conclusions. It is inappropriate to color the comments with such statements. Know what makes your company distinctively positioned for success. If you don't, you are not ready to make this presentation. Clearly, and without hesitation, state the advantage of your firm with respect to success. Later, address issues and contingencies for dealing with them. Don't be tentative in business. You must be knowledgeable, focused, and bold. 


\section{Variations}

The nature of your success ingredients is related to your company's mission, your management team, and your FABs. The items chosen as ingredients for success will vary from company to company.

\section{Narrative}

Soarrell's management team has the requisite experience for making this opportunity a significant financial success. As was indicated previously, the team has led start-ups before and our knowledge is deep with respect to the health care industry. In addition, Soarrell has proprietary technology that is perfectly positioned to become available at the right time. We are not too early or too late for this market opportunity. Our system is versatile and not limited by computer platforms or choice of CPR software. More importantly, we are willing to share a risk with our customers and to accept milestone fees based upon minimum disruption to the office workflow and increased patient satisfaction.

\section{Highlights}

In this example, the presenter used the opportunity to reemphasize the experience of the management team, as well as some of the FABs mentioned previously (i.e. versatility of platforms and software). Sharing the risk with the customer was a new concept that was introduced. 
Viewgraph 7:

Business Environment

Viewgraph 8:

Customer

Viewgraph 9:

Market Segmentation

Viewgraph 10:

Total and Served Available Market

Viewgraph 11:

Market Trends

Viewgraph 12:

Competition 
What is the market need you are addressing?

- Who are your customers? Who are your end-users?

- What market segment are you pursuing?

What is the size of this market segment?

What are the market trends for this segment?

- Who are your competition? What are they doing? 


\section{Viewgraph 7: Business Environment}

SOARRELL MEDICAL SYSTEM S

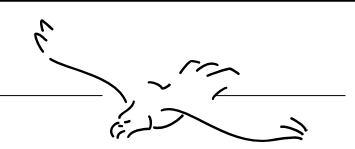

Business Environment

Slower move to CPR than expected

- Decentralization

- Growing apprehension about cost of hardware

- Lack of programmers

- Acquisitions

- Flattening of savings by HMOS

\section{What}

Now that your audience knows about your company's mission, management team, product, and ingredients for success, you will begin transitioning to discussions regarding the market. Do this in a staged fashion, describing the target market from a distant aerial view first, and then moving closer to the defined target. Carrying this analogy a little further, the business environment is the aerial view. It is the big picture that affects not only your market, but others as well.

The business environment statement should make reference, where appropriate, to things such as:

- Economic drivers

D Technology innovations

- Regulatory drivers

- Federal legislation and Executive Orders that will effect your market

- Federal, state, and local incentives, such as rebate programs

D Movements such as the quality control movement

D Changes in tax law

Keep in mind that these are sweeping movements which affect not only your market, but other industries as well. For example, the Patient Access to Responsible Care Act has an impact on the following industries: Heath-care delivery, Information Systems, and Legal. (This list is illustrative, not comprehensive.) Only mention those items that affect your market. For example, in the viewgraph provided, only Federal, state, and local policies are mentioned, since these have the greatest single impact on this opportunity. 
Why

What you are selling is only half the equation for commercial success. What people are buying is the other essential half. Examining your market from different vantagepoints increases the likelihood that you will understand those factors that affect your ability to compete. Such examination also helps determine if there is an existing market for your product and/or when one should emerge. Starting at this most distant perspective helps you to understand the more generic needs of potential customers. Aim selling efforts at matching your products with your customers' "needs." Keep in mind that "selling" is also involved when you are licensing. In the case of a license, you are selling to a potential licensee and must understand the market for the product into which the licensee will sell.

\section{Variations}

Depending on the factors at play in your business environment, you may wish to relabel this viewgraph "Federal, State, and Local Policies" or "Environmental Analysis." Also, in some presentations it makes more sense to mention the business environment before mentioning your opportunity. This may be the case if you are pursuing a licensing strategy.

\section{Narrative}

The major driver affecting the market for Soarrell's products is the need for cost containment of health-care delivery systems. In a report by Decision Resources, it was noted that in 1990, $25 \%$ of health care costs were administrative and most were associated with the management of patient information. As a response, information technologists focused on a bevy of issues associated with computerized patient records (CPR). In 1995, the Medical Records Institute went so far as to predict that the medical industry would spend up to $\$ 5$ trillion on computerized patient record systems between 1995 and the year 2000.

This has not happened. Problems plaguing the adoption of such systems include cost of hardware and software, lack of trained IT specialists, the Year 2000 problem, issues of client confidentiality, lack of standardized definitions of medical terms, and the fact that MDs would rather use software in running their business than in delivering their service.

Nonetheless, headway is being made, but at a slow pace and with twists and turns. There is a trend toward decentralized rather than centralized record keeping, with much headway being made in practitioners' offices. It has become increasingly recognized that informed patients are less expensive patients; i.e., they require fewer post-op doctor visits, develop greater trust of doctors, and have higher satisfaction and shorter recovery time.

For the most part, the general public is unaware of the changes taking place at the information technology level. Once the public becomes aware, it is likely that they will also become concerned about the type of information in the system, the correctness of the information, and how it will be used. The Annual Physical and Patient Verification System addresses this need. 


\section{Viewgraph 8: Customers}

SOARRELL MEDICAL SYSTEMS

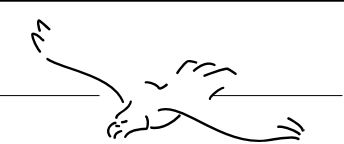

\section{Customers}

Medical practices already utilizing CPR

- Piloted program in Salt Lake City

- 200 patients in 5 practices

- increased customer satisfaction

- highly rated for ease of use by clinical staff
What

Before discussing the size of specific markets, identify who the customers are for your technology, product, and/or service. Be very clear about the definition of "customer." Remember that the customer is the entity that purchases products directly from you. Your firm might have more than one type of customer. For example, you may wish to license to some customers, but sell components that you manufacture directly to others. If you have a variety of customers, indicate this. Highlight the factors that affect your customers' buying decisions, as well as information regarding sell cycle, key product features, and your sustainable competitive advantage.

\section{Why}

Fundamental to commercial success is knowledge of your potential customers. Demonstrate to potential investors that you have clearly identified your customers and have spoken to them regarding the FABs (mentioned earlier). Remember, the investor and/or strategic ally is interested in creating wealth. This can only be accomplished if you have customers and if you have an intimate and documented knowledge of their needs. 


\section{Pitfalls to Avoid}

If you haven't met personally with potential customers, you are not ready to make this presentation.

\section{Variations}

If you are planning to license, break this discussion of customers into two sections-one about customers, and the other about end-users. Keep in mind that customers are entities that pay your firm, while end-users are the individuals or companies that actually use the product. Many times the end-users are not the individuals who purchase your product. For example, the end-users for a CAT Scan are highly skilled technicians in hospitals. However, they are usually not the individuals responsible for making the purchasing decisions regarding the CAT equipment.

\section{Narrative}

We will be focusing our initial marketing efforts on medical practices that already utiliwe a CPR system. We have just completed a beta test of our system in five medical practices in the Salt Lake City area. Our goal in this beta test was to determine ease of use for the various levels of staff in the medical practice and the patients' degree of satisfaction. There was minimal disruption of workflow in the medical practices during set-up.

Patients were surprised to know that the medical practitioners had computerized patient records and were pleased with the opportunity to verify their information. Errors were found in five percent of the cases. Twenty percent of the patients had internet access, and subsequent to receiving the results of their physical, downloaded relevant information from the practitioners' servers. Forty percent of the patients requested printed copies of reading material which we supplied; others asked to purchase a copy of the CD-ROM rather than using it in a library. Based on this input, we are considering making a copy of the medical archive directly available to patients at a reasonable charge.

\section{Highlights}

The presenter used this opportunity to clarify that there had been initial market acceptance of the system during a beta tet. The presenter further used the results of the beta test to indicate that there had been a change in strategy based on customer feedback.
For assistance in developing this section of your presentation see Workbook Activity 8. 


\section{Viewgraph 9: Market Segmentation}

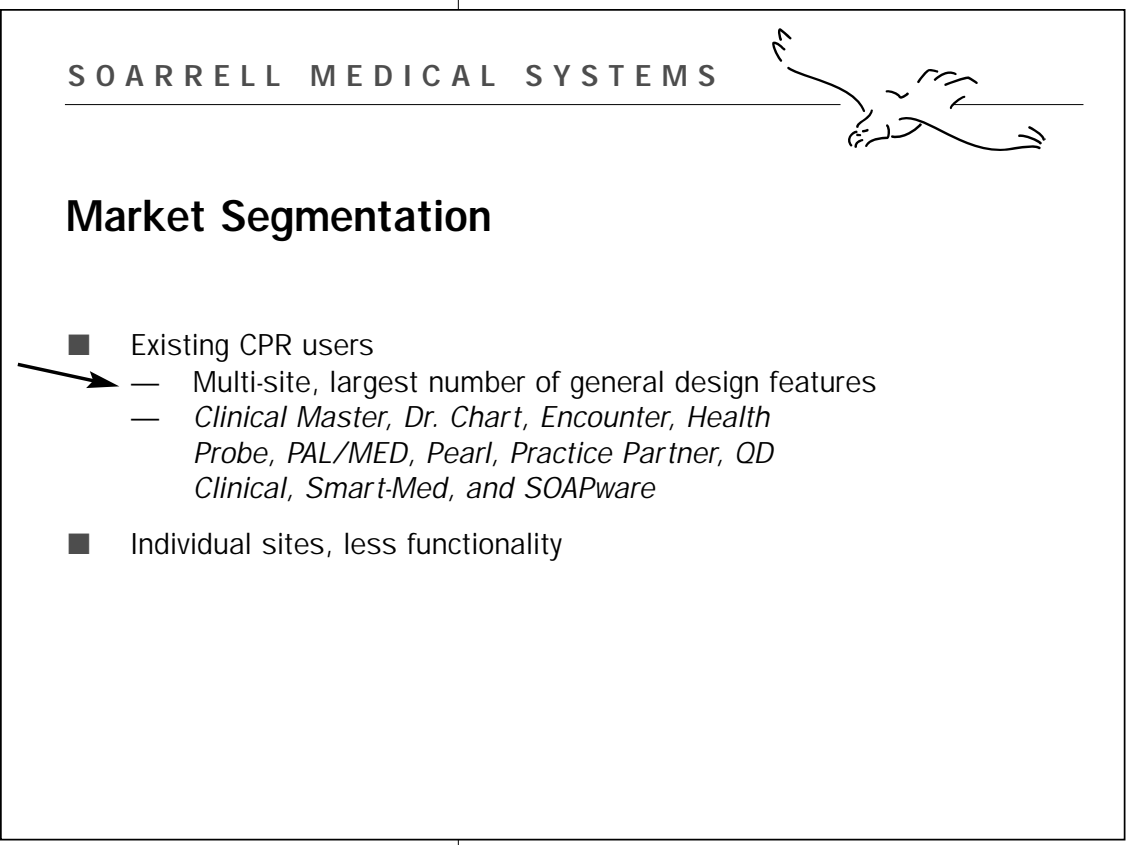

What

"Segmenting your market" refers to the process of grouping potential customers together in meaningful ways. The reason for grouping is to assess how large and how accessible the potential customer base is.

Determine whether the customer base can be reached through affordable advertising programs and whether this cluster or segment is large enough to sustain your business. If it is not, go back to the drawing board and try segmenting your market in different ways.

Segmenting the market appropriately is an art and takes considerable time and effort. When the market for your product, technology, or service is emerging, segmenting it is especially difficult. Some of the most common ways are by:

- Standard Industrial Classification Code (SIC) and/or North American Industrial Classification Codes (NAICS)

- Technology

D Product characteristics—high, medium, or low-end

Again, this list is illustrative and not exhaustive.

Why

The reason for segmenting your market is to make it more approachable and less amorphous. That is part of the process of carving out the domain for your business. 


\section{Pitfalls to Avoid}

A common mistake, and one that most first time entrepreneurs make, is to segment the market in such a way that it appears "really big!" Individuals who seek venture capital funds are most likely to make this mistake. They have often heard that the venture capital community won't be interested in an opportunity unless the market is substantial. Such entrepreneurs feel more comfortable saying that market $\mathrm{Y}$ is a $\$ 2$ billion industry and we will get $1 \%$ of that, rather than saying that market $\mathrm{Y} 1$ is a $\$ 50$ million market and our goal is to obtain $20 \%$ of that. The entrepreneur naively assumes that the investor would rather see a poorly defined $\$ 2$ billion market than a more tightly defined $\$ 50$ million market that is still within the range of investment interest. The reason for this error is the conceptual leap that only $1 \%$ of a huge market should be easy to attain, whereas stating a goal of $20 \%$ of $\$ 50$ million implies, "Oh my! We have to get real specific about how we are going to DO this." Yes, you do!

You should aim at defining your market in such a way that it's small enough for you to dominate and large enough to be profitable. Forty percent is better than one percent. The size of the market is obviously also important. Some markets are clearly too small to pursue.

\section{Narrative}

The computerized patient record market is rapidly emerging. Given that our software, smart card, and reader all interface with CPR systems, we decided that the best way to segment our potential market is to base it on the existing pool of medical practice CPR users. A number of surveys have been conducted by vendors of CPR systems, with the most recent being a survey completed in December 1997. The major vendors, the products, prices, and installed bases were described in that study.

\section{Highlights}

The presenter has provided a clear conceptual definition of the market that it will pursue, i.e., the installed base of CPR systems—focusing on those serving multiple sites and those with the greatest number of design features. Selected software programs with which it can interface are listed.
For assistance in developing this section of your presentation, see the Workbook Activities (7, 8 , and 9) under Customers/ EndUsers and Market 


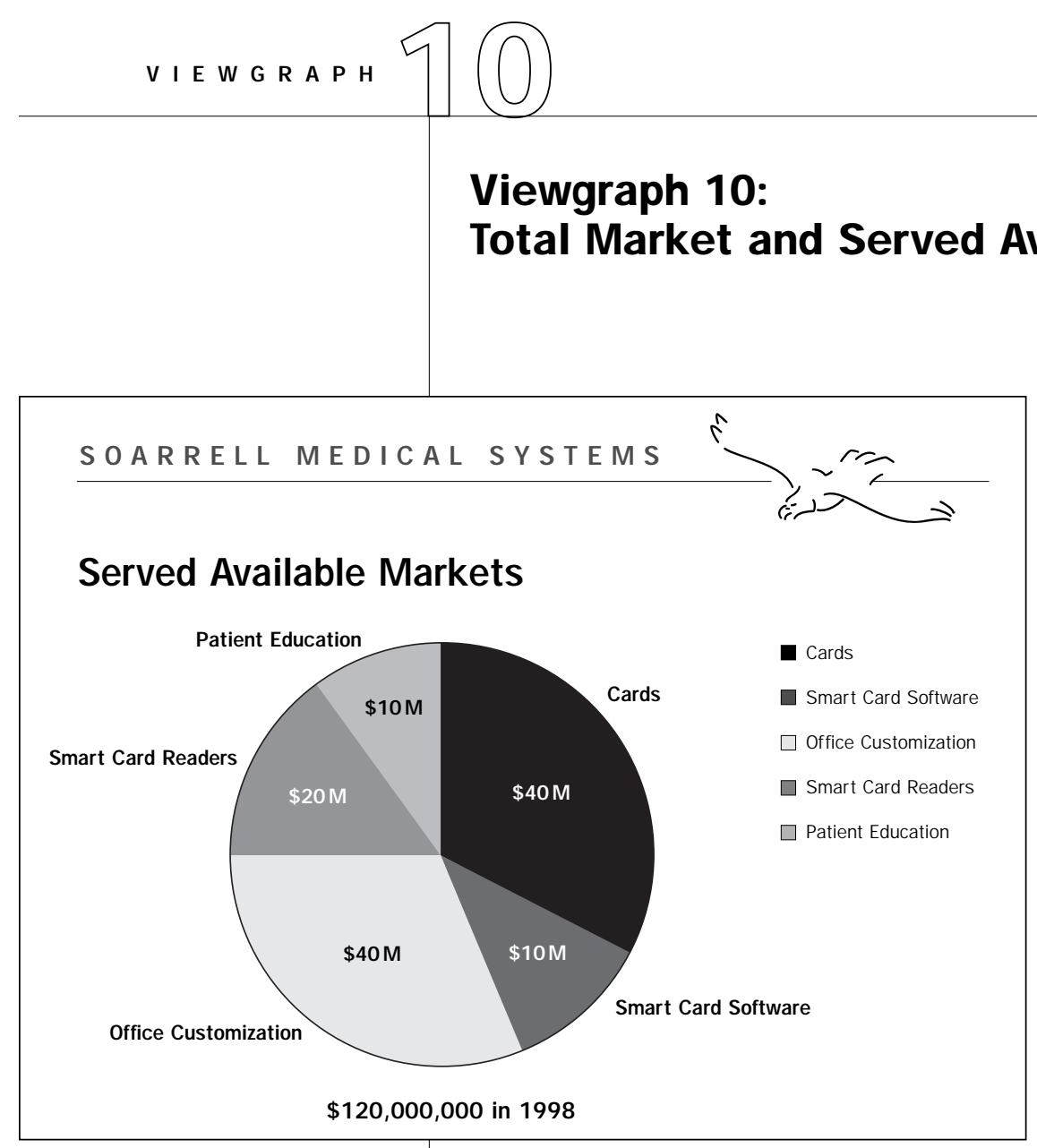

\section{What}

The phrase "size of the market" or "market size" refers to the annual potential of the market expressed in dollars, units, or both. This concept is applied to all segments for which the product is appropriate.

Another important concept to consider when sizing the market is the difference between the total market and the served available market. The served available market defines the market niche in which the company will operate in more precise terms. By contrast, the total available market is the larger, related market in which one is operating. The served available market is a subset of the total market.

\section{Why}

If the size of the served available market is too small, a potential investor will not be interested in investing because the return on investment (ROI) will be unattractive. If the market size is fairly small, the entrepreneur should reconsider whether the technology, product, or service is worthwhile pursuing or whether he should reconceptualize how he or she has segmented the market. As indicated previously, market segmentation is fluid and has profound "decision implications" for everyone involved. If the market is truly small, the entrepreneur may still decide to conduct business in this market. However, he should realize that if the market has a potential of under $\$ 50$ million and holds little promise of growth, it is unlikely that he will find an appropriate strategic partner or investor.

For assistance in developing this section of your presentation, see the Workbook Activities (7, 8, and 9) under Customers/ End-Users and Market

\section{Pitfalls to Avoid}

Sometimes naive entrepreneurs define the market size in numbers that represent a composite for " $\mathrm{X}$ " number of years, rather than in annualized figures. A better approach is to show the market size at a given point in time and then show 
predicted rates of growth. Just as a balance sheet is a snapshot of your financials at a given point in time, so is market size.

Entrepreneurs selling a system component typically make another error.

More often than not, when estimating the size of an emerging market, their tendency is to define the market size in terms of the annual sales of systems rather than the sales of components. When inducing market size in such situations, base your estimate of market size upon a sound model that reflects the projected selling price of the system and the number of components comprising the system.

There is also a tendency to confuse served available market with sales projections. Sales projections are tied to your goals for market share, not to market size. All you are doing by using the concepts of total market and served available market is attempting to define and quantify your market segment more tightly. You should revisit your definition of your market segment annually, and see if it merits redefinition. The entrepreneur's knowledge of the marketplace improves with experience, so it is common to redefine his or her market niche.

\section{Narrative}

We have used a market build-up method to estimate the size of the market potential for our system in 1998. We have come to a conservative but justifiable estimate of the market potential based on the number of doctors' offices which appear to currently be using a CPR system. The survey of CPR vendors indicated that eight of the most popular CPR vendors had their software in more than 100 sites and that they had multiple installations at most sites. Since we will be segmenting the market based on the installed base of the most popular CPR software, we decided to use these data. We assumed that the eight most popular systems were currently being used in over 800 sites (100 sites $x 8$ vendors), and that each served 5 different sites. If we estimate the cost of each component and multiply this by the total potential number of sites that would use this in 1998, we come to an estimated market size for 1998 of $\$ 120$ million.

\section{Highlights}

The presenter has built upon the information provided in the market segmentation viewgraph, and has provided the audience with an idea of the magnitude of the niche that will be pursued. 


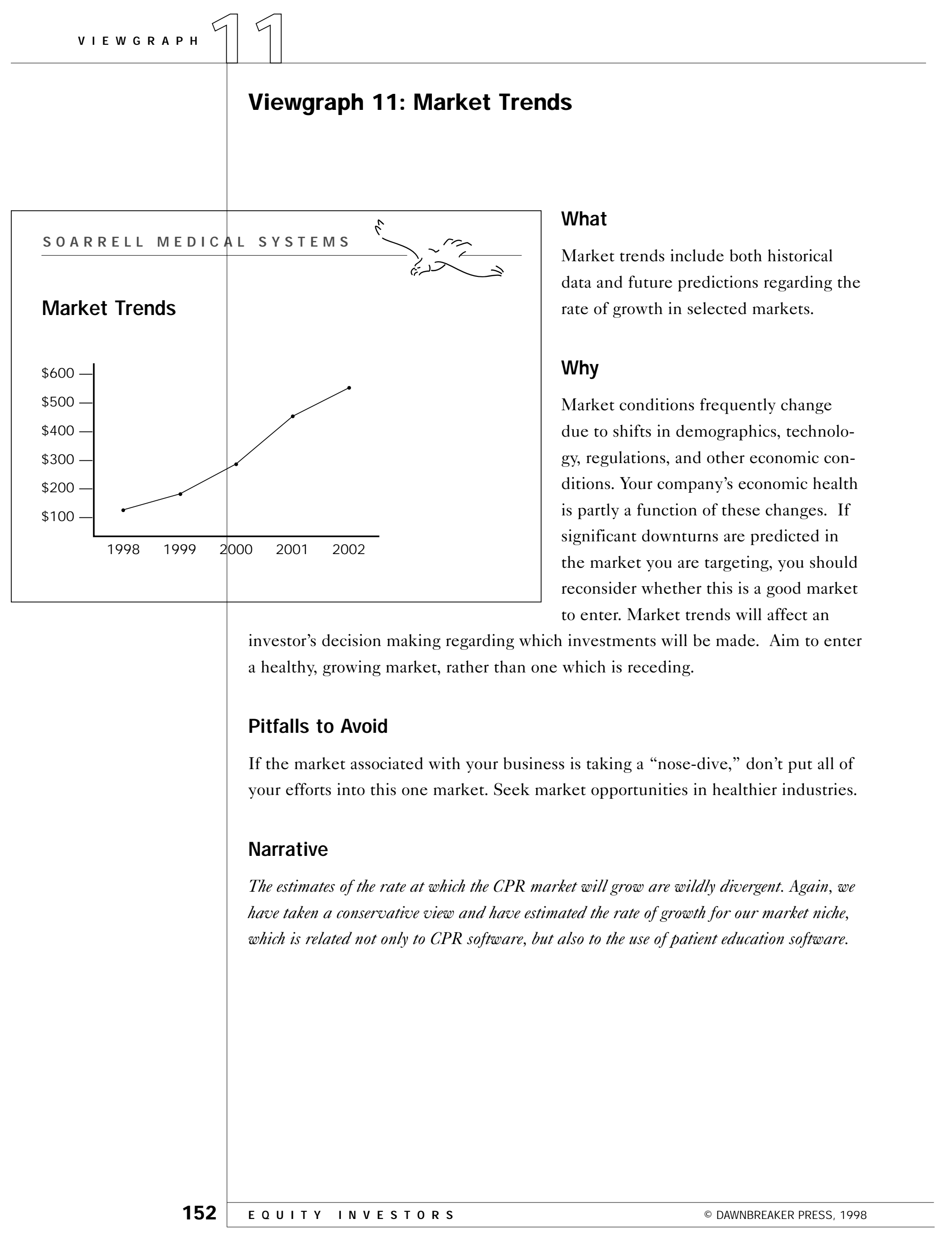




\section{Viewgraph 12: Competition}

\section{What}

You have presented information regarding the size of the market opportunity to your potential investors. Your presentation demonstrates that you have considered the various markets for this technology, product, or service and have defined an appropriate niche in which to grow your business. To interest a prospective strategic partner or an equity investor, the market upon which you have settled should be of sufficient size to merit an investment. Once your playing field is defined, you can begin the process of describing who else is in this arena.

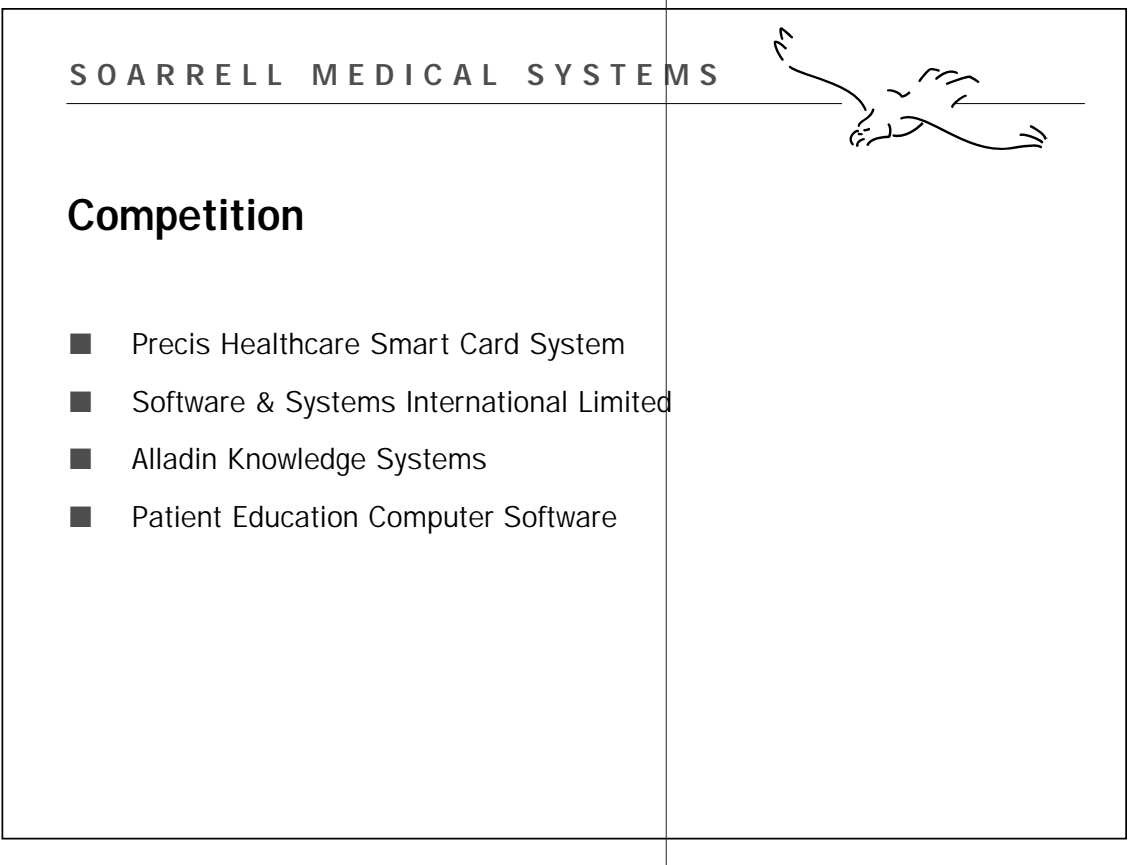

Why

Your success in making sales in the market you have defined will depend upon various factors. One important factor is who else is playing in this market. You need knowledge of your competitors in order to develop sound strategies and tactics that will enable you to take market share away from your competitors or to collaborate with them to jointly develop an emerging market.

\section{Pitfalls to Avoid}

This topic is often not adequately addressed. In thinking about competitors, some firms limit their discussions to companies that have a similar profile (i.e., other consulting engineering firms), or to companies that are working on the same solution (i.e., the same technology). Both approaches are inappropriate. There are many ways to fulfill a need-perhaps with your technology, perhaps with a quite different approach. For example, a company with a machine vision technology for sorting blemished fruit on a conveyer belt competes with human beings who visually scan citrus. These are clearly very different approaches for solving the same problem. You should consider as competitors all other individuals or firms working on the

For assistance in preparing this section of your presentation, see Workbook Activity 13. 
solution to the same problem, even if they are using totally different approaches.

The profile of the company doing the work is totally irrelevant to their definition as your competitor. Any firm working on the solution to the same problem as you are is your competitor, irrespective of its size, its mission, or its technology.

\section{Variations}

If you are conducting unique research in a critical technology area, it may be appropriate for you to omit names of competitors while highlighting differences among the approaches being taken to solve the problem and drawing attention to the advantages of your approach. If you are working in a more established field, you will want to draw attention to specific competitors and spell out how your technology, product, or service compares on FABs.

\section{Narrative}

This market is evolving in a very unusual way. Smart cards were developed in France and have been around since the late 1970's. Most commonly they are used as Loyalty cards or Electronic Wallets. A few companies have been using these in the health care industry including Healthcare Smart Card System and Software and Systems International Limited. However, none of these have the voice encryption algorithm, the patient verification focus, or the integration with patient education that our system offers. Another company, Patient Education Computer Software, focuses on patient education, but has nothing to do with smart cards. We believe that, for such health care related services, consumers would rather deal with a company that specializes in health care, rather than a smart card company which receives most of its revenue from other applications of smart cards. In addition, Soarrell's biometric voice encryption technology provides the firm with a strong competitive advantage over other health care systems products.

\section{Highlights}

There are always competitors. The presenter has used this viewgraph not only to introduce the competitors, but also to differentiate his product from the competitors' by highlighting his sustainable competitive advantage. 


\section{Goals and Objectives}

Viewgraph 13:

Goals

Viewgraph 14:

Objectives: Marketing and Sales

Viewgraph 15:

Marketing Communication Plan

Viewgraph 16:

Objectives: Research and Development

Viewgraph 17:

Research and Development Milestones/ Timeline

Viewgraph 18:

Objectives: Manufacturing/ Production

Viewgraph 19:

Customer Service 
- What are your company's goals for market share and return on investment?

What are your major milestones for marketing and sales?

What are your marketing tools?

What R\&D needs to be completed? What is the timeline?

What are the manufacturing/production milestones? What is the timeline? 


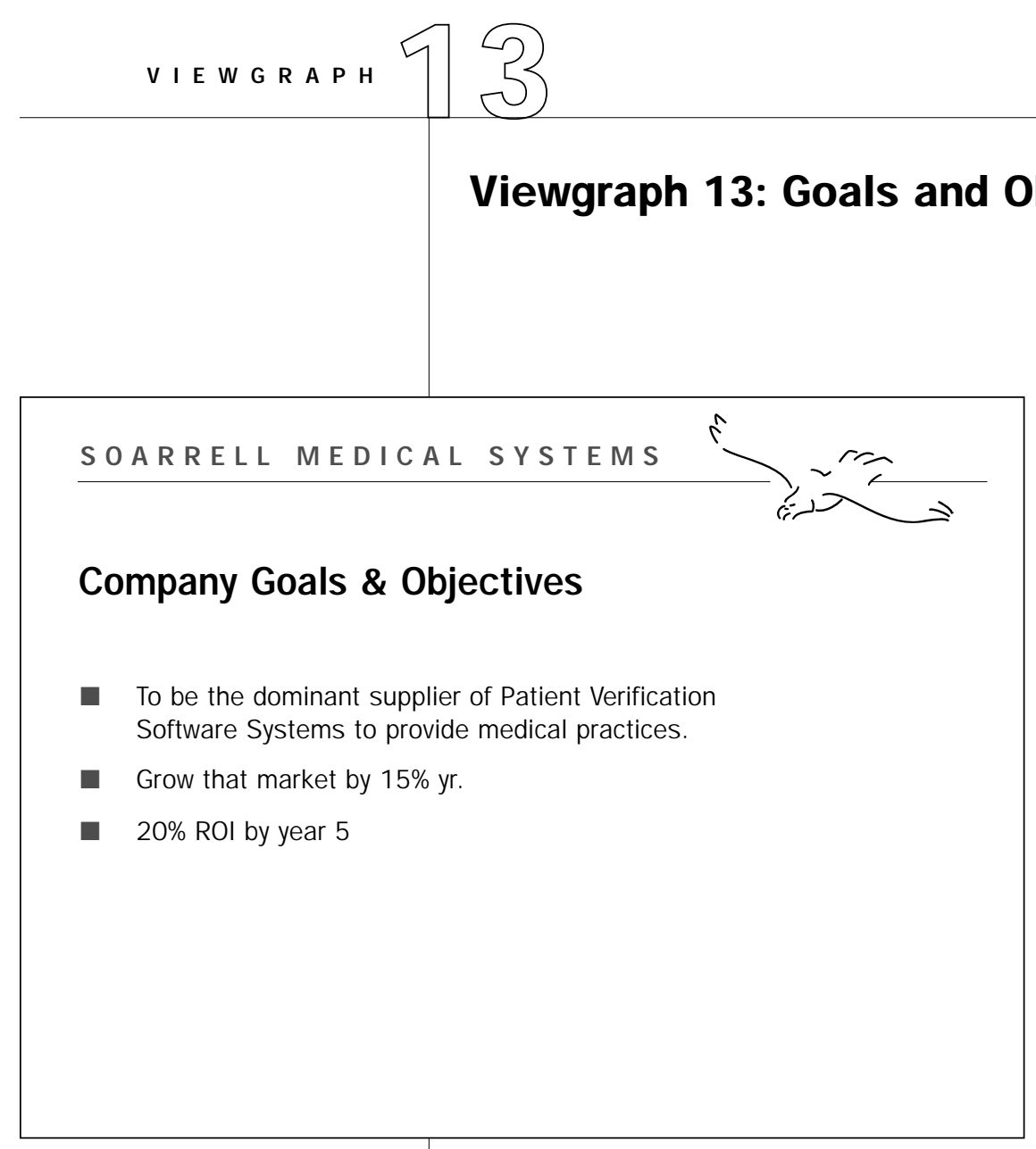

\section{What}

Up to this point, everything in your presentation can be considered as background, leading up to the punch line. The punch line starts here and crescendos throughout the rest of your presentation. With the first 10 slides, you told your potential investor about your mission, your technology, and the marketplace that you have carved out. The balance of your presentation is used to unfold your plan for creating value for both yourself and the investor(s). Begin by defining what your company will look like in five years. Focus on quantified terms that relate strictly to creating value. Common company goals include the following:

- Introducing $\mathrm{X}$ new products

- Achieving $\mathrm{X} \%$ market share

- Achieving ROI of $Y \%$, ROI of X\%

- Becoming the vendor of choice in $Y$ arena

- Licensing $\mathrm{X} \%$ of products into targeted markets

Why

"If you don't know where you are going, you will probably end up somewhere else." -Laurence J. Peter (Thomsett, 1990)

The plan of action that will unfold during the balance of this presentation is one that you articulated in your business plan. Its intent is to maximize the probability of realizing the goal that you have defined. 


\section{Pitfalls to Avoid}

The goals are not something that you just pull out of the air. They have a direct relationship to your mission, your knowledge of your market, your competitors, and your ambition. The plans you develop must be realistic in directing you in the successful attainment of your goals, in accordance with your mission.

\section{Narrative}

Our goal is quite straightforward. By using the "Annual Physical" as the episode of focus, our goal is to become the dominant supplier of Patient Verification Software Systems. The CPR market is very dynamic. It is our intent to take a strong lead in growing this market. We plan to obtain approximately $40 \%$ of the market within five years. By year five, we are targeting an ROI of $20 \%$.

\section{Highlights}

The presenter uses this viewgraph as an opportunity to reconfirm many messages introduced earlier regarding the market and Soarrell's intent to become a dominant player. The presenter conveys an aggressive stance in the marketplace and, therefore, poses specific information regarding financial objectives, percent market share desired, and the ROI targeted.

The ATP requires that proposers include goals and objectives in ATP proposals. However, during the post-award period, a company is expected to become more quantitative in the details provided. 


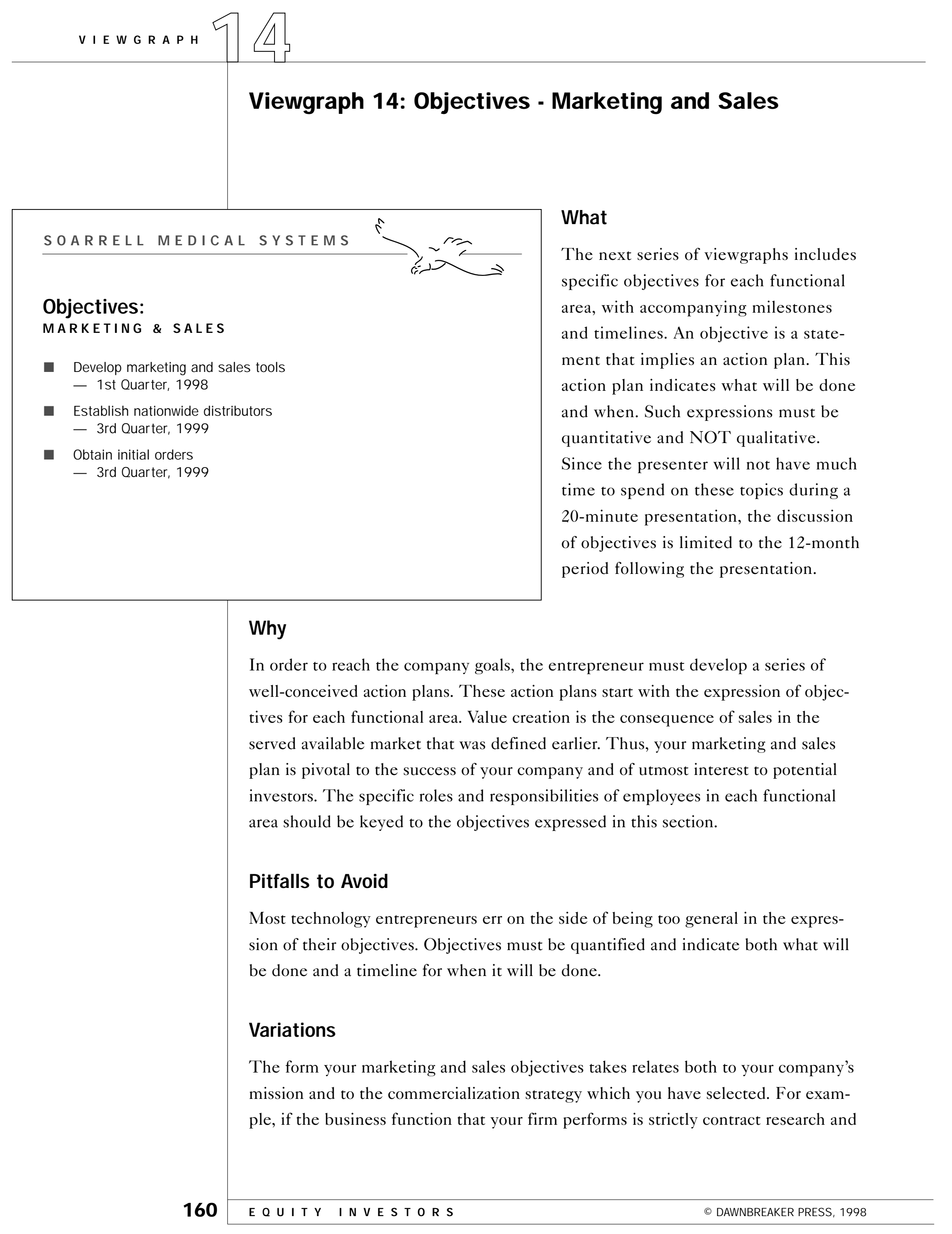


development and if you have selected licensing as your commercialization strategy, the nature of your marketing and sales objectives will be quite different from that of a manufacturing firm such as Soarrell Industries, which is illustrated below. In the licensing case, your customers would be potential licensees. Your marketing efforts would, therefore, involve the development of materials to be used in prequalifying and courting potential licensees. Your sales objectives would all relate to developing licensing agreements.

When making a presentation to potential licensees, exclude your action plan for marketing, distribution, and volume of sales from your presentation.

Including such information would be akin to telling a customer for a car what your strategy is for selling it to him. However, your business plan should clearly identify this information.

\section{Narrative}

Let's take a look at our marketing and sales objectives. During the first quarter of 1999, we will be developing specific marketing and sales tools to service a nationwide network. These tools will be in place by March 1999. John Doe's task during the second and third quarters will be to develop a cohesive set of 30 U.S. distributors. This is a formidable task. However, one of the larger CPR software developers has agreed to work with us.

Once the distribution network is in place, our task will be to obtain initial orders from each of the distributors.

\section{Highlights}

The presenter has indicated when each of these objectives would be fulfilled and has also quantified each objective. Such quantification will make it easier for the entrepreneur to chart progress during the year. This quantified information also helps potential investors begin to assess the adequacy of your action plan and its potential to create value.

Notice that the presenter subtly weaves in information that reveals existing collaboration with CPR software developers. This is useful information to share with potential investors because it reduces perceived risk. 


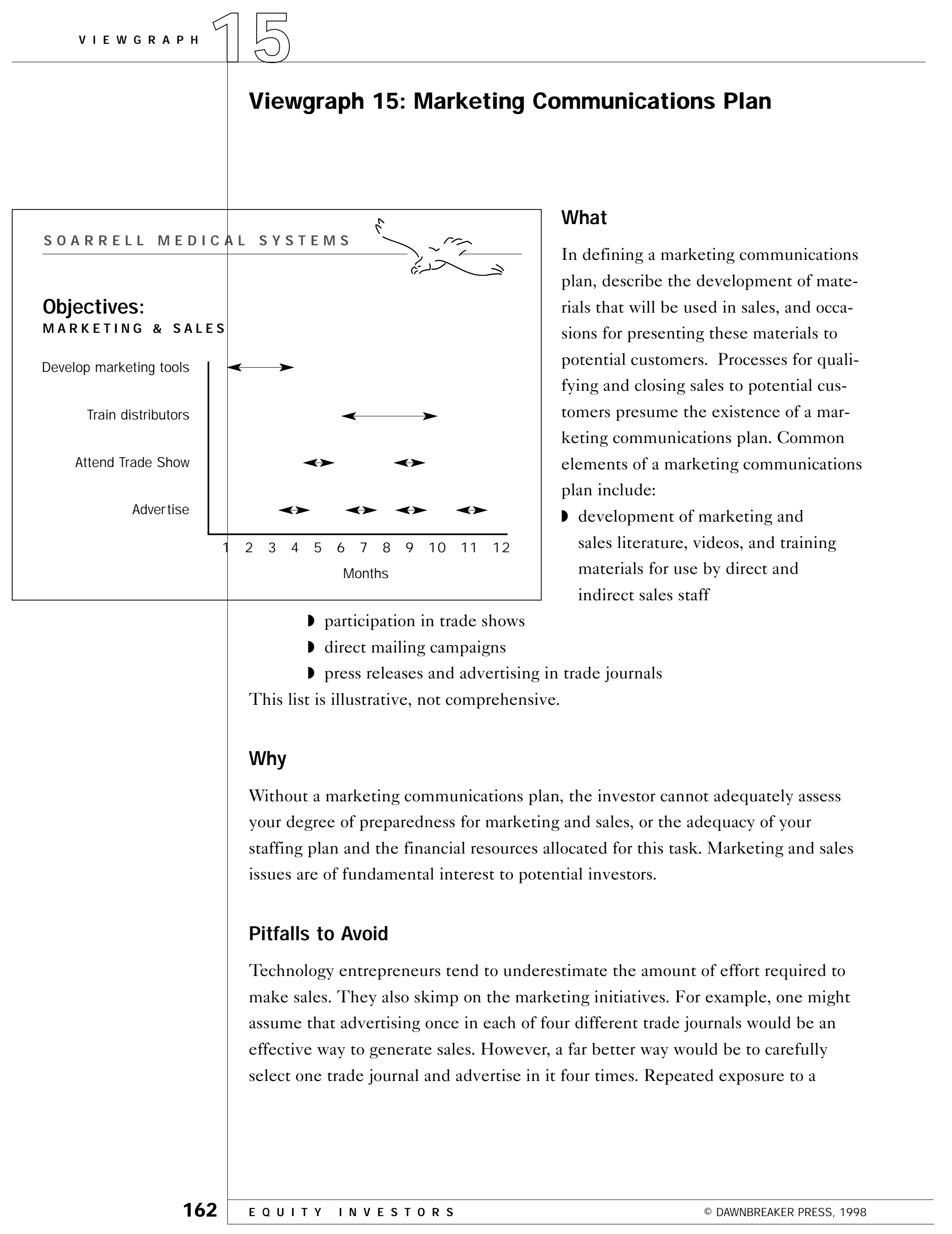


message is required for your potential customers to even notice that it is there. The other error that technology entrepreneurs make is to keep the marketing communications plan too general. Name the specific journals in which you will advertise, specify the dates and locations of the trade shows you will attend, and include appropriate cost estimates for all aspects of your marketing plan in your pro forma financials.

\section{Variations}

The specific items included in your marketing communications plan depend upon who your customers are and the most cost-effective way to reach them.

\section{Narrative}

This slide provides a timeline for execution of our marketing communications plan. As you can see, once the marketing and sales tools have been developed, training of our distributor network will begin. We will introduce the Annual Physical and Patient Verification Software System at two trade shows-The Healthcare Information and Management Systems Society show to be held in St. Louis in February and another trade show in Phoenix in September. We will begin promotion in print media at the end of the first quarter and will run a series of four advertisements in two trade journals starting in April.

\section{Highlights}

The presenter provided a fairly general graphic, drawing attention to the specific activities listed on the ordinate and adding mention of some specific information regarding events and dates. Given the brevity of time, the treatment of this topic is adequate and demonstrates to the investor that the entrepreneur has developed a detailed plan to communicate with his or her potential customers. 


\section{Viewgraph 16:}

\section{Objectives - Research and Development}

SOARRELL MEDICAL SYSTEM S

Objectives: $R \& D$

Smart card \& reader tested to complete specifications

- 1st Quarter, 1998

- Complete compliance with ISO 7816-4 guidelines

- 4th Quarter, 1998
What

In parallel with the marketing objectives mentioned earlier, the research and development objectives clarify what research and development will be done in a given time frame. You will notice that these objectives are fairly macro in nature, but still retain elements of specificity.

Why

The reason for expressing your objectives on a macro level is limited time. However, it is still important to mention research and development and demonstrate to the potential investor that you

have a plan for each functional area, i.e., research and development, engineering, and manufacturing, as well as sales. Delays in research and development, engineering, or manufacturing affect the rate at which sales can proceed. Therefore, it is important to demonstrate to your audience that all functional areas are working in consort to assure timely delivery of product.

\section{Pitfalls to Avoid}

The major risk for technology entrepreneurs is spending too much time on the discussion of research and development. If this is the presenter's area of strength, he has a natural inclination to focus on it. A benefit of being brief is to minimize the likelihood of divulging any proprietary information. 


\section{Variations}

If you have selected licensing as your commercialization strategy, it may be appropriate to include research and development objectives in your presentation. How you handle this topic depends on your licensing objectives and the stage of development of the item that you wish to license. For example, if you are looking to license your technology and also to obtain developmental funds to complete the final stages of development, it would be important to map out what needs to be done with these funds. However, if you have a finished product that is ready for licensing, the research and development plan would be inappropriate.

\section{Narrative}

Most of the true research and development has been completed. It focused on the development of a biometric voice encryption algorithm. Specifications testing with respect to the smart cards and reader remain to be accomplished. We have developed both of these fully cognisant of the ISO 7816 guidelines. We do not anticipate any problems-but some could be encountered.

\section{Highlights}

The research and development objectives are handled in a simple, straightforward fashion. The primary message conveyed to the investors is that little research and development remains to be done. This is important to convey at a time when the company is seeking funds to gear up for product introduction. 


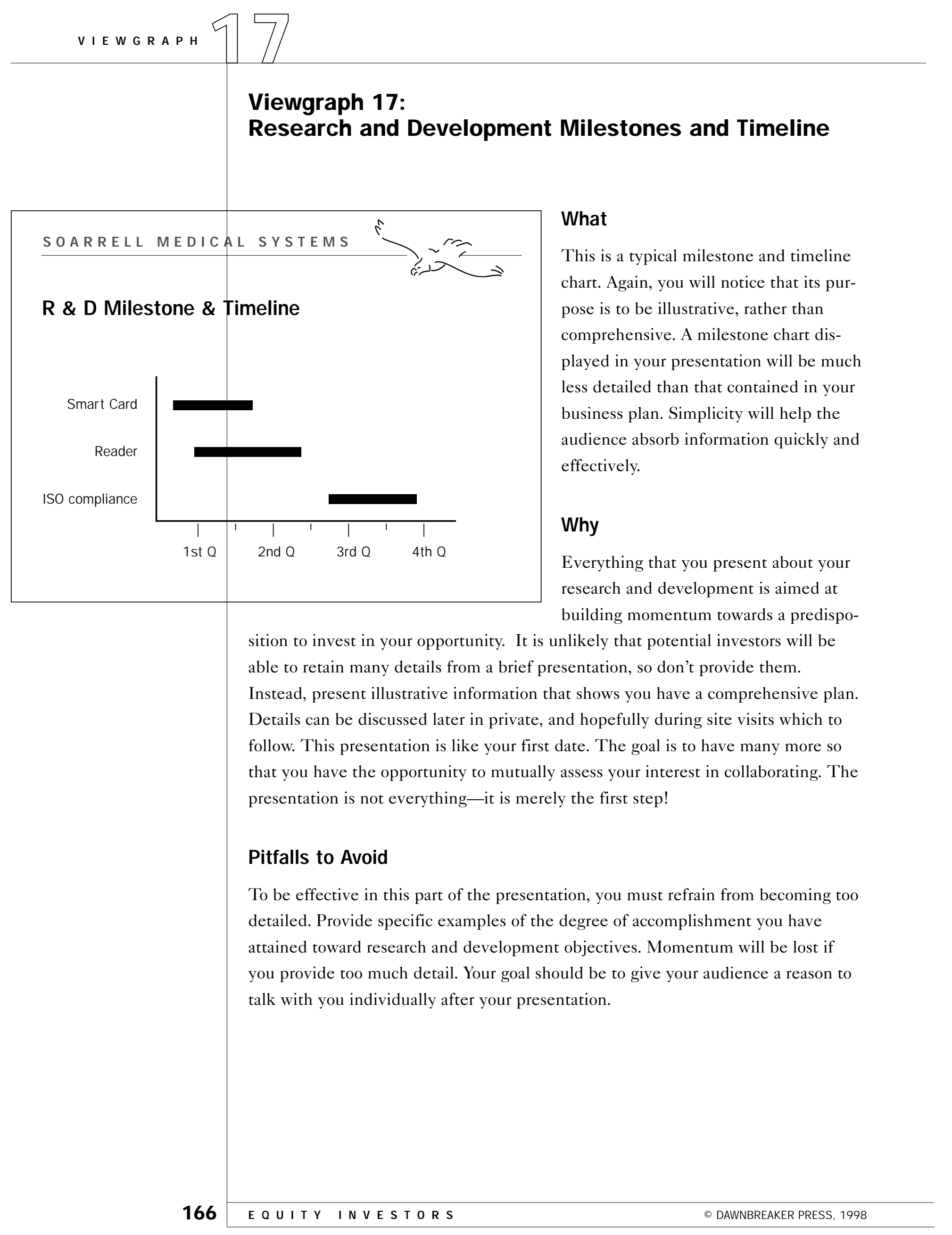




\section{Variations}

The variations to be made in this approach are a function of your technology and commercialization strategy. If you are seeking a licensing agreement with developmental funds to continue work on your product or technology, it would be appropriate to provide more details. Some of the other topics, such as marketing and sales objectives would be omitted.

\section{Narrative}

I've included a summary milestone and timeline chart to show you some of the specific items that we are working on. We are ahead of schedule on the evaluation of the smart card circuitry and are presently working on a few modifications to the reader. Although we have allowed ourselves three quarters to finish these tasks, I feel confident that we will complete the work by the end of the second quarter.

\section{Highlights}

Notice that the presenter did not mention each item on the viewgraph. That wasn't necessary given that the overall objective was to illustrate the items to be accomplished and to convey the message that the company was ahead of schedule. 


\section{Viewgraph 18:}

\section{Objectives - Manufacturing/ Production}

SOARRELL MEDICAL SYSTEMS

\section{Objectives: Production}

- Patient education archive

- Final review by content experts (2nd Quarter, 1998)

- Completion of manual to accompany Patient Verification Software - 3rd Quarter, 1998

- Low volume production run (smart cards; reader)

- 3rd Quarter, 1998

\section{What}

If your firm will be producing a product, either directly or through suppliers, it is appropriate to describe briefly your manufacturing, production, or service delivery plan. If you will not be producing a product, skip this section.

Why

There's a world of difference between saying that you can produce $\mathrm{X}$ and being able to deliver a high-quality product or service reliably. If you have not manufactured, produced, or provided a product or service before, this activity poses a high

degree of risk. Investors, customers, and suppliers need to be confident that you can deliver the volume of a quality product or service stated in your projected sales goals. Providing insight into your manufacturing or production plans will either foster confidence or engender dismay.

\section{Pitfalls to Avoid}

If you are producing only part of the product, don't skip this section! Even though you are not manufacturing a product in its entirety, you may still have points to make. Stakeholders will want to know how quality control will be maintained; if you have back-up suppliers; how good your suppliers are; and if you are planning to shift from a "buy" to a "make" strategy over time.

\section{Variations}

Use the most appropriate terminology in the title headings; i.e., don't always use the word "manufacturing." If you are producing a widget, manufacturing would be appropriate. However, if you are talking about software, then "production" is a 
more appropriate term. If you are delivering training, talk about materials development and production. When building a plant, a project development plan or a site plan would be a more appropriate way to refer to the activity.

\section{Narrative}

Soarrell will be producing the software containing our proprietary voice encryption algorithm, the patient education CD-ROM, and the internet materials. We will have a license manager associated with the software to prevent its inappropriate proliferation. By contrast, we have decided that it is more cost-effective to outsource the production of the patient smart cards to Siemens, under an appropriate secrecy agreement. Siemens is a leader in this field, and is able to meet our needs reliably at the appropriate quality level. All shipments of smart cards will be accompanied by a quality control report. All software and hardware will be shipped from our facility, under our label.

\section{Highlights}

What is important to notice is that the presenter uses this viewgraph to mention positive attributes regarding company activities. He does not merely present a litany of manufacturing objectives. The viewgraph is clearly laid out in a simple format, consistent with the style used for representing the marketing and research and development objectives.

If the company will be implementing a complex manufacturing plan, it is recommended that this viewgraph be followed with a manufacturing milestone and timeline chart. Since the manufacturing plan is not complex in this example, a Customer Service viewgraph is substituted. 
Viewgraph 19:

\section{Customer Service Objectives and Milestones}

SOARRELL MEDICAL SYSTEM S

\section{Customer Service}

- Attract and retain multi-functional team

- High quality on-site client orientation

- Proactively call client

- Internet support

- Fill orders within 1 day

\section{Narrative}

Customer Service will be a critical element of Soarrell's "Annual Physical and Patient Verification Software." Up to this point, I have mentioned production of components only for sake of clarity. Our Customer Service is what will make this package acceptable and will differentiate Soarrell from component providers.

In pricing Soarrell's product, our customers and we have decided to take a risk by accepting milestone payments. One upfront fee is followed by milestone payments during a six-month period, as measured by minimal disruption to the medical practice and increased patient satisfaction. In order to be successful with this approach, Customer Service is pivotal.

Our objectives are to attract and retain paramedics to be a part of a multi-functional sales and customer service team. Each team will consist of a paramedic and a software specialist. Other objectives are highlighted on this slide. I would be happy to discuss them in greater detail following this presentation. 


\section{Challenges/Requirements/Opportunities}

Viewgraph 20:

Risks and Contingencies

Viewgraph 21:

Constraints

Viewgraph 22:

Human Resource Requirements

Viewgraph 23:

Financials: Income and Expense

Viewgraph 24:

Financials: Cash Flow from Operations

Viewgraph 25:

Financing Needs

Viewgraph 26:

Investor's Return 


\section{Challenges/REQUIREMENTS/ OPPORTUNITIES}

- What are the risks of failure? What are your constraints? Use this discussion as an opportunity to show you are prepared!

- What are your human resource requirements? What is your timeline for acquiring them?

When will you achieve positive cash flow?

How much financing do you need and for what purposes?

- What will be the investors' return on investment? 


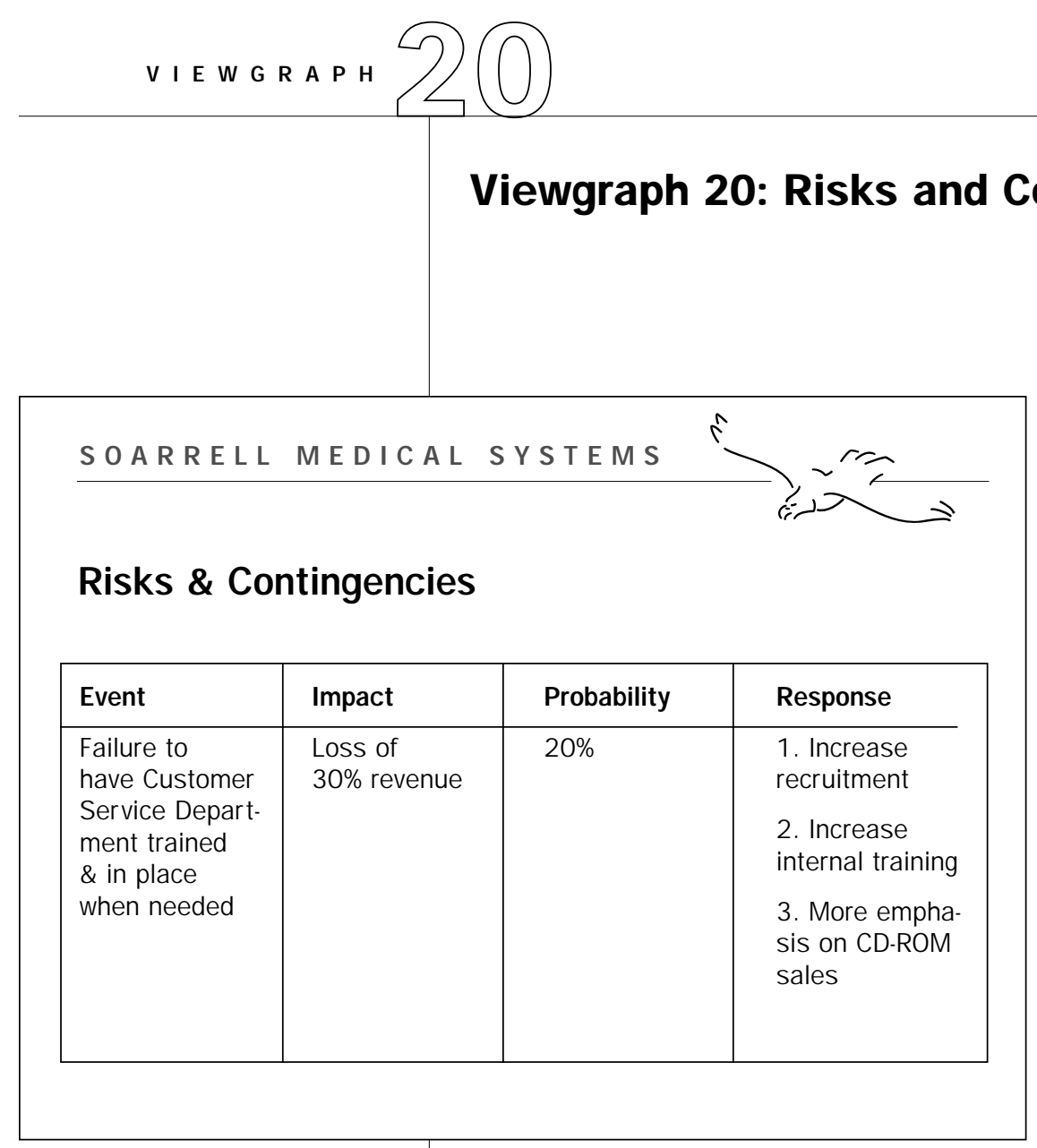

\section{What}

The risks and contingencies section of business plans and presentations often differentiates the mediocre from the excellent. There are always risks associated with business. The goal is to anticipate and prepare for them in advance, so that you can forestall many potential problems. Risks are associated with each functional area. There could be critical research and development tests that fail. Sales could proceed at a slower rate than predicted. Your competition could launch an aggressive price war to erode your market. In business anything is possible.

It is wise to assess the probability of occurrence of various events that could negatively impact your business. Prepare, try to forestall the events, or map out alternative plans of action for those situations that are beyond your control.

\section{Why}

Investors know that there are risks associated with their investments. It is important that they be able to assess the risks and determine if they wish to proceed. The biggest single risk for an investor is management. However, if you have done a thorough job of planning, you should be able to appropriately convey the strengths of your management team and minimize concerns about management risk.

\section{Pitfalls to Avoid}

To many technology entrepreneurs, sharing information about your risks is counterintuitive. In fact, it may not seem beneficial at first blush. However, by sharing information you convey your degree of preparedness. The discussion of risks and contingencies has to be presented in a positive light. Assure that your narrative doesn't come across as a litany of negatives; that would certainly be harmful! 


\section{Variations}

The nature of the risk that you select to discuss will again vary depending upon your company's mission and commercialization strategy. Do not be comprehensive in your treatment of this topic; use illustrations.

\section{Narrative}

When launching a new product, it is of utmost importance to evaluate the risks and contingencies relative to this new direction. We have evaluated all of the major foreseeable risks and have assigned a probability to each of them ranging from 0-100\%. For those risks which we evaluated as having a probability of $20 \%$ or greater, we have developed a contingency plan. As an example, we took a look at the potential risk associated with our Customer Service Department not being in place on time. We evaluated the probability of occurrence at $20 \%$. The potential loss to Soarrell would be approximately $30 \%$ of our income, given the manner in which we are sharing risk with the customer. By the way, our pricing method is a new trend in this field-and one that we have to use in order to break into this market.

We are not waiting, but have implemented three actions. We have (1) accelerated the rate of recruitment to the Customer Service Department, (2) enhanced internal training of our staff by Dr. Bolton, and (3) made a stronger thrust into selling CD-ROMs directly to patients. There is no risk sharing with direct customers of this sort.

\section{Highlights}

Notice that the presenter discussed only one risk and used this as an opportunity to reinforce that the company is prepared. It was clear that the assessment process used had already resulted in risk reduction; i.e., the three-step program involving Customer Service. 


\section{Viewgraph 21: Constraints}

SOARRELL MEDICAL SYSTEMS

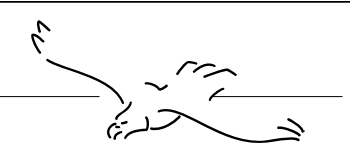

\section{Constraints}

- Customer Service Ranks

- Funds for adequate Marketing $\&$ Sales

- NOT all key functional areas are in place

- Unpredictable sell cycle (1 year)

\section{What}

The discussion of constraints is similar to the topic of risks and contingencies. In this section you are acknowledging those factors which could impede the growth of your firm if not addressed carefully.

\section{Why}

By describing constraints on your ability to meet your goals, you are in essence saying that you recognize that there are certain aspects of your firm which need to be strengthened. Investors will see this, once they start probing. By raising the issue, you are acknowledging its existence and taking the first step to overcome it.

\section{Pitfalls to Avoid}

Avoid being negative. Present the information as a sign of your strength and wisdom. Do not say things like, "We know that we're lousy with marketing and sales; that's why we're looking for a partner," or "We're technical people and we want someone else to do that other stuff." This also sends a negative message-and it doesn't work! The reason we are belaboring this is we have heard too many people initially address their constraints in this fashion. 


\section{Variations}

Depending on the audience and the nature of your commercialization strategy, you may decide to omit this viewgraph. Such frankness is useful when seeking equity investors, but is not relevant if you are presenting a licensing opportunity. Also, you could combine the discussion of constraints with the treatment of contingencies and then eliminate this viewgraph.

\section{Narrative}

Realistically, one must look inwardly and evaluate the overt constraints on the success of Soarrell Medical Systems. The key to our success is that we recruit talented individuals to fill the positions identified in the organizational structure that I will show you momentarily. We also recognize that, given the dynamic nature of this field, we could either experience a slow sell cycle initially or such a fast one that it outstrips our capabilities. Key to our success in overcoming the constraints is the timely infusion of first-round financing.

\section{Highlights}

Note the tone of the narrator and that what he is saying does not exactly duplicate the words in the accompanying viewgraph. The messages compliment each other well. 


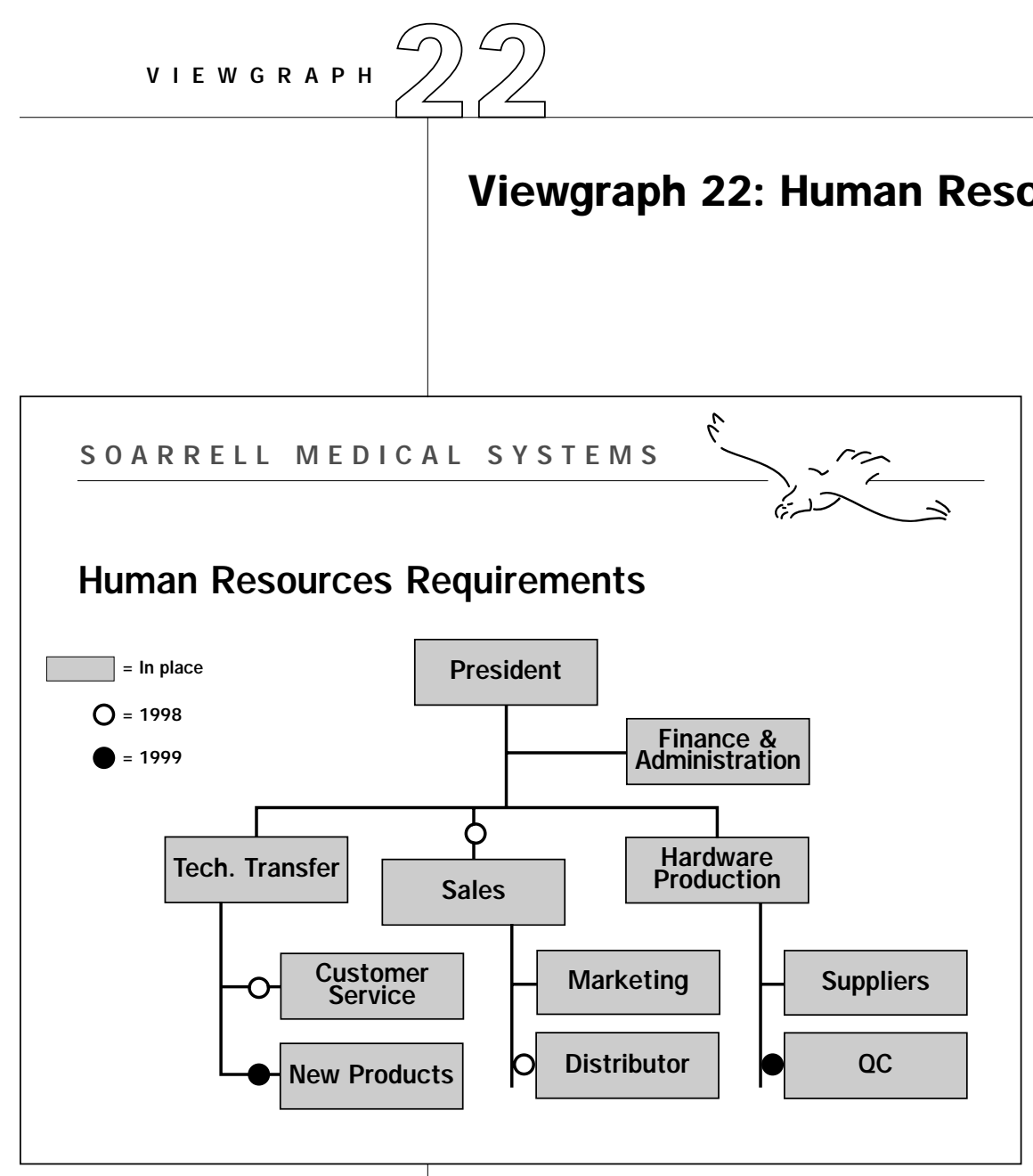

\section{What}

The purpose of this particular viewgraph is to show the human resources that will be required to attain the goals and objectives you have set forth.

\section{Why}

It is common for technology entrepreneurs to underestimate the resources that will be required to bring products to market successfully. The reason for including a phased organizational chart is to demonstrate that you have anticipated the resources that will be required to drive your company. A phased organizational chart allows you to show in one graphic what the company will look like over the next three to five years. The key, evident in the upper left-hand corner of the viewgraph, enables you to show when functions will be added. If you wish, you can place numbers in each box to indicate the number of hires in each functional area at each point in time.

\section{Pitfalls to Avoid}

With the numerous discussions in the popular press about organizations becoming flatter, some technology entrepreneurs have been representing their organizational structure in novel ways. They tend to show that there is little differentiation among people. Such a chart may be useful internally, but for conveying resources to potential investors, it is better to represent your organizational structure in a more conventional manner. Your organizational charts should show roles and responsibilities and a chain of command. 
Another common error that many entrepreneurs make is to put their name in all the management positions. Again, this is not viewed favorably. One person cannot adequately grow all aspects of a company beyond a very limited point. If you plan on accelerating the growth of your firm, it would be safer to represent functional areas without names and to seek additional staff promptly.

\section{Variations}

Another common way to represent human resource requirements is by using a table. List years as column headings, and use functional areas as headings for each row. Then enter the number of people that will be working in each functional area by year into each table cell. Be sure to include staff totals at the bottom of each column.

\section{Narrative}

Soarrell Medical Systems has a sound plan for growth. Currently, we have three key people on the management team in place in Tech Transfer, Finance and Administration, and overall company management. In order to accelerate the market's awareness of our products, in 1999 we will be adding people to marketing, customer service, and distribution. We are looking to expand our cultivation of the market further by teaming with a large CPR provider who has an existing distribution network in place. Since our near-term focus is product introduction, we will be adding a fourth party to our management team during the fourth quarter, to head up the Customer Service Area.

\section{Highlights}

Notice that the presenter is beginning to weave in themes that were mentioned at the outset. Here again, he indicates an interest in teaming with a CPR provider who has existing distribution networks. At this point in your presentation, begin to add narrative that relates back to the business opportunity. 


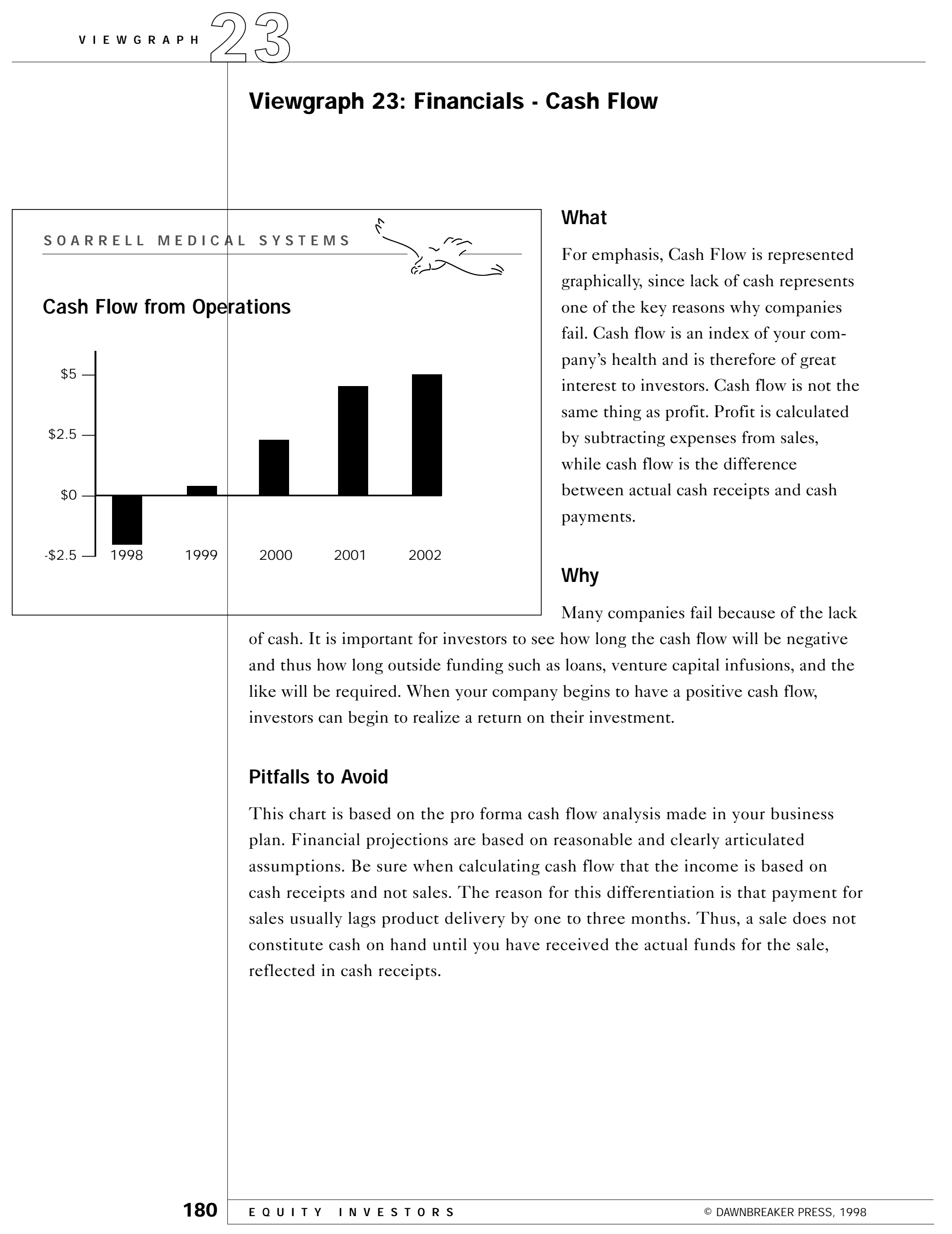


The years indicated on the horizontal axis should correspond with the dates when you anticipate an infusion of funds from your potential funding source.

\section{Narrative}

We will need an infusion of funds during each of the next two years to cover the costs associated with product introduction and customer support. In 1999, as our early sales are made into the markets, we begin to see a positive cash flow. With the development of a teaming relationship with a major player in the CPR industry, our projected sales will accelerate. By 2002, we will have a very healthy cash flow position. 


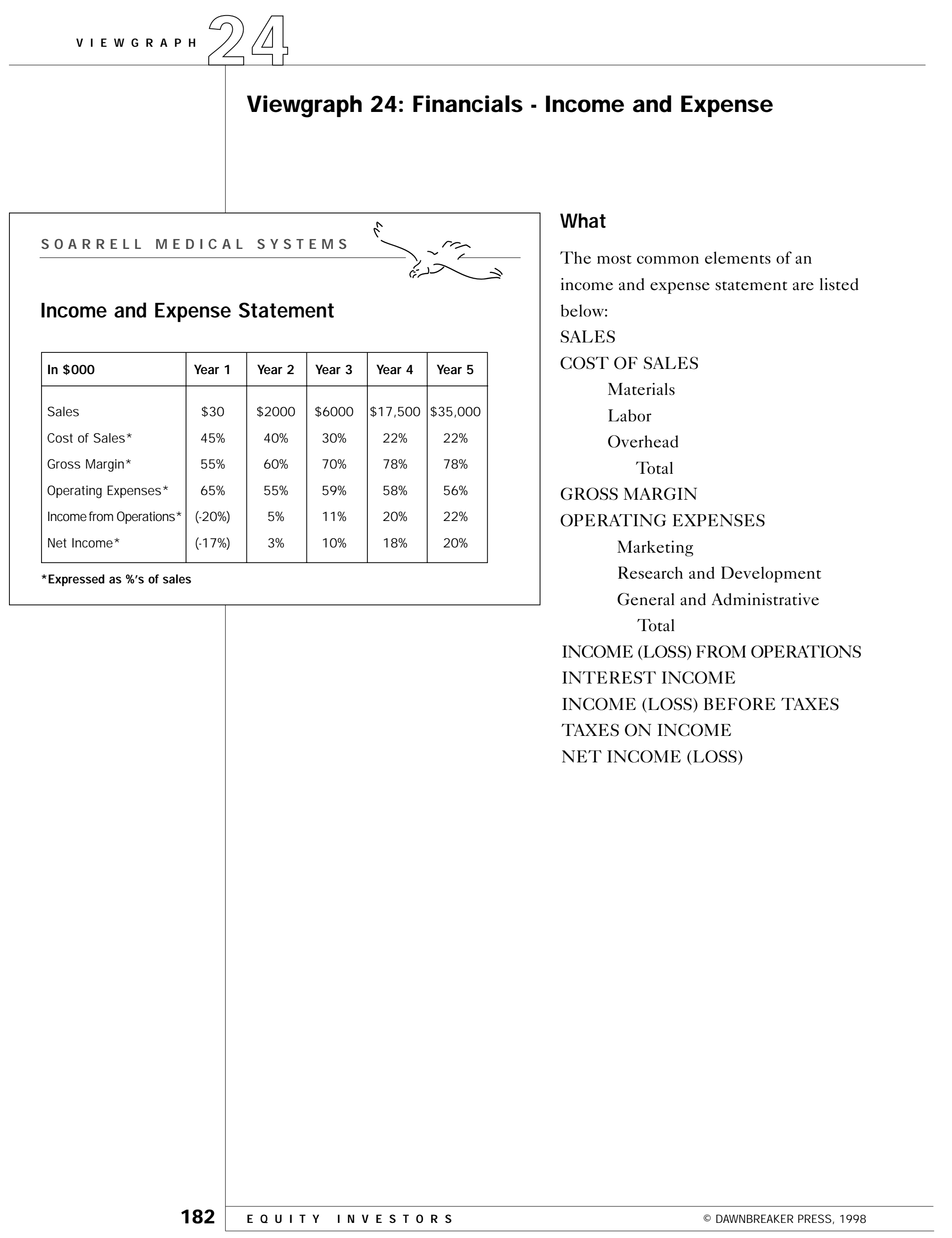


There are many variations on this theme. However, you need to keep things simple so that the information can be grasped quickly and retained.

\section{Why}

This is indeed the bottom line. You must present your financial highlights clearly and simply.

\section{Pitfalls to Avoid}

Avoid presenting too much data. You don't want to lose your audience. Although this presentation is simplified, the financials in your business plan should be well developed and comprehensive.

\section{Variations}

You can represent the financial information in absolute numbers and/or percentages. In the viewgraph presented on the following page, absolute numbers were provided for the sales forecasts only. Everything else was represented as percentages of sales. To make the message more salient, some elements of a typical income and expense report were omitted.

\section{Narrative}

In year one, our projected sales will be modest. However, our distribution channel will be in place and sales volumes will accelerate. By year five, we project sales of $\$ 35$ million. At the outset, the cost of sales will be relatively high, as we will be developing a new distribution channel and selling to a somewhat conservative market. However, a variety of enabling complementary technologies that are expected to become available during the next two years will provide the impetus for more rapid growth. When we finaliwe our teaming arrangement with the CPR provider, our cost of sales will decrease. By 2002, the fifth year of operation, our net income will stabilize. In that year alone, our net income is projected to be $\$ 7$ million.

\section{Highlights}

Notice that the presenter only draws attention to the most salient items in this verbal presentation. Details can be addressed individually in one-on-one conversations. As appropriate, the entrepreneur may want to compare these percentages to industry standards. 


\section{Viewgraph 25: Financing Needs}

SOARRELL MEDICAL SYSTEM S

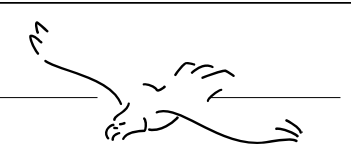

Financing Needs

$\$ 2$ million in two definitive stages:

- First-round financing $\$ 1$ million for customer service and product introduction - 3rd Quarter, 1998

- Expanded Marketing and Sales

- 3rd Quarter, 1999

\section{What}

You must articulate clearly what your financing needs are. Tell potential investors how much money you need, when you need it, and how it is to be used. Also mention other needs potential investors might help you meet-for example, expertise, contacts within the industries of interest, and the like.

\section{Why}

Although it should be obvious why potential investors need to know this, some entrepreneurs refrain from clearly articulating this information in their presentation.

\section{Pitfalls to Avoid}

Be careful not to demand financing. Your presentation should be a request. The manner in which you present your financing need should clearly convey that you are looking for a partner, not just a backer. 


\section{Variations}

There are many possible financing arrangements. You should explore these options thoroughly during your business planning.

\section{Narrative}

We are seeking a total of $\$ 2$ million in two rounds of financing. We need $\$ 1$ million to attract and retain a multi-functional marketing and sales team, expand the customer support function, and begin the product introduction process. Ideally, we are looking for a venture capital firm with strong ties to the medical practice management industry to provide this first round of funding. Our preferred commercialization strategy is ultimately to team with a major medical practice management software developer and to be acquired by them in year five. We will seek our second round of financing from a strategic ally who will have the option of purchasing Soarrell Medical Systems in year five. The acquisition price would be twice sales OR at a capitalization rate reflective of this industry. It will be established by an independent third party at the time of the potential acquisition. 


\section{Viewgraph 26: Investor's Return}

SOARRELL MEDICAL SYSTEM S

Investors Return

Venture Capitalist

Acquisitions in year 5 at $5-10 x$ on initial investment

Management buy-back

CPR-Open up profitable, new market

Prevent competition from gaining market share
What

This section of your presentation specifically addresses the financial return to the investor; i.e., the value created. (This is not the same as the social rate of return you were required to address in your ATP proposal.) Value may be expressed in numerous ways including Return on Investment (ROI), Return on Assets (ROI), and Book Value. The level of return investors seek will vary with the type of investor. Institutional investors typically want a minimum return of $5 \mathrm{x}$ on their investment within five years. A strategic ally will often accept a lower ROI (15-25\%). This may occur when the capabilities of the potential acquisition enhance the ally's competitive position or increase its revenue generation capabilities through savings or new revenue generation opportunities. The $20 \%$ ROI targeted by the Soarell management team would be acceptable to a potential strategic ally, but would not hold out much appeal to an institutional investor. Therefore, the company might want to buy back its stock in the event that the strategic ally does not acquire the firm, and/or the company might need to reconceptualize its commercialization strategy.

The management team has presented a sound plan for growing this market and has a good intellectual property position. An investor with ties to the CPR market might see the potential in a different way and ask the management team to rework their numbers with a different set of assumptions. A more aggressive approach to the marketplace might result in a higher ROI.

Why

Value creation is at the core of an investor's business. It must be addressed from the investor's perspective. 


\section{Pitfalls to Avoid}

The most common mistakes technology entrepreneurs make are: (1) failing to address the investor's return at all in their presentation, or (2) announcing how much equity they are willing to give up in exchange for financing. Failing to address an investor's return reinforces the belief that the technology entrepreneur is simply looking for a source of capital to continue research and development and is not interested in creating value. If you are seeking money from the private sector, approach the search responsibly and knowledgeably.

The amount of equity that will be offered should be negotiated privately, after further meetings and greater understanding of investor's requirement. A figure you pose in your presentation might be much higher than you would need to provide, or so small as to seem ludicrous. However, you should have made some private decisions about how much equity you are willing to relinquish and checked with colleagues knowledgeable about the financial community to determine if your decision is reasonable. Be prepared, but negotiate equity sales privately.

\section{Narrative}

As was mentioned earlier, we are looking to provide our investors with a 20\% ROI. As this market continues to evolve, we will have to be a larger company to supply the market. Therefore, we are growing this business with the intent of being acquired within five years by a large firm in the practice management arena.

Key to our success is forming a successful strategic alliance with a CPR firm that has an existing distribution channel. This partnership will bring an additional product to add to the distribution channel, and enhanced customer satisfaction, and increased market share.

I will be available to talk with any interested parties after this presentation. I have an executive summary from our business plan and other literature which I will be glad to share with you. Thank you for your attention.

\section{Highlights}

The presenter has woven together a number of the themes and financial highlights mentioned previously in his presentation and has closed with a clarification of how value will be created for the equity investor and the strategic alliance partner. 


\section{Synthesis}

This sample presentation to potential investors or allies marks the end of this section.

The following collection of activities can be used by the technology entrepreneur with or without the assistance of an experienced guide. The activities should be completed prior to preparing the viewgraphs or other documents used to present your business opportunity to others. Completing these activities will help assure that you are prepared to meet the challenges that lay ahead. 
Section 3 


\section{Prelude}

$T$ he ATP program is designed to promote U.S. competitiveness by supporting highrisk research and development in technology areas where there is substantial potential for enhancing U.S. economic growth. The program has been highly successful in getting small, innovative firms to participate. Companies that receive ATP awards face many immediate challenges, due to the innovative nature of the technology being funded as well as the increased publicity the firms face after receiving an award. These challenges include:

D Having to deal with many suitors for "hot" technologies

- Having to develop more complex commercialization strategies

- Learning to focus in the context of a rich technology platform

- Having to develop more sophisticated planning

- Having to adapt to a more rapid learning curve

The focus of the basic concepts section was to provide information to enhance a more rapid learning curve and better decision making by small firms. Information, however, is never enough-it is only the starting point for action.

To facilitate action, the last section of this book contains a collection of activities to be addressed by the technology entrepreneur, either alone or with the assistance of an experienced, motivating mentor. As we have said earlier, such assistance could come from members of the company's board of directors, advisors, state service providers, or consultants. The role of the advisor is to help a company maintain a delicate balance between keeping these award-generated activities in the forefront while not distracting its management team from the company's core business.

\section{Organization of Workbook}

The activities included in the workbook relate to four content areas. Each has a direct bearing on the commercialization strategies you choose. These content areas include:

- strategic planning

D customers/end users

D market

D competitors
Of the 311 single applicant awards made since 1990 , 212 have been made to small businesses.

Many of these issues will have been addressed by ATP awardees to some degree. One's understanding of the business environment and the best response to it, however, is dynamic and on-going. 
Commercialization Toolkit ${ }^{\text {TM }}$

- Strategic plan

- Licensing Package ${ }^{T M}$

- Business plan

- Presentation

Do activities and then package.

Commercialization Toolkit ${ }^{T M}$

is discussed in Chapter 1.
FIGURE |||-1:

A DVANCED ORGANIZER

ACTIVITIES
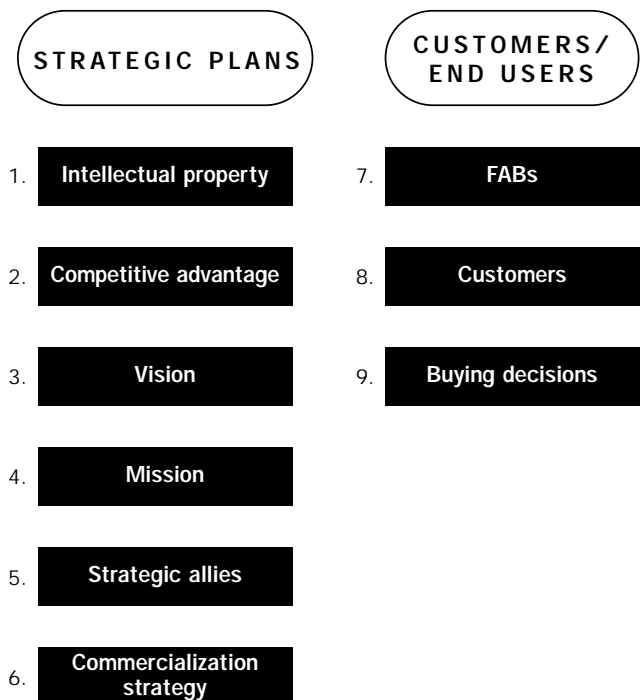

MARKET

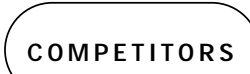

Market segmentation

13

Who are they?

\section{FABs}

Buying decisions

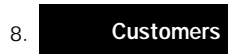

Market size

Market growth

Figure III-1 is an advanced organizer representing the topics covered in this chapter. There are fourteen activities in all, relating to strategic planning, customers, markets, and competitors. It is highly recommended that the reader complete all pertinent activities prior to developing the various documents in the Commercialization Toolkit ${ }^{\mathrm{TM}}$. The activities contained in the Guide will assist in the development or revision of a strategic plan, licensing package, business plan, or presentation materials. An additional resource to consult for activities related to the development of operational plans is Business Planning for Scientists and Engineers (Servo, 1999).

When confronted with today's financial imperatives, planning is easily pushed aside. In order to increase the likelihood that good intentions result in successful action, start by setting up a schedule for completing the selected tasks. To obtain an objective assessment of your strengths and weaknesses, it is recommended that you start this process by consulting with a respected advisor. Then, complete only those activities that are relevant for you.

A strawman schedule for completion of various commercialization activities is listed below. This schedule will not meet all company needs. 
FIGURE III-2:

SCHEDULE FOR DEVELOPING COMMERCIALIZATION TOOLKITTM

READ

WORKBOOK ACTIVITIES

DOCUMENT ENHANCEMENT

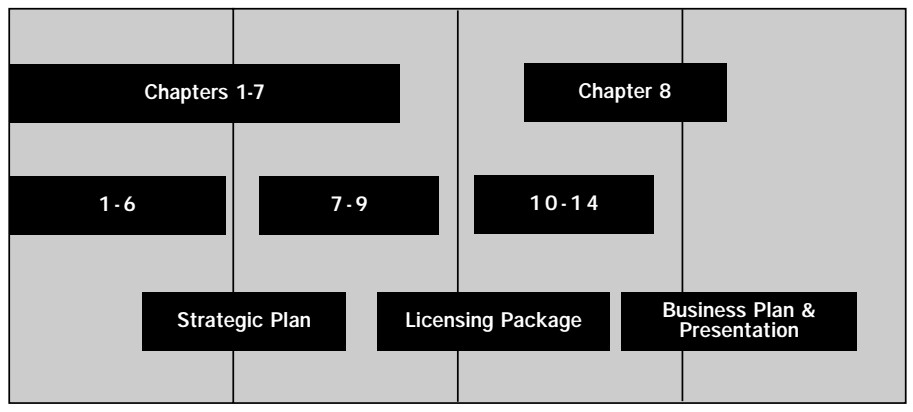

ATP Award

Announcement Start

6 months $\quad 12$ months

TIM E 
Related Activities:

Activity 1:

Intellectual Property

Activity 2:

Sustainable Competitve Advantage

Activity 3:

Vision

Activity 4 :

Mission

Activity 5:

Srategic Allies

Activity 6:

Commercialization Strategy 
$\mathrm{T}$

he activities in this area of the Workbook (Activities 1 - 6) are intended to help management thoroughly consider fundamental issues related to strategic planning. The greatest headway with these tasks is often made in an off-site session, where interruptions can be minimized. If you intend to involve your board of directors in the planning process, an off-site meeting could be held in combination with a board of directors meeting.

To help synthesize the information resulting from these activities, we recommend that you begin work on a strategic plan for complex technology platforms (Chapter 4) following your planning sessions. Completion of this plan will require research on customers, markets, and industry trends. 
A recommended low-cost resource for technology entrepreneurs is a very readable magazine entitled

The Law Works:

The Law Works

1935 S. Plum Grove Rd., Suite 158

Palatine, Illinois, 60067

(708) 705-7195

The subscription cost is approximately \$45 per year. Call and ask them to send a sample so that you can assess its potential value.

\section{A recommended book on} intellectual property is Patent It Yourself, by David Pressman, Esq. This extremely readable book contrasts copyrights, trade secrets, and patents. It focuses on helping the reader understand the process of conducting a patent search, as well as filing and prosecuting patent applications.

\section{Intellectual Property}

One of the most significant changes during the past four years is the provisional patent application process. According to "Important Notice for Inventors," issued by the Patent and Trademark Office:

"As of June 8, 1995, inventors will be able to file a provisional application that will allow them to obtain an early filing date with few formalities and at a lower cost than filing a non-provisional application. This new application differs from a non-provisional application because the patent term does not start from this filing date, the application is not examined, and it cannot issue as a patent. The provisional patent application is retained in confidence and is automatically abandoned 12 months after filing. Before the provisional patent application expires, the applicant must file a non-provisional application to obtain a patent.

To file for a provisional patent application inventors should include:

D a clearly written description of the invention

D any drawings needed to understand the invention

D the filing fee of $\$ 150$ ( $\$ 75$ for small entities), and

D a cover sheet identifying the inventor(s) name(s), residence(s), invention title, name and registration of correspondence address, and any U.S. Government agency that has a property interest in the application.

The inventors now have up to 12 months to file a non-provisional patent application under 35 US Section 111 (a) and claim the benefit of the provisional application filing date."

For specific details about changes in U.S. patent law, please call the Patent and Trademark Office (PTO) at (703) 305-9300. For questions concerning any changes in the rules of practice before the Patent and Trademark Office, call (703) 305-9282.

At first blush, the provisional patent application may seem to bear similarities to the disclosure document program. However, the two are significantly different. The disclosure is used as evidence, whereas a provisional patent application is indeed an application. The 20-year clock does not start ticking until the formal application is filed. The major benefit to an inventor is that he can file a provisional patent application with a $\$ 75$ fee and receive a patent pending status. This enhances the inventor's ability to interact with potential allies. One must then file the formal patent application within 12 months; otherwise the patent application will be abandoned. Consult the PTO with any questions. 


\section{Activities}

Make a list of the intellectual property your firm has protected, noting the dates when patents, copyrights and trademarks have been filed or issued. If you find yourself indicating that your technology is "patentable" but have done nothing toward that end, start giving serious consideration to how you will protect your intellectual property.

\section{WORKSHEET: ACTIVITY 1: INTELLECTUAL PROPERTY}

DATE

INSTRUCTIONS: Use this area to generate a list of your current and pending intellectual property. With pending intellectual property, be sure to take action. You don't want to revisit this page in six months and find that nothing has changed.

Title

Date

Responsible party

Issued Patent

Pending Patent

Unfiled Patent Application

Copyright

Trademark 


\section{Sustainable Competitve Advantage}

Sustainable competitive advantage is the collection of characteristics which provide your firm and your technology/product with clear advantages in terms of cost, speed, exclusivity, and effectiveness in meeting genuine customer needs.

Competitive advantage is required for the long-term health of any company.

The types of things that provide a company with a sustainable competitive advantage include:

D intellectual property, e.g., patents, trade secrets, copyrights, trademarks

D the uniqueness of the technology and the limited number of people who have expertise in this area (hopefully many of them are employed by your company)

D cost of entry

D other advantages that enable you to be quicker and less expensive

D your record with respect to selecting successful new products or technologies, as well as your ability to keep to development timelines

D other organizational strengths such as your marketing and sales capabilities, access to distribution networks, and the quality of your work

D your strategic alliances and champions

\section{Have I answered this question adequately?}

Result: Your goal is to develop a list of those characteristics that comprise your "sustainable competitive advantage" and then to condense this list into a succinct statement of fewer than 50 words. 


\section{WORKSHEET: ACTIVITY 2: SUSTAINABLE COMPETITIVE ADVANTAGE}

DATE

INSTRUCTIONS: Use this area to generate a list of those items that contribute to your sustainable competitive advantage. Then, generate a succinct statement that clearly expresses the competitive advantages of your company.

INTELLECTUAL PROPERTY: (This is the activity you just completed ((Activity 1)). Be sure to reference the information in your succinct statement.)

PERSONNEL:

COST OF ENTRY:

TRACK RECORD:

STRATEGIC ALLIES:

OTHER:

50-word statement of sustainable competitive advantage 


\section{What is Your Vision?}

Management can't begin to map out financial, marketing, research and development, and manufacturing strategies until it decides upon a direction for the company's future. Many companies approach their growth strictly in an opportunistic fashion. Although a company should always remain open to opportunities, without a vision for the future, a company will not be able to propel itself forward in a purposeful way.

\section{Activities and background:}

The management team should spend time sharing visions for the future around each of the items listed below. This requires at least four hours of uninterrupted time. An off-site meeting may be the best way to make sufficient headway with this activity.

\section{(1) PRODUCTS AND SERVICES}

D What products and services will your company be providing?

D What type of work will you be doing: research, development, marketing, manufacturing, distribution?

(2) FINANCIAL GOALS

D What are your financial goals for five years from now?

D What will your company's (SBUs) revenue stream look like?

- What will your profit margin be?

(3) MARKET GOALS

D Who will your customers be?

- What geographic location will you serve?

- What percentage of market share will you possess?

- How big a player will your firm be in its defined market niche?

(4) IMAGE

D How will your organization be viewed by others?

- What will differentiate your firm from other companies?

(5) WHAT WILL YOU LOOK LIKE IN THE FUTURE?

D How large do you want to become?

- Where will your business be located?

\section{Have I answered this question adequately?}

Result: Your goal is to produce a thoughtful, two-to-three-page document. It doesn't need to be eloquent, but it does need to capture your vision for the future. Put the materials in a three-ring notebook and/or in a computer file. When you develop a commercialization strategy or sales and marketing objectives, check to see whether or 
not it coincides with your vision. Let your vision propel you forward, rather than tie you to the present situation.

The most important elements of the vision are items 1-3. Items 4 and 5 are secondary items to consider when mapping a path for the future.

\section{WORKSHEET: ACTIVITY 3: VISION}

DATE I

INSTRUCTIONS: Your vision for the future is a key element of what propels a company forward. Use the list of prompts on the previous page as discussion points for an off-site or after hours planning session. Your vision for the future must be one you have the energy and drive to pursue. For planning purposes, select a five-year horizon and summarize your conclusions below. Add additional pages as needed.

\section{(1) PRODUCTS AND SERVICES:}

(2) FINANCIAL GOALS:

(3) MARKET GOALS:

(4) IMAGE: 


\section{Mission Statement}

Being able to describe your business in a very succinct fashion is a selling tool. Any manager should be able to clearly and simply express the essence of the business in one sentence. In addition to serving as a selling tool, a clear recognition of your company's mission helps define the commercialization strategies best suited for your firm.

\section{Activities and background:}

A good mission statement should answer the following questions:

D What business are you in? This question is answered by indicating the types of business functions your company performs, i.e., research and development, engineering, manufacturing, marketing, custom design, distribution.

Dhat products and technologies are involved?

D What markets do you serve?

Dhat is unique about your company? What differentiates it from others?

\section{Have I answered this question adequately?}

Process: Start by addressing the preceding questions. Be thorough and don't be concerned about length or style. Once you have addressed all of these issues, try expressing your mission in a 50-word statement. It will probably sound extremely dense. However, adding the word "limit" afterwards forces you to single out the critical elements. The resulting mission statement must pass "The Elevator Test;" i.e., you should be to be able to tell someone what your company does as the elevator moves between floors.

Results: Your goal is a pithy statement describing your company's mission. The following is a good example:

"Voltec Inc. designs, manufactures, and markets the only U/L-approved, high efficiency, computer-controlled power combustion gas fired boilers and heaters to the Real Estate, Education, Health Care and Service sections of the HVAC market in the commercial and industrial segments."

Although this statement is very dense, it contains all the required elements. One instantly knows what business functions the company performs-it designs, manufactures, and markets. One knows what products the company produces-gas fired-boilers and heaters. The listener knows what gives the company a sustainable competitive advantage-it has the only U/L-approved, high efficiency computer controlled device — and what markets it serves - the heating, ventilation and air conditioning market as it pertains to real estate, education, and health care. It would pass the elevator test. 


\section{WORKSHEET: ACTIVITY 4: MISSION}

DATE I

INSTRUCTIONS: Listed below are the four key elements of a good mission statement. Carefully consider each of these and then create a succinct statement. Begin by writing a sentence for each of the following prompts, and then combine them.

Business Functions:

Products/ Technologies:

Markets:

Differentiators:

Succinct Mission Statement 
Cooper, Robert. Winning with New Products. Reading, MA: Addison-Wesley, 1993

\section{Strategic Allies}

If the strategic ally or licensee to whom you entrust the future of your technology/product is not selected with care, your product could fail. Building on the recommendations of Robert Cooper, look for licensees or other strategic allies with whom there is market and/or technology synergy.

\section{Background}

In order to locate a potential strategic ally, it is vital to know and address the ally's needs. This is your responsibility, not the ally's, since you are doing the courting. In other words, when approaching potential strategic allies, your objective is to determine how you can enhance their business, NOT how they can enhance yours. By having your priorities in this order, both businesses will prosper. Suppliers of technology must be able to reduce their allies' (customers') costs or expand their revenues and earnings. Customers (allies) must help suppliers control the costs of selling and serving them. Making the customers a part of the process and sharing more information with them does this. One work that is particularly useful in setting the stage for such collaboration is entitled Growth Partnering: How to Build Your Company's Profits by Building Customer Profits, by Mack Hanan (1992).

The fundamental premise of Hanan's work is that successful partnerships are those in which you as a supplier can clearly demonstrate how you can help build your customer's profits. As a result of this focus and careful attention to laying the ground rules for successful collaboration, your firm will also profit. Hanan's book is filled with examples of how Boeing, Xerox, Toyota, and many other large companies have adopted this approach for mutual benefit. In order for such a relationship to work, there must be mutual objectives, mutual rewards, and mutual sharing of risk.

What this means is that you need to gather detailed information regarding potential allies, and determine whether there is the basis for a partnership. Do you have something to offer a particular customer that results in significant cost reductions or significant revenue enhancement? Of course you can't address this issue unless you know your potential allies well.

Hanan identifies many potential benefits from a large company can accrue from teaming with a small firm. These include:

D obtaining a source of new technology and products to supplement core technologies

D developing the ability to extend or round off current lines to markets

- gaining access to specialized market niches

- gaining new insights about the industry/business

- discovering a new training ground for entrepreneurial managers

- adding specialized application skills

D obtaining a high return on investment 
In all cases, to sell these potential benefits, you need to know the large company's business and look at yours in a different way.

\section{Activities}

In order to find a good ally:

(1) define the appropriate domain of potential allies and/or licensees based on the following:

D needs addressed

D technology synergy

- market synergy

(2) request copies of annual reports and SEC documents if publicly traded

(3) obtain lists of patents and see if they are working in this area

(4) find articles which show what they are doing relative to divestiture, acquisition, new product introductions, change in management, downsizing, and bankruptcy

(5) obtain product catalogues and pricing information.

\section{Have I answered this question adequately?}

Process: Start by developing good intelligence files on potential strategic allies, reviewing the materials, and completing a partnerability analysis.

Result: The purpose of this exercise is to help clarify to whom your product/service can be of greatest advantage. Your goal is to prepare a partnerability analysis using the materials gathered. Develop a matrix - with potential allies listed down the ordinate and with three columns using the following headings: (1) contribution to cost reduction/ revenue enhancement, (2) time frame, and (3) partnering strategy. Complete this matrix to summarize the relative contribution that you could make to the strategic allies you are considering. 


\section{WORKSHEET: ACTIVITY 5: STRATEGIC ALLIES}

DATE

\section{I}

INSTRUCTIONS: Begin this activity once you have developed good intelligence files on potential strategic allies.

Then use the space below to clarify the nature of the synergy between your technology and their needs, technology, and/or marketing and sales capabilities. Add additional pages for each potential ally.

POTENTIAL ALLY NAME

Evidence of strategic fit:

Evidence of technology synergy:

Evidence of synergy with marketing/ sales capability:

Evidence of corporate stability: 


\section{Commercialization Strategy}

The commercialization strategy depends upon the vision and mission of your company. It includes an acknowledgment of the business functions that your company will perform and the financing strategies that you will use to realize your goals. For example, if the business function your company performs is limited to research and development, you might choose to bring the product to market through a licensing strategy. Possible financing strategies that you entertain could include:

- Development funds and licensing

D Small commitment of development funds and first right of refusal on licensing option

In other words, you would be looking to finance the latter stages of development and product introduction by finding a potential licensee who would be willing to fund and execute the following stages. Please note that those who entertain a licensing strategy must pay keen attention to all issues related to intellectual property protection.

By contrast, if your mission also includes manufacturing, then it would be reasonable to entertain one or more of the following.

- Debt financing

D Equity investment in parent company

- Equity investment in spin-off

D Joint ventures

- IPO (Initial Public Offering)

D Strategic alliances-marketing and distribution

\section{Activities and background:}

A commercialization strategy is an expression of the important milestones involved with moving a product from concept to product launch, accompanied by a proposed financing method for each. In preparing this statement, you might find it useful to think about the list of steps presented by Cooper (1993). Next to each activity, indicate how you would fund it. For example:

\section{(1) Initial Screening}

(2) Preliminary market assessment
(1) Bid and Proposal line of General and Administrative ( $G$ and $A$ ) funds

(2) Sweat equity 
(3) Preliminary technical assessment

(4) Detailed market assessment

(5) Predevelopment business/financial analysis

(6) Technology/product development

(7) In-house product tests

(8) Customer product tests

(9) Trial sell

(10) Trial production

(11) Pre-commercialization business analysis

(12) Production start-up

(13) Market launch
(3) Phase I Small Business Innovation Research grant (SBIR)

(4) Retained earnings

(5) Retained earnings

(6) ATP funding

(7) Corporate partner

(8) Beta test at prime partner site

(9) License to distribution partner

(10) Equity financing from angels

(11) Corporate partner

(12) Obtain equity capital

(13) Equity financing

Please note that the milestones listed in the left-hand column come from Robert Cooper's work. This list is illustrative. Different steps will be appropriate for you depending upon the nature of your opportunity. For example, opportunities related to the pharmaceutical industry are likely to include such milestones as human trials and FDA approval. 


\section{WORKSHEET: ACTIVITY 6: COM MERCIALIZATION STRATEGY}

DATE

INSTRUCTIONS: This is a summary sheet on which to map out factors that affect your strategy, as well as the preferred financing steps to utilize to fund each of the activities associated with bringing your product to market.

MISSION STATEMENT:

Business functions:

Target market(s):

Sustainable competitive advantage:

VISION: Select the descriptor that best fits your vision.

BUSINESS PHILOSOPHY:

PRODUCT OR TECHNOLOGY DESCRIPTION:

STAGE OF DEVELOPMENT: 
COM MERCIALIZATION STRATEGY

STEPS

FINANCING METHOD

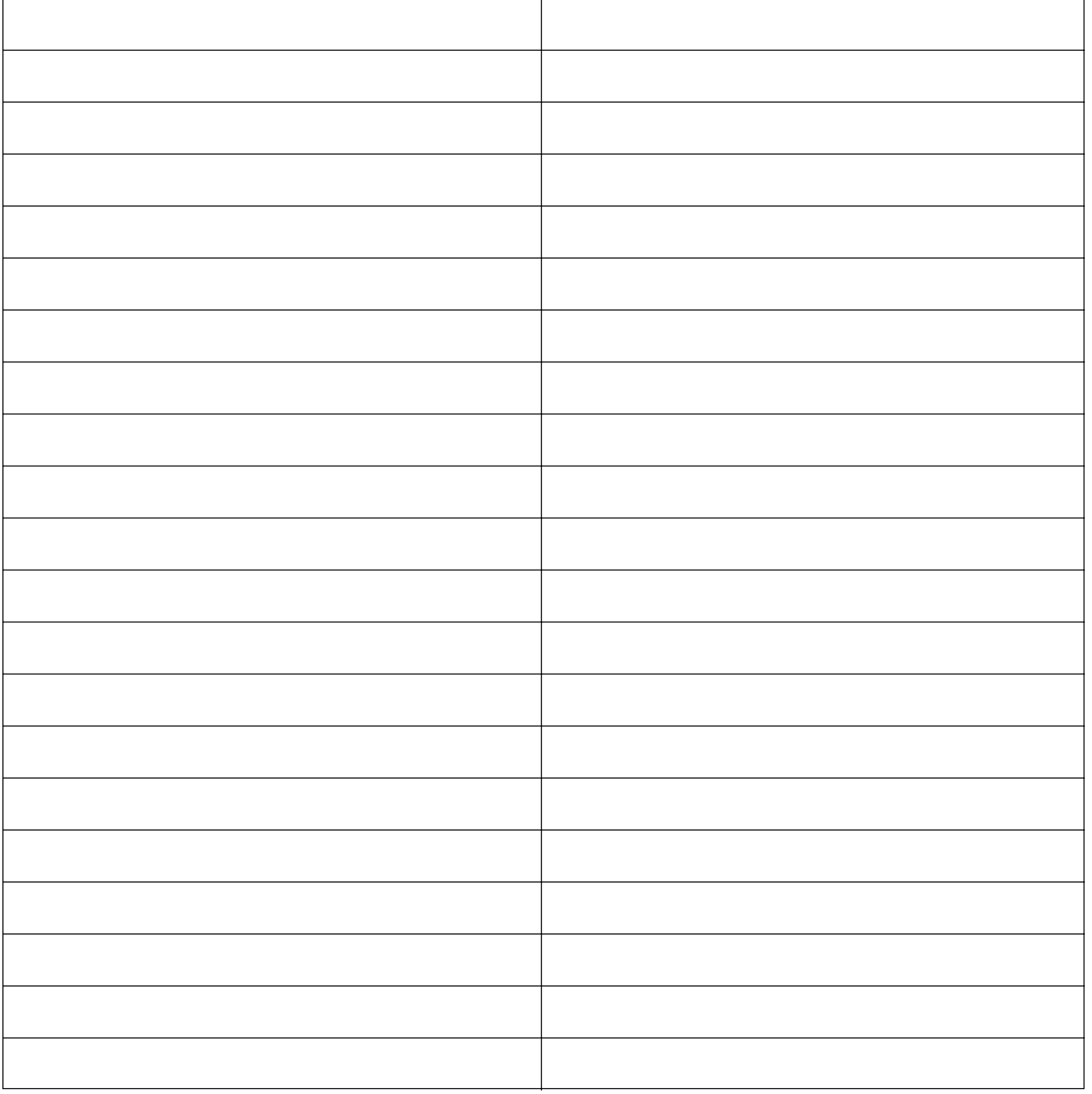


Related Activities:

Activity 7:

Features, Advances, Benefits

(FABs)

Activity 8:

Contacting Potential Customers

Activity 9:

Buying Decisions 


\section{CUSTOMERS AND END-USERS}

$\mathrm{t}$ is important to have direct interaction with potential customers and end-users

throughout the product development process. Such interaction helps verify where potential interest lies, which in turn affects the strategic decisions you make and lays the foundation for conducting a market assessment. The activities in this area of the Workbook (Activities 7 - 9) are intended to help management identify potential customers and end-users and distinguish between them, as well as to identify customer needs and benefits.

Rather than assigning this task to consultants or junior members of your staff, reserve interaction with potential customers for yourself. It is important that you not only hear what potential customers and end-users say, but also that you gauge their degree of enthusiasm and concern.

Customer feedback should also be used to shape your analysis of potential licensees and/or partners. This information will be important in completing your strategic planning process.

\section{Background}

Nothing replaces talking with potential end-users and customers. This is vital to successful commercialization and critical to determining a customer's genuine level of interest in what you have to offer. Early contact also helps you determine if your potential customers have the means to purchase your product. If a company thinks that your product is the greatest thing since sliced bread but doesn't have the funds to purchase it, the company's interest in your product is of little value. The activities in this section are all aimed at helping technologists prepare to talk with potential customers, end-users, and industry experts. Samples are included throughout.

Customers and end-users are often mentioned in the same breath, often leading entrepreneurs to the faulty conclusion that these are synonymous. They are not. An end-user is the entity that utilizes the item produced. A customer is the party which purchases it. The major difference then between customers and end-users is purchasing power. Customers make the purchasing decision, but end-users may not. If you reflect upon this for a moment, it soon becomes apparent that there is often a chain of customers between you and the ultimate end-user. It is also true that on occasion a customer may also be an end-user.

End-user needs are important because they influence purchase decisions. 


\section{Example 1: MRI Components}

Assume that your firm manufactures a component for a magnetic resonance imaging machine (MRI) and that you are contemplating who is your customer and who is the end-user. It becomes apparent that hospital technicians who use the MRI are the end-users. How easy or difficult it is for the technicians to use the MRI is important, and affects the quality of the images produced. However, technicians do not make the decision to purchase the MRI. A board of hospital administrators and/or doctors most likely makes the decision. The hospital administrators are customers, but not your customers. Indeed, if you are the manufacturer of an MRI component, your customer is the system integrator who makes the decision to purchase your component. You need to understand your immediate potential customers, i.e., the frequency with which they purchase these components, what issues are important to them, price sensitivities, and the features, advantages, and benefits they seek. The ultimate customers in the chain (hospital administrators) are also important in understanding market size and the derived demand for this component. Problems the technicians have in using the MRI affect the decision makers at the hospital level. It quickly becomes apparent that understanding the needs and concerns of the entire customer chain is important.

\section{Example 2: Software for Disabled Children}

Assume that you design software for disabled children. The end-users are clearly the children. However, those with purchasing power are parents, teachers, and librarians. It is unlikely that children will directly purchase the software.

Nevertheless, the children certainly influence the decision makers. If your commercialization strategy is to license to a software publisher, then your immediate customer is the publisher, not the parent, who likely will purchase the software from a re-seller. In order to understand the size of the market opportunity, you must examine the chain of customers and end-users that exist between you and the end of the chain. Understanding the needs and limitations of the end-users affects software design; understanding the purchasing behavior of the ultimate customer effects your understanding of market size and growth; and understanding the needs of your immediate customer allows you to position what you have relative to his needs.

Both customers and end-users are important. As you will discover in the next section, if no qualified customers exist, then you have no market, no matter how great the need. A qualified customer is one with money, access, and desire. The acronym MAD is sometimes used as shorthand to describe qualified customers. Your goal is to find customers who have Money, Access, and Desire. This customer is determined by need and the ability of what you offer to address that need. Access is determined by the channels that you use for sales and distribution. 
Money must exist in order for the interested party to qualify as a customer of interest to you. This point cannot be underestimated. Often entrepreneurs are blinded by the issue of need and confuse need with purchasing power-but these are two separate issues. You must first qualify potential customers on the basis of need and money, and then design your marketing and sales plan to maximize access.

\section{Example 3: Exporting Rice}

Let's assume that you grow rice and are looking to export to an overseas market. You know that thousands of individuals die each year from famine. Clearly there is a need for your agricultural product. However, the starving masses have no purchasing power. They are end-users, but, lacking the money to purchase what you have, they are not customers. If no relief organization steps forward to purchase the food on their behalf, no customers exist. Without qualified customers, no market exists, even though there is a need. However, if CARE or another relief organization steps forward to purchase the rice, a market is born. An absurd example? Not really.

Technologists frequently confound the need of end-users with market potential. A classic example involves the cleanup of U.S. nuclear sites. Economists study the problem and conclude that it will cost somewhere between $\$ 200$ billion and $\$ 1$ trillion to clean up these sites. As with the previous example (rice), there is clearly a need. However, if the federal government does not provide the funds to clean up the sites, there is no market in the same fashion that there was no market for selling rice to famine-ridden countries without qualified customers. End-users AND potential customers are important, but qualified customers that are MAD are vital!

\section{Objectives, Method, and Questions}

Many technology-driven companies fail to talk to potential customers early in the technology/product development process. The tendency is to assume that many customers will want the technology and that the technology or product addresses a real need. The ultimate survival of your business depends upon the purchases made by customers, and it is vital to ask the customer what he wants early in the development process. For the technology-driven company, the customer must quickly shift from being a hypothetical construct to a tangible entity. The earlier you begin discussions with potential customers, the quicker you can begin to articulate customer specifications and save development time and dollars. 
There are many methods you can use to collect information from potential customers, end-users, and industry experts. You should ultimately use a method that fits with your planned activities and style. For example, if you plan to attend a trade show, you could develop a survey form and ask people to complete it. If you are traveling, you might collect anecdotal, in-depth information through person to person interviews. Other alternatives include phone interviews and mailed surveys. Whichever method you use to gather information, you must always begin by clarifying your objectives.

\section{Objectives}

Prepare for talking with potential customers and end-users by clarifying your objectives. For example, if your objective is to determine features that affect a purchase decision, you might ask:

D When buying a solution to Problem Y, what features do you look for?

D When comparing similar products, what do you compare?

D What are the key criteria you consider when deciding to purchase a solution for problem Y?

D How frequently do you purchase X?

Dhat is the average price range of solutions that you entertain?

D Who is involved in the decision to purchase X?

\section{Method}

The next decisions are how to gather the information needed and how large a sample is needed. As was mentioned earlier, face-to-face interviews can be conducted at trade shows, conferences, and meetings scheduled for the purpose of exploring these issues. Telephone interviews can be initiated by a letter advising that you will call to discuss XYZ or with a "cold" call. In-depth interviews allow you to branch and explore a range of issues based on the information that surfaces during the interview process. Once you have determined your objectives, generate questions that are intended to surface answers addressing your objectives, and then select a sample to contact.

Listed below are some questions that we generated before contacting industry experts. Our objective was to gather some useful data points that we could use in sizing the market for a power cogeneration device. We decided to interview industry experts instead of customers and end-users because it was most time efficient. You might also consider this as a strategy for gathering information. 


\section{Questions}

Objective: To determine how many potential end-users there are in the U.S. for a cogeneration device in rural residences and remote works-sites.

(1) How many rural residences are there in the U.S. which have inadequate electricity (inadequate $=$ can't get it there or too expensive to do so)?

(a) What subset of these are in areas which have plenty of biomass (wood or agricultural waste)?

(b) How much electricity do they need?

(c) What is their reaction to the utility of co-generation from biomass and the generator output they would require?

(d) Do they keep data on recreational cabins and hunters' lodges in the outback? (Ask the same questions a through c)

(2) Paper Industry-How do they define a remote work site?

(a) How many remote work-sites are there?

(b) Would they have use for the cogeneration device?

(c) How much energy would be required to drive $\mathrm{X}, \mathrm{Y}$, and $\mathrm{Z}$ ?

(d) Are there tax or regulatory-driven incentives for getting rid of the waste that would fuel this cogeneration device?

(3) Forestry-How many outposts are there? How many cabins in parks?

(a) What subset of these are in areas which have plenty of biomass (wood and agricultural waste)?

(b) How much electricity do they need?

(c) What is their reaction to utility of co-generation from biomass and the generator output they would require?

\section{Finding Industry Experts}

Generating a list of industry experts can be accomplished in a two-to-three-hour period, using a handful of reference materials available in any public library; for example:

- Encyclopedia of Associations

- Gales Directory of Publications and Broadcast Media

D U.S. Industrial Outlook 


\section{Sample Interviews}

Once you have developed your objectives, questions, and contact list, the next task is to conduct the interviews. In all cases you should view the interviews as datagathering. This is not a sales call, although the contacts may prove to be very useful in a wide variety of ways. Data gathering is something that all scientists and engineers do; the only difference in this situation is that you are collecting information from other people.

It is useful during the interviews to take good notes. Be sure to reference interviews with industry experts in your business plan and other documents that you generate regarding commercial potential. Listed below are samples of data collected in a few interviews with industry experts. The purpose for including this interview is merely to demonstrate the amount of information that can be obtained from well-structured phone interviews. The information gathered provided useful data points that could then be used in sizing a potential market.

\section{Interview \#1: Association}

1. Logging in the industry is becoming more decentralized, with small contract logging firms filling the predominant role over the paper companies. There are far fewer company-owned centralized logging camps in harvesting sites that are without electric power.

2. While the lumber and paper industries (primarily paper) are incredibly energy intensive, using $12 \%$ of all industrial energy, amounting to $2.5-3$ quads, or $3 \%$ of total U.S. energy consumption, the harvesting site uses little electricity.

\section{Interview \#2: Association}

1. There are few remote facilities. Larger independent contract harvesters predominate over smaller players, and they tend to centralize their facilities in locations with access to power.

2. You might have an application involving powering very small sawmills, 1- to 2-man operations, which cut a customer's trees to build his log cabin.

3. As a result of environmental efforts, there is a lot more emphasis on leaving the waste in place. Downed logs provide homes for bugs and a habitat for small animals, which are food for raptors.

4. An exception may be large areas of dead wood, from beetle kill, for example. It is possible that small trail crews and ranger districts in these areas may have use for small-scale remote generated electric power. Mr. ABC, the new head of the Forest Service, is from Eastern Idaho, where there has been a lot of beetle kill. Discussed biomass utilization at the last industry round-table. 


\section{Interview \#3: Association}

1. Most remote work sites don't have a need for electricity.

2. You could use your device to turn chipping and debarking devices that require high torque.

3. There is no need for lighting at the remote sites.

4. I suggest you put together a focus group of loggers and put the issue to them.

What you offer is radical and different from present thinking. It might have strong potential, but requires use in ways that are different and not readily apparent.

5. You might have an application in a small portable sawmill, but you might be too small in power.

\section{Interview \#4: Editor of a trade journal}

1. Our readership is 31,000 .

2. I think XYZ technology is a heck of an interesting idea. We put on tech conferences around the world, including Europe.

3. I see applications for the technology in Europe and developing nations.

4. There are a tremendous number of emergency loads that require just a fraction of the power of a household, such as for telecommunications equipment.

5. It is important to realize that there are entire sections of the U.S. where wood burning is an anathema. Creosote from wood stoves is a highly carcinogenic. Many ski areas in Colorado and Vermont restrict wood burning, with or without a catalyzer. This air pollution can be a problem any place, particularly in valleys with a lot of wood fires. In many of these areas, there are quite a few times a year when burning of biomass is restricted.

6. This is not a problem outside the U.S. I see thousands of site applications for your device in the Western Hemisphere.

7. Canada is more spread out; you can do anything you want there. Canada also allows government bodies to subsidize emergency power. This can work to keep people in areas or open up new areas for settlement.

8. It might be worthwhile to explore U.S. Government funding for the application of your device for disaster avoidance and recovery. I don't know where the funds are, but they're there. 


\section{Features / Advantages/ Benefits}

Customers use different criteria in making their purchasing decisions. Sometimes the decision is based on price and at other times on the features, advantages, and benefits of the product. It is, therefore, important to know how your technology/product compares with competing products and services that are available.

- A Feature is an element or property of the product or technology.

D An Advantage answers the question "So what?" and indicates the value of this feature. The advantage is frequently described in technical terms and tends to describe the competitive advantage from the company's perspective.

D A Benefit describes the value to the end-user as he or she would perceive it.

\section{Have I answered this question adequately?}

Result: The goal is a completed Feature/Advantage/Benefit (FAB) matrix for your company, listing at least five features for each technology/product. There should be a corresponding advantage and benefit for each feature. 


\section{WORKSHEET: ACTIVITY 7: FEATURES, ADVANTAGES. BENEFITS (FAB)}

DATE I.

INSTRUCTIONS: Prior to beginning the process of contacting potential customers, end-users, or industry experts, it is recommended that you spend time reflecting upon the features, advantages, and benefits of your technology, product, or service. Part of the interviewing process should include questions designed to surface whether or not these FABs are important to potential customers and at what price. 
"The relationship between the man and the customer, their mutual trust, the importance of reputation, the idea of putting the customer first-always. All of these things, if carried out with real conviction by the company, can make a great deal of difference in its destiny."

Thomas Watson, $J r_{\text {., }}$ Chairman, IBM Corporation

The 1962 McKinsey

Lectures, Graduate School of Business, Columbia

University

\section{Contacting Potential Customers}

\section{Activities and background}

For each market you are targeting, interview at least five potential customers or industry experts to determine their needs relative to your technology/product.

\section{Process:}

1. Decide upon your objectives for this outreach initiative and generate questions that will enable you to gather relevant information.

2. Carefully select the potential customers or industry experts you will approach by:

D Determining which companies to approach

- Developing a contact list within those organizations by looking for names in trade journals, trade associations, conference proceedings, Standard and Poor's register, local newspaper articles, and/or from conversations with the public relations department of the organization in question

3. Before making the initial contact, decide what information about your company and research you are at liberty to discuss, given the degree of intellectual property protection you want to maintain for your technology. Keep in mind this is a data-gathering activity, so the focus is not on your technology-but rather on the need addressed. However, the opportunity might arise to share some information regarding your technology/product and you need to determine in advance how much non-confidential information you will share.

\section{Have I answered this question adequately?}

Result: Your goal is a complete set of written notes from the interviews. The number of people to be interviewed depends upon the financial decisions to be made based upon these data. Interaction with potential customers is iterative. The numbers of people included in initial interviews may be quite limited (five to ten people). However, subsequently larger samples will be required. 


\section{WORKSHEET: ACTIVITY 8:}

CONTACTING ENDUSERS, CUSTOMERS, AND INDUSTRY EXPERTS

DATE I I.

INSTRUCTIONS: Use this section to clarify the process that you will use to gather information.

(1) OBJECTIVES:

(2) GROUP TO APPROACH:
Customers
End-users
Industry Experts
Other (name)

Rationale for selection of group:

Sample size with rationale:

How to locate:

Who will collect information?

METHOD FOR GATHERING INFORMATION:

Paper and pencil tasks: $\square$ mailed survey $\square$ survey distributed at trade show/conference

Interviews $\square$ telephone interviews $\square$ interviews at trade shows/conferences/others

QUESTIONS TO BE ASKED: (Be sure that the questions relate to the objectives.)

Information that you ARE willing to share about your company/ technology/ product?

Information that should NOT be discussed.

Courtesy to be extended to interviewees: After conducting an interview, it is appropriate to send a thank-you note. If you are collecting information at a conference, you might hand out a token item of appreciation such as a pen, small calculator, etc. 


\section{Buying Decisions}

Your company's cash flow depends upon your potential customers' buying behavior. There may be times during the year when customers are more likely to make purchase decisions than others. This will affect your models for predicting revenue. It is very common for new organizations to give inappropriate consideration to the sell cycle of potential customers and to how the customers' buying decisions are made. However, one quickly learns that adequate cash flow is what keeps a company going.

\section{Activities and background}

Previously, you identified the potential customers for the various applications under consideration. For each application, list the customers and what you know about their buying behavior.

\section{Have I answered this question adequately?}

Process: Do you have good solid data about each potential customer? The following is an example of one customer's process. Company $\mathrm{X}$ makes decisions by committee. However, the process begins with a meeting with Mr. John Doe, who acts as the first level screen. Mr. Doe is very hard to reach by phone or in person. It takes about a month to set up an initial meeting. The committee meets every two weeks, but it takes about two months for new items to appear on the docket. Once the decision is made to buy, processing the paper work takes approximately another two months. The decision to buy is very much affected by referrals, the state of the art, and your prestige. After you begin working for Company X, the payments are made within 90 to 120 days, even though terms are indicated as 30 days. This information was gathered through a conversation with another vendor who has worked with this company for over five years.

Results: The goal is a list of the customers (at least at the company level), who makes the decisions, how long the sell cycle takes, and what types of considerations affect the decision to buy. Indicate your data source for each customer. 


\section{WORKSHEET: ACTIVITY 9: BUYER BEHAVIOR}

DATE I _-_-_-_-_-_-_ I --_-_-_-_--_-_-_

INSTRUCTIONS: Use this activity as a prompt, to determine if you truly understand the buying behavior of your targeted customers. Often, this type of information is gathered in the execution of the previous activity. Add additional pages as required.

\section{Customer type}

Decision-maker:

Sell cycle:

Basis for purchase decision:

Other considerations/observations:

How information gathered:

\section{Customer type}

Decision-maker:

Sell cycle:

Basis for purchase decision:

Other considerations/observations:

How information gathered:

\section{Customer type}

Decision-maker:

Sell cycle:

Basis for purchase decision:

Other considerations/observations:

How information gathered:

\section{Customer type}

Decision-maker:

Sell cycle:

Basis for purchase decision:

Other considerations/observations:

How information gathered: 
Related Activities:

Activity 10:

Market Segmentation

Activity 11:

Market Size

Activity 12:

Market Growth 
The activities in this area of the Workbook (Activities 10 - 12) are designed to

lend greater specificity to your understanding of the markets pursued. You are encouraged to turn to other sources to help gather the information needed to build a hypothetical construct of market size. Once this information has been gathered, include it in items such as your business plan or licensing package.

\section{Background}

In this section, we move to a discussion of markets and present a way of aggregating information about customers. Various dimensions of the market either contribute heavily to or detract from the commercial potential of the opportunity at hand.

During the past 30 years there has been a steady migration away from the concept of mass market and toward the concept of niche markets (Webster, 1994). With mass markets, the premise was that one should produce product in large quantities to achieve economies of scale and to provide the mass-produced product to the greatest number of customers. Most customers received a little of what they wanted, and few were totally satisfied. By comparison, the concept of "niche market" focuses on customization and meeting very specific needs of customers.

The shift, then, is away from generic products and toward customer-defined products. The task every company faces is to determine which market niche(s) it will serve. Companies grow their business by focusing on customers and then stepping from one niche to another. Furthermore, "Customer choice shapes the business, which is why customer choice is such a critical strategic decision" (Webster, 1994, p. 96).

Earlier, we spoke about a chain of customers, starting with the entity which purchases directly from you and ending with the customer which makes the ultimate purchase decision. The first question to address is which level of customer do we focus on when sizing the market?

To shed some light on this question, let's begin by differentiating between consumer and industrial markets (Sandhusen, 1987). Industrial markets consist of all individuals and organizations that acquire good and services used in the production of other products and services supplied to the ultimate customer. 
Industrial markets share a number of characteristics.

(1) There are fewer buyers than in the consumer market. For example, if you make a component that can be used in automobiles, there are but a handful of potential direct customers among major automobile manufacturers or automotive assembly manufacturers.

(2) The buyers are larger. The quantity of items that a customer such as Boeing or Motorola might buy could be sizable, i.e., hundreds of thousands of units, versus dozens.

(3) There is a geographical concentration of industrial buyers, with $50 \%$ in 10 states.

(4) Demand is derived from the purchasing behavior of other customers in the chain. This is an important point in sizing markets, as you need to size the market from which your immediate customer's need is derived.

(5) Demand is inelastic, which means that short-term price changes don't produce disproportionate demand changes.

(6) The demand is more volatile. This means that small changes in consumer demand can result in large changes in industrial demand.

(7) There are professionals involved with purchasing function.

With respect to industrial customer buying behavior, there are three major types of buying situations: (1) a straight rebuy, (2) a modified rebuy, and (3) new tasks. The latter is the arena in which most new technology firms will find their opportunities. A number of decision-makers are involved in such purchase decisions; therefore, it is important to interact with the variety of people that influence such purchase decisions. These include the users of the technology/product, the influencers (such as design engineers, regulators, and the like) and the decision-makers. Factors which are known to affect the ultimate buying decision include product specifications, price, terms and delivery times, service terms, order quantities, payment terms, and whether the suppliers are approved.

If you have a component you wish to license, sell, or distribute to an industrial customer, it is important to understand not only who is involved in the decision-making process, but also what issues are of importance to them. As their demand for what you have will be derived from other customers and end-users in the chain, you will need to size the market as it pertains to the ultimate customer at the end of the chain. In other words, let's assume that you are looking to sell an MRI component to a company in the manufacturing sector, and you are trying to assess the size of the market opportunity for you. In this case, you will size the market based on the ultimate customer in the chain (the hospital administrators). Likewise, if you sell a software tool that can be used to interface more effectively with the internet, you would size the market opportunity based on the ultimate customer in the chain, i.e., the individuals who make the decision to purchase the software for themselves or their organization. If you sell a device that can be used in clean up of nuclear sites, you size the market based on the ultimate 
customer in the chain that makes the decision to purchase the technology to be used in the clean up.

\section{Sizing Emerging Markets}

Commercial potential increases if one is dealing with emerging or imperfect markets. An emerging market is one which is ready to go through rapid growth in terms of market size; whereas an imperfect market is a pocket of unmet need (niche) within a mature market. Most of you are dealing with emerging markets. One of the dilemmas you will face is estimating your market's size. Since the market is about to grow, but has not yet grown, how can you size the opportunity? Most technologists, not understanding how to proceed, merely use the most easily defined market and most readily available industry figures and say, "This is the market size." This is NOT the approach to take, and immediately betrays to a potential investor or ally that you don't understand what you are doing.

Approaching the issue of market size in this fashion often leads to failure because it does not help you understand either the size or the composition of the market niche with sufficient clarity to be able to develop good operational plans for success.

In this section, we will develop an example showing you how to size an emerging market using a market build-up method. Before beginning, though, let's define a related set of concepts: market, potential market, available market, served available market, penetrated market, and total market demand.

A market is a set of actual and potential buyers. Information about the potential buyer is vital to sizing an emerging market and using the market build-up method.

A potential market is a set of actual and potential buyers who have money and desire to purchase a product with a specific set of price and performance characteristics. Note the relationship between this and the definition of qualified customer.

The concept of available market adds one more descriptor to this definition-access. Access is determined by your marketing communication plan. If there are plenty of fish in pond $\mathrm{X}$, but you fish in dead Pond $\mathrm{Y}$, your catch will be nonexistent, not because there are no fish, but because you have limited access. An available market is a set of actual and potential buyers that have money, desire, and access. It is the set of actual and potential MAD customers.

As indicated by Reis and Trout (1986), "The essence of positioning is sacrifice. You must be willing to give up something in order to establish that unique position." One of the most difficult things for companies with a rich technology base to do is focus. Technologists tend to be overwhelmed by and sometimes enamored with the possibilities of their technology, and they feel that, by focusing, something will be missed. However, it is important to keep in mind that a niche marketing approach is a sequential process, not a permanently exclusionary one. 
The focusing approach leads to better use of resources and greater success. "Just because there are a lot of targets and you've got a lot of shot, doesn't mean that you don't have to take aim" (Linneman and Stanton, 1991, p. 7).

The concept of penetrated market is different in kind and relates to the extent that you and others have addressed the opportunity.

Total market demand is an expression of the volume that could be purchased by a specified group of real and hypothetical customers within a defined period of time under certain conditions.

If the relationship between these markets is visually represented, you will see the size of the market niche is winnowed down to a more tightly defined and smaller niche. It is represented in dollars or units, on an annualized or total basis. However, annualized figures need to be based on verified data or known trends in that market, rather than as a straight average of the total market demand.

In summary, commercial potential increases with a niche marketing approach if the total market size is above a certain threshold ( $\$ 100$ million or more is a common minimum). You should be cautioned that statements such as "The market is multibillion" make it apparent that you are not using a niche marketing approach. Furthermore, to say that the market is "unknown" betrays that you have not tried to assess the market potential. By contrast, if you have rigorously examined the market potential and it appears that the total market demand is less than a $\$ 10$ million opportunity, it will be of little interest to most investors and should lead you to re-evaluate the market you are addressing, as well as serve as a catalyst to reexamine the product definition.

\section{Market Segmentation}

The process of deciding which market niche(s) to pursue begins with market segmentation. This is a highly dynamic process in which both the features of the product as presently conceptualized and the characteristics of the ultimate buyers are used. The goal is to conceptually define homogeneous groups based on the parameter(s) that you select. The result should be a niche which is substantial in size and can effectively be reached with a designated marketing communications plan.

Segmenting the market appropriately is an art and takes considerable time and effort. Common ways of segmenting market include the following:

- Benefits sought

- Buyer readiness stage

- Customer size

- Geography

- Usage rate

D Price

D Type of customer 
Based on the earlier interaction with potential customers, one begins to segment the market in ways that reflect key features of the interaction; i.e., was price important to the potential customers, and is there a high-end, low-end, and medium group for which various products might be appropriate? Are the more interested customers early adopters and does it make sense to segment one stage of buyer readiness? One segments the markets in various ways, examining homogeneity within the segment, the ability to cost-effectively reach members of that segment, and relative size.

When you segment a market, each segment should be distinct enough that it requires its own marketing communications plan. If you find that one marketing plan would work well with multiple segments, it would be wise to combine them into one segment.

Segmenting the market appropriately is an art, and takes considerable time and effort. Taylor (1986) provides three questions for helping you decide if you have segmented the market appropriately.

\section{(1) Is the segment definable in some operational way?}

In other words, can you accurately quantify how many customers are in the segment? For example, if you define a market segment by using the following demographic variables (children under five feet tall with freckles), you will probably have difficulty quantifying potential customers in this niche. It is unlikely that you would find any organization sorting data in this fashion, thus making it difficult for me to quantify the size of this market. As a result, this would NOT be a useful segmentation criterion.

\section{(2) Can you reach this segment effectively through affordable advertising?}

Each segment should be distinct enough that it requires a distinct marketing communications plan. If you find that one marketing plan would work well with multiple segments, it would be wise to combine them into one segment. Keep in mind that affordable advertising can include things such as face to face meetings, conferences, and phone calls. Do not assume that advertising means only print copy.

\section{(3) Is it small enough for you to dominate and large enough to provide good profits?}

The most common error that companies make is to define their market too broadly. You should aim at specificity and understanding of the market segment you define. Once you have the segment defined appropriately, develop a strategy for becoming a significant player in that niche. Remember that your ability to obtain significant market share begins with your aspirations and operational plans. 


\section{Have I answered this question adequately?}

Process: Start the segmentation process by looking for commonalities among potential customers. What do they share? Are they all research and development firms? Are they all interested in a specific price range? Are they interested in a specific product characteristic? Are they located in a specific geographic region? Try to be as specific as possible regarding their interests, as expressed to you by these potential customers. Then determine if you can define the market segment in an operational fashion and reach it with cost-effective advertising.

\section{A Market Build-Up Approach: An Example}

There are many methods which can be used to derive the size of emerging markets. The method preferred by Dawnbreaker is referred to as a market buildup method. This method yields a hypothetical construct which defines the size of an available market. The data and assumptions used in building the model are clearly articulated, so that anyone can see the method used to derive market size. One starts with commonly available data points and then collects more difficult information to refine the model. In the example which follows, information from the 1994 Statistical Abstract of the United States was used as the starting point and combined with other information gathered from industry experts by phone and from potential end-users (who were also potential customers) in a mall intercept.

One begins the market build-up method with a product concept. In the example which follows, the product is a "warm suit for stranded motorists," a lightweight piece of outerwear that could be tightly rolled and conveniently stored under one's car seat in a vacuum sealed bag. The concept is that in a cold weather emergency situation, the driver could pull this out, put it on, and remain warm for an extended period of time. The need addressed was protection from the cold in remote areas. It is assumed that the selling price is $\$ 25.95$.

The obvious potential market for this product consists of car owners who live in snowy regions. However, after brainstorming regarding other potential end-users, other market segments were suggested, including sports enthusiasts, military, and workers on oil rigs. In most of these cases, the product definition would need to be refined to serve these markets. In our example, the warm suit was designed for one-time use, due to the need to reduce the volume to fit it back into a small, vacuum-sealed bag. The concept would therefore have to be refined to be applicable to other markets.

The decision was made to size the market for automobile use first. The challenge was to define the available market based on money, access, and desirethe criteria mentioned earlier for qualifying potential customers. 


\section{STEP 1:}

Determine the size of the market, obtain data from the Statistical Abstract of the United States regarding automobile registration, and tally the number of automobiles registered to people in those states that have considerable snowfall.

Result: 67,611,000 motor vehicle registrations.

\section{STEP 2:}

Determine what percentage of this group would have a desire for this product. It would be wrong to conclude that by virtue of owning a car and living in a cold climate that one would have a desire for a warm suit. The premise adopted was that those individuals who carry some sort of emergency gear in their car have demonstrated an interest in protection from the cold, and would therefore be potential customers. Various approaches were used to try to get a handle on the size of this subset, including contacting AAA, various other associations, and editors of journals and catalogs that specialize in emergency situations. Ultimately, the decision was to conduct a mall intercept in a number of cities. In the mall intercept, a table was set up at an exhibit and men and women of driving age were asked if they kept cold weather emergency gear in their car. Ten percent of the sample did. Using this data point, we reduced the size of the potential market from 67,611,000 (the registered vehicles in cold climates) to $10 \%$ of that, or $6,761,100$.

Result: $6,761,000$ were inferred to have a desire for product.

\section{STEP 3:}

Determine what percentage of this group had the money to spend on this product. The Statistical Abstract of the United States includes information on car registration, broken down by age, income, and gender. Given the initial conceptualization of the product - retail price of $\$ 25.95$ - it was assumed that the product would be of greatest interest to those who had an income above $\$ 35,000$, i.e., others would just use a blanket. Forty-five percent of the sample fit into this category.

The figure obtained previously $(6,761,000)$ was further reduced to reflect income. $6,761,000 \times 45 \%=3,042,450$

Result: $3,042,450$ were inferred to have the disposable income to spend. Thus, the potential market size for this niche was 3,042,450 units over the life of the product. 


\section{STEP 4:}

Determine the size of the available market by taking into account access as determined by the marketing communication strategy selected by the company. The firm decided to market this product strictly through catalogs. After talking with industry experts, it was determined that $40 \%$ of the relevant income group make purchases from catalogs. The market size was further reduced to take into account the distribution channel selected. $3,042,450 \times 40 \%=1,216,980$ units.

Result: 1,216,980 people were inferred to have access to this product based on their widespread use of catalogs. Thus, the available market size was 1,216,980 units. Translating this number of units into a dollar value was accomplished by multiplying the total number of potential purchasers by the selling price of $\$ 25.95=$ $\$ 31,580,631$. Realize that the marketer of this product would then need to determine what might be the annual market for the warm suit and any current or potential competing products. The actual market demand in any given year would be substantially less than $\$ 31.5$ million, because that figure would exhaust all current, potential buyers in the current U.S. market.

\section{Conclusion}

The market build-up method uses a combination of reasonable and clearly articulated data and assumptions to determine the size of a market niche. As you can see, the conclusion is as good as the assumptions made, the product definition, pricing, and the marketing communication plan. A different configuration would yield a different result. In all cases, the conclusion drawn needs to be reasonable, defensible, and clear.

A common mistake that would be made by most entrepreneurs-namely, in sizing the market for warm suits, would be to begin and end with finding the number of people that have cars in areas with heavy snow $(67,611,000)$ and falsely conclude that the market size was $\$ 25.95 \times 67,611,000=\$ 1,754,505,450$. The market build-up method requires that the user examine the issues of desire, money, and access, and size the market in light of those factors.

\section{Common Errors}

When sizing markets, a number of common mistakes are made. The most common is to take a dollar value ascribed to an industry and to use that figure to represent the size of your market. 
Example 1: A company that manufactures a sensor quotes the dollar value of the entire instrumentation market as the size of its market. If you manufacture a component that can only be used in one family of instruments, you must conceptually limit your market to the dollar value associated with the use of that component.

Example 2: If you have a device which can be used to remove heavy metals from a waste stream, the size of your market is that subset of actual and hypothetical customers which have the specific problem that you can address. Do not cite the dollar value for the entire environmental remediation market as your market.

Example 3: If you produce a software package on topic X, your market size is limited by the content scope of the software and the customer it targets. Do not cite the dollar value spent in the U.S. on all software as the size of your market.

Example 4: If you have a combustor that can be used with generators of a certain size, your market is limited to generators of a specific size. Do not indicate that the size of your market is equal to the entire power grid of the U.S. times a certain price per kilowatt. 


\section{Market Segmentation}

The process of segmenting your market provides focus for your marketing communications strategies and also serves as a means of obtaining a clearer understanding of your market. An excellent resource to examine in this regard is Competitive Marketing Strategies, by James W. Taylor (1986).

\section{Activities and background:}

Using the form on the next page, indicate which descriptor(s) you will use to segment this market, as well as the rationale for segmenting in that fashion.

\section{Have I answered this question adequately?}

Results: Your goal is to produce a description of the market segment you will pursue. Indicate the approach that you will follow to determine the size of that segment and to locate potential customers. Then, clarify the types of communication vehicles that can be used to reach this segment cost-effectively. 


\section{WORKSHEET: ACTIVITY 10: MARKET SEGMENTATION}

DATE

INSTRUCTIONS: Use this section to help you think through the best way to segment your market.

1. Segmentation criteria: Based on your interaction with potential customers, end-users, and industry experts, indicate the criteria that you will use in segmenting the market, as well as the rationale for segmenting in this fashion.

2. Availability of data in this format? In order for segmentation to be useful, data must be available to support your segments.

3. Does the method of segmentation appear to result in a market segment that you can dominate within five years? At this point, you may not have formally addressed the issue of market size. However, you should have an impression as to whether or not the market is segmented in such a way that you could become familiar enough with the players and the dynamics to become a dominant player. Justify your answer in the space provided below. 


\section{Market Size}

Market size refers to the potential of a market in dollars, units, or in a specific time frame. This concept is applied to the segment(s) for which your product is appropriate. The appropriate segment was determined from analyzing the feedback you obtained from talking to potential customers. Keep in mind that market size is not synonymous with sales projections. Market size represents all possible sales that could be made by all suppliers that can address the need of potential and actual customers.

When sizing the market, it is important to differentiate the difference between the total potential market and the served available market. The served available market defines the market segment or niche in which your company will be operating in more precise terms. This precision enables your company to isolate the market area in which it can aim at becoming a dominant player. By contrast, the total potential market is the larger, related market in which your company is operating. For example, if a company produces heaters, the total market would be the heater market, defined in heater units and accompanying dollar value. However, if the company produces a heater with specific product characteristics, i.e., a small heater that produces $300 \mathrm{BTUs}$, those product characteristics come to define the served available market. In other words, this product competes within a subset of the total potential market. The company's product does not compete with all heaters in the market. The subset defines the served, available market and is the market niche of interest (small heaters producing 300 BTUs). 


\section{Activities and background}

It is often difficult to obtain exact numbers on the size of the market. This problem is amplified if the product is new. The first place to start in trying to determine market size is to contact various sources to see if someone else has already compiled these statistics. Assuming that they have not, proceed with using a market build-up method. However, you may initially find it useful to contact some of the following sources:

Associations: The Encyclopedia of Associations is an extremely valuable resource, found in most libraries. This three-volume set is produced annually and contains an index and two accompanying volumes. There are associations for almost every item imaginable. Every entry provides the name of the association, its services, membership, and a contact person. The association will indicate if it collects statistics. If it does collect statistics, call the contact person and inquire if they cut the data in the manner of interest to you (your segmentation technique).

Regional Technology Transfer Centers (RTTC): Many of the NASA RTTCs will conduct on-line searches for you at reduced rates. Searches are done with key words, using Boolean logic. You could request a search on "market size" of a specific item. Ask for a price and time of delivery quote.

Journalists and Futurists: Another way to obtain information is to contact journalists and futurists that have written articles on the industry in question. When you find a valuable article, contact the editor and ask him to provide you with the phone number of the author. Contact the author and see if he has come across any information on the "market size." 
Findex-The Directory of Market Research Reports, Studies, and Surveys: This resource is found in most large libraries and lists published market research reports. For the most part, the reports are quite expensive. However, if you find the name of a research report of interest, you can contact specialty libraries in your area and see if they have a copy that they will let you see. Corporate libraries are the most likely to have such reports. (Bob Berkman, the author of Find It Fast ((1990)), has various tips for talking with experts and for gaining access to specialty libraries. These are described in his book.)

\section{Have I answered this question adequately?}

Process: Consult the data sources above to try and obtain published estimates on the size of the market. If these data are not available, you will have to infer the size of the market from data you collect on potential customers; for example, information regarding their buying habits and price point. Markets are ideally expressed as annual figures indicating the number of units that might be purchased by the customer base from all sources and the associated dollar value.

Result: The goal is to size the market. Have you defined the following?

(1) The total potential market

(2) The served available market 


\section{WORKSHEET: ACTIVITY 11: MARKET SIZE}

DATE

INSTRUCTIONS: The following is a series of prompts to use in defining the size of a market utilizing a market build-up method.

(1) Based on the interaction you had with potential customers, define the type of individual or organization that should have a need for your technology, product, or service. Assure that your definition contains within it an implicit way of gathering information regarding the number of entities with said characteristic.

(2) What data can you find which indicates the number of entities with that characteristic? Add pages and provide supporting data.

(3) In addition to the data collected, what assumptions have you made which are not supported by data, but are necessary to develop your hypothetical construct?

(4) What is the selling price of your product, technology, or service? On what do you base the assumption that this selling price will be acceptable? 
North American Industry Classification System, United States Department of Commerce, 1997.

\section{Market Growth}

Conditions that affect the rate of growth in a market change. Such conditions include changes in demographics, technology, regulations, and other economic conditions. In predicting the rate of growth in your company's business, it is important to consider the various trends affecting the rate of market growth.

\section{Activities and background}

Industry journals and associations continue to be among the most valuable resources used to detect market trends in advanced technology. The Encyclopedia of Associations, a reference found in most libraries, is commonly used to find the names of many contacts and sources of data.

In seeking market information, one piece of information that will prove useful is the pertinent Standard Industrial Classification (SIC) codes. In 1997, this system was replaced by the North American Industrial Classification System (NAICS). However, as SIC codes are ubiquitous, the Department of Commerce maintains SIC-NAICS conversion tables on its website. SIC/NAICS codes function as keys unlocking vast stores of information housed in databases. This numbering system is referenced widely and provides a fairly easy way to cut through vast amounts of data. Given that you are working with fairly new technologies, you may not be able to find a SIC/NAICS code that exactly fits your specialty. You may have to move up to a broader class. For example, if your product is a warm suit, you would not expect to find a SIC/NAICS for this one-of-a-kind product. However, a warm suit is an example of protective clothing, emergency gear, or outerwear. You could start by looking for a SIC/NAICS code to cover this broader category. 


\section{WORKSHEET: ACTIVITY 12: MARKET GROWTH}

DATE

INSTRUCTIONS:Use the space below to compile information related to the rate of market growth. Add additional sheets as required.

(1) What is the appropriate SIC/ NAICS Code? Verify your selection by comparing it with that used by known competitors.

(2) Contact industry experts associated with the Department of Commerce and/ or with appropriate Associations to determine if they collect information by that SIC. Ask if they have collected information on future market projections for the SIC in question.

(3) Find another company that is approximately five years older than yours within the same industry. As a sensitivity check, benchmark rate of ramp up for them. 


\section{Competitors}

Related Activities:

Activity $13 \mathrm{a}$ and $13 \mathrm{~b}$ :

Who are Your Competitors?

Activity 14:

Implications of

Competitor Information 
The activities in this area of the Workbook (Activities 13 - 14) are to help you compile information about your competitors and consider the implications of this information for your commercialization strategy and business plan. 


\section{Who are the competitors in this market?}

Every company has competitors that are already operating within the market segment of interest. Your resources and skills relative to the other players will affect how profitable your business will be.

\section{Activities and background}

Various resources can be consulted to determine who your competitors are. The most common include the following:

1. Industry journals, local newspapers, customers, suppliers, and trade associations.

2. The Thomas Register of American Manufacturers is a large comprehensive set owned by most major libraries. It is updated annually, and lists manufacturers' names, addresses, and phone numbers. Information is organized alphabetically by product. This is an excellent starting place.

3. Ward's Business Directory of US Private and Public Companies provides a listing of the public companies with largest sales sorted by SIC/NAICS code.

4. Dialog: When looking for more obscure information and/or information on a global basis, Dialog is extremely useful. This searching process can be expensive.

5. High-Tech Directory: This resource lists over 800 publicly-traded companies specializing in innovative technology. To obtain a list, contact:

Barrington Research Associates

P.O. Box 860

Barrington, IL 60010

(708) 382-7788

\section{Have I answered this question adequately?}

Process: Examine the preceding references for information on competitors and begin to develop competitive files on each.

Results: The goal is a list of major competitors, including company name, address, and phone number. Group these by SIC/NAICS codes. 


\section{WORKSHEET: ACTIVITY 13A: COM PETITORS}

DATE

INSTRUCTIONS: Use the summary sheet below to compile information on competitors. Add additional pages as needed.

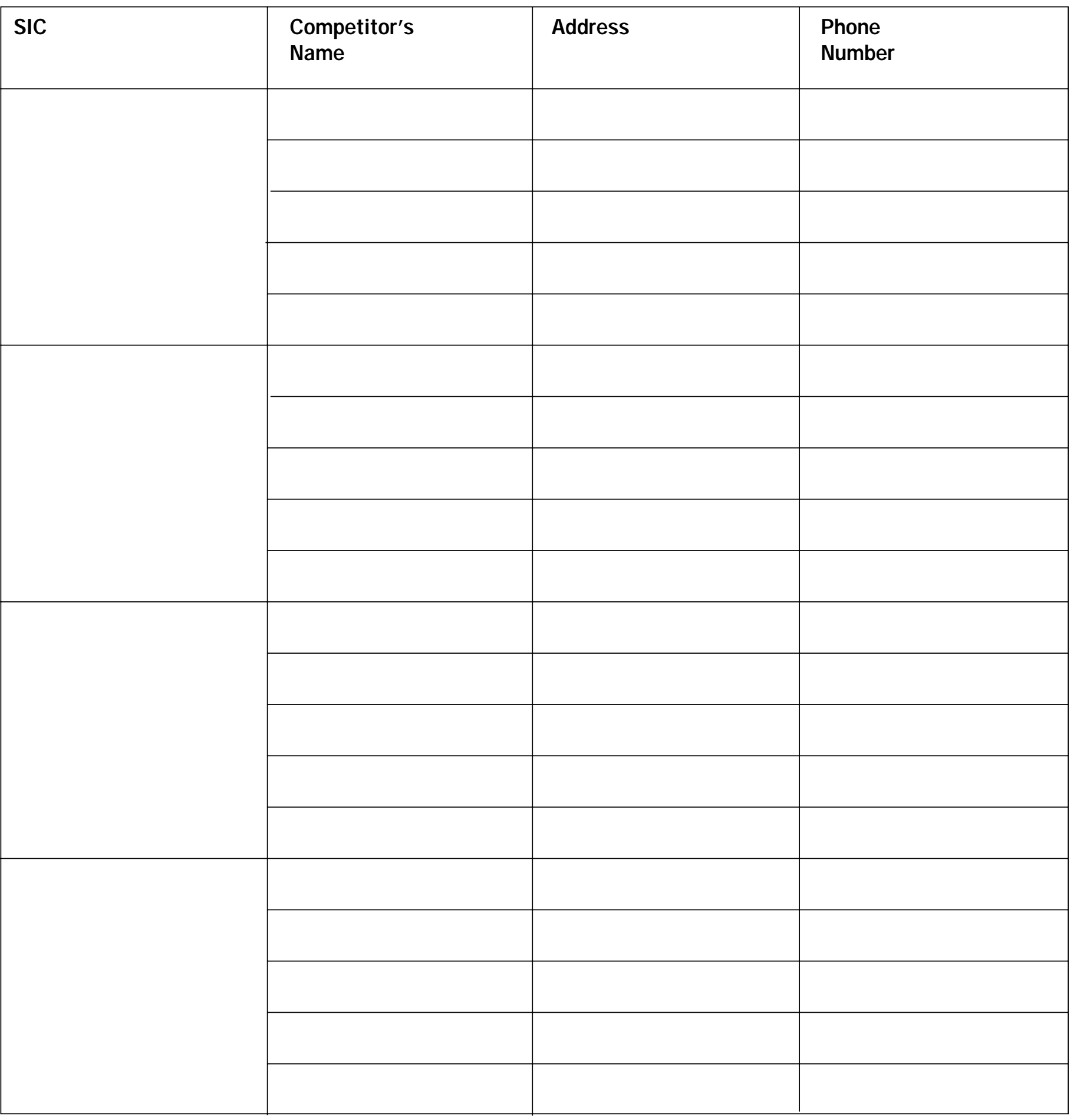




\section{What are the current characteristics of these competitors?}

This activity relates to expanding your customer files. In Activity 13a, you were asked to pinpoint who your competitors are. This activity helps you determine what types of information you should collect about your competitors. Analyzing your competitors' strengths and weaknesses helps you to take a more realistic look at your own organization and develop sound strategies for success.

\section{Activities and background}

The information you can obtain on competitors depends to a large extent on whether they are privately owned or publicly traded. Considerably more information is available on publicly traded companies. Leonard Fuld's book Monitoring the Competition (1988) provides many helpful hints on how to build up good data files on your competitors.

If the company is publicly owned, you can request an annual report, 10-K, 8-K, and 10-Q, from the Securities Exchange Commission. If the company is privately owned, the task is more difficult. However, you can develop good data from news articles, product literature and catalogs, price lists, and market studies, all of which may be available on the Web.

All of this information should be compiled in competitor files.

\section{Have I answered this question adequately?}

Process: Obtain more complete data on your competitors, in accordance with the suggestions listed above. In subsequent chapters you will be instructed to analyze the data you are now beginning to collect.

Results: The goal is a list of the competitor files that you have and what data your files contain: $10-\mathrm{K}, 8-\mathrm{K}, 10-\mathrm{Q}$, prospectus, annual reports, news articles, product literature, catalogs, price lists, and market studies. 


\section{WORKSHEET: ACTIVITY 13B: COM PETITORS}

DATE

INSTRUCTIONS: : Use the summary sheet below to act as both a prompt and a place to compile information regarding competitors. Much more information is available for publicly traded companies. Add additional pages as needed.

Competitor Name

Public?

Private?

\section{Prospectus}

$10 \mathrm{~K}$

$10 \mathrm{Q}$

$8 \mathrm{~K}$
Annual Report

Price Lists

Market studies

Newspaper clippings
Articles

Catalog

Internet info

Patents

Competitor Name

Public?

Private?
Prospectus
$10 \mathrm{~K}$
$10 Q$
$8 \mathrm{~K}$

Competitor Name

Prospectus

$10 \mathrm{~K}$

$10 \mathrm{Q}$

$8 \mathrm{~K}$
Annual Report

Price Lists

Market studies

Newspaper clippings
Articles

$\square$ Catalog

$\square$ Internet info

$\square$ Patents
Public?

Private?

Annual Report

Articles

Price Lists

Market studies

Newspaper clippings $\square$ Catalog

$\square$ Internet info

$\square$ Patents

\section{Competitor Name}

Public?

Private?

Prospectus

$10 \mathrm{~K}$

$10 \mathrm{Q}$

$8 \mathrm{~K}$
Annual Report

Price Lists

Market studies

Newspaper clippings
Articles

$\square$ Catalog

$\square$ Internet info

$\square$ Patents

Competitor Name

Public? Private?

Prospectus

$10 \mathrm{~K}$

10Q

$8 \mathrm{~K}$
Annual Report

Price Lists

Market studies

Newspaper clippings $\square$ Articles

$\square$ Catalog

$\square$ Internet info

$\square$ Patents 


\section{Implications of Competitor Files}

The purpose of developing good competitor files is to anticipate what your competitors are likely to do when you enter the marketplace with a new product that eats away at their market share. At the point of market entry, chess or war analogies are often used. It is important to keep in mind that the purpose of making a product entry is to gain market share and create value. This is always done at another company's expense. Some company will lose market share as you gain. Even in those instances where you come to market first and are developing a market, your presence in the marketplace first often makes it more difficult for other companies to replace you.

Once you have gathered competitor files, review the information looking specifically at issues such as the following:

- how financially stable your competitors are

D what their pricing policies have historically been

D their research and development plan

D strategic alliances formed

D distributors used

Then ask yourself what your competitors are likely to do when you enter the marketplace-drop their price, increase advertising, enhance customer service, buy a competitor to gain greater access to the marketplace, etc. Use this information when developing your marketing and sales plans, and your contingencies-all of which are part of your business plan. 


\section{WORKSHEET: ACTIVITY 14: IM PLICATIONS OF COM PETITOR FILES}

DATE

INSTRUCTIONS: This worksheet contains a list of prompts for you to use when reviewing competitor files. We have seen so many companies just collect information and never do anything with it. Set aside time for your management team to review competitor files and discuss the implications for your evolving strategies and business plan. Add additional pages as needed.

Competitor

Financial stability of competitor:

Pricing policy:

Research and development plan:

Strategic alliances formed:

Distributors used:

Other: 


\section{Conclusion}

The purpose of the Advanced Technology Program's Commercialization and Business Planning Guide for the Post-Award Period is to provide assistance to new ATP awardees and their advisors. The book is divided into three sections. Section 1 presents basic concepts concerning financing options, with detailed information on licensing, corporate partnering, and equity investment. Section 2 is an annotated sample presentation to investors. Section 3 is a workbook to be used by the technology entrepreneur on his own or with the guidance of an experienced advisor. For maximum benefit, it is recommended that you seek the involvement of an experienced and motivating mentor. The results of the various activities completed should be synthesized and incorporated into a variety of documents that become part of your Commercialization Toolkit ${ }^{\mathrm{TM}}$. Suggested outlines for the various documents that you are likely to need in the commercialization of your technology are included at the end of various chapters in Section 1 and throughout Section 2. These include:

- Strategic plan

- Licensing package

- Business plan

D Presentation

Scientists and engineers who are founders of their own companies can develop the necessary skills to successfully guide the growth of their firms. This requires dedication, however, since time for planning must be added to an already busy schedule. The information and the activities included in this workbook will assist in this endeavor. 


\section{Section 4}

INDEX AND B IBLIOGRAPHY 
A

ACE-Net, 95

Advanced Technology Program (ATP), 5-7

B

Borrowing

- from family and friends, 24

- from banks, 24

Bridge financing, 31

Business angels, 29

Business Opportunity Preview, 79-80

Business plan, 102

- Distribution protocols, 112

- Getting feedback on the draft, 110

- Revising the plan, 111

- Scope, 102

- Difference between business plan and prospectus, 103

- Using the business plan, 112

Business plan outline (Detailed), 106-109

Business plan outline (General), 105

Buyer behavior, 226

C

Cashing out, 33

Commercialization strategy, 37, 209

Corporate partnering, 85

Customers, 224

D

Debt financing, 22

Distribution agreement, 86

Downstream applications, 50
$E$

Early stage financing, 31

End-users, 224

Equity financing, 27

Equity investment in parent company, 42

Equity investment in spin-off, 43

Executive summary, 110

Exit scenarios, 33

External value of business plan

\section{$\mathrm{F}$}

Features, Advantages, \& Benefits, 222

Factor, 25

Foundation company, 17

$\mathrm{H}$

High-potential venture, 17, 18

I

Industry experts, 219

Initial Public Offering (IPO), 27, 30, 45, 100

Institutional venture capital, 29, 96

Intellectual property, 198

Internal value of business plan, 114

Interviews, 220

Investment bankers, 27

J

Joint ventures, 88 
$\mathrm{L}$

Leasing, 26

Leveraged buy-out, 32

Licensing, 63

Licensing-in, 64

Hybrid licensing agreement, 71

Multimedia license, 71

Product license, 70

Software license, 72

Licensing with developmental funds, 38

Licensing package, 79

Licensor, 70

Licensor title, 66

Life-style firm, 17

M

Manufacturing Agreement, 87

Market build-up method, 236

Market growth, 246

Market segmentation, 234

Market size, 242

Mass markets, 231

Mezzanine financing, 31

Mission, 204

$\mathrm{N}$

Negotiation issues, 84

Niche markets, 231

P

Personal philosophies, 37

Presentation materials, 117

Private placements, 27

Provisional patent application, 198
$\mathrm{R}$

R\&D Agreement, 86

Receivable lending institutions, 25

Regulation D, 97

Return on Investment, 33

Royalty rates, 69

S

Securities Exchange Act of 1933, 97

Seed financing, 31

Small Business Innovation Research, 21

Start-up financing, 31

Strategic alliances, 40, 86, 206

Strategic fit, 64

Strategic plan, 55

Supplier credit, 27

Sweat equity, 19-20

Sustainable competitive advantage, 49, 200

T

Technology partitioning, 53

U

Upstream applications, 50

$\mathrm{V}$

Venture capital, 96

Vision, 202 


\section{BIBLIOGRAPHY}

Abernathy, W.J. and Utterback, J.W. Patterns of Industrial Innovation.

Technology Review. January/July 1978. Vol 80, Issue 7, pp. 40-47.

Andonian, Joseph. Environment Changing in Pharmaceuticals. Les Nouvelles, Vol 24,

No 2.

Arkebauer, James. The Entrepreneur's Guide to Going Public. Dover, New Hampshire: Upstart Publishing Company, 1991.

Badaracco, Jr., Joseph L. The Knowledge Link:How Firms Compete through Strategic Alliances, Boston: Harvard Business School Press, 1991, p.4.

Barrett, E. Thorpe. Write Your Own Business Contracts: What Your Attorney Won't Tell You. Grants Pass: The Oasis Press, 1994.

Bianchi, Alessandra. Learning to Live with (or Without) Your Banker. Inc, March 1995, pp. 32-42.

Blechman, Bruce and Levinson, Jay Conrad. Guerrilla Financing: Alternative Techniques to Finance and Small Business. Boston: Houghton Mifflin Company, 1991.

Epstein, Michael A and Politano, Frank L. Drafting Licensing Agreements. Englewood Cliffs, NJ: Aspen Publishers, 1995.

Fordis, Jean Burke and Griffen, Susan Heberman. Avoiding Traps in Licensing Biotechnology . Les Nouvelles. Vol 26 No 2.

Garner, Daniel; Owen, Robert, and Conway, Robert. The Ernst \& Young Guide to Financing for Growth. New York: John Wiley \& Sons, 1994.

Goldscheider, Robert. Companion to Licensing Negotiations: Licensing Law Handbook 1993-94. Deerfield, Il: Clark, Boardman, Callaghan, 1993.

Greeley, Paul D. Effective License Negotiating Techniques. Les Nouvelles. Vol 25 No 1. 
Hamel, Gary; Doz, Yves, L.; and Prahalad, C.K. "Collaborate with Your Competitors—and Win," Harvard Business Review, January-February, 1989, pp. 133-139.

Hanan, Mack. Growth Partnering: How to build your company's profits by building customer profits, Anacom, 1992.

Harrigan, Kathryn Rudie. Strategic Alliances: Their New Role in Global Competition. Columbia Journal of World Business, 22.2 (Summer, 1987), pp. 67-69.

Hess, Robert P. Desk Book for Setting Up a Closely Held Corporation. Englewood Cliffs: Institute for Business Planning, 1985.

Heuss, Valentin and Jolly, Vijay. Commercializing Multifaceted Technologies. Les Nouvelles. Vol 25.No 2.

Hisrich, Robert D. and Peters P., Michael. Entrepreneurship: Starting, Developing, and Managing a New Enterprise. Homewood, IL: BPI, 1989.

Linneman, Robert E. and Stanton, Jr., John L. Making Niche Marketing Work. New York: McGraw-Hill, 1991.

Manfroy, Willy, Patterson, William and Staackmann, Joachim. Technology Acquisition Process. Les Nouvelles. Vol 24 No 4

Ohmae, Kenichi. The Global Logic of Strategic Alliances. Harvard Business Review, March-April, 1989, pp. 143-155.

Parr, Russell L. Insights Into Royalty Rate Economics. Les Nouvelles, Vol 25.No 2

Poole, Shiela M. New Biotech Venture: Project could spur flow of venture capital incubator's program part of plan. The Atlanta Constitution; Atlanta, GA, August, 14, 1998.

Radcliffe, Mark F and Clowes, Howard. Issues in Strategic alliances. Les Nouvelles. Vol 26, No 3.

Raising Capital: How to Borrow from Family and Friends. Inc. July, 1995, p 99.

Ries, Al and Trout, Jack. Positioning: The Battle for Your Mind, New York: Warner Books, Inc., 1981. 
Sandhusen, Richard L. Marketing. Barron's Educational Series, Inc.

New York, 1987.

Servo, Jenny. Business Planning for Scientists and Engineers. Rochester, NY, Dawnbreaker Press, 1999.

Servo, Jenny. Developing Indicators of Commercial Potential. Rochester, NY, Dawnbreaker Press, December 1995.

Servo, Jenny \& Hauler, Paul. Knock their Socks Off: Making Winning

Presentations to Investors. Rochester, NY, Dawnbreaker Press, 1993.

Smedinghoff, Thomas J. Multimedia Legal Handbook: A Guide from the Software Publishers Association. New York, NY, Aspen Law and Business, 1998.

Swisher, Kara. Venture Capital Investments Surged to High in Quarter. Wall Street Journal, New York, August 17, 1998.

Taylor, James W. Competitive Marketing Strategies: An action plan for achieving market leadership. Radnor, PA: Chilton Book Co., 1986.

Teece, David. Capturing value from Innovation . Les Nouvelles. Vol 26, No 1.

Thomsett, Michael C. The Little Black Book of Project Management. Amacom, 1990.

Tuller, Lawrence W. The Small Business Valuation Book. Holbrook, MA: Adams Media Corporation, 1994

U.S. Bureau of the Census, Statistical Abstract of the United States:

1994 (114th edition.) Washington, DC, 1994.

Villeneuve, Thomas F, Gunderson Jr., Robert V., and Kaufman, Daniel M.

Corporate Partnering: Structuring and Negotiating Domestic and International Strategic Alliances. Aspen Law \& Business, 1995.

Webster, Frederick. Market-Driven Management: Using the New Marketing Concept to Create a Customer-Oriented Company. New York: John Wiley \& Sons, 1994.

Wetzel,William and Hughes, Frank. 1989 SBIR Conference presentation. Washington, DC, 1989. 